UNIVERSIDADE DE SÃO PAULO

FACULDADE DE FILOSOFIA, LETRAS E CIÊNCIAS HUMANAS

DEPARTAMENTO DE HISTÓRIA

PROGRAMA DE PÓS-GRADUAÇÃO EM HISTÓRIA SOCIAL

RODRIGO FERNANDO GALLO

\title{
HERÓdOTO E A TEORIA DAS FORMAS DE GOVERNO: O DEBATE CONSTITUCIONAL PERSA
}


UNIVERSIDADE DE SÃO PAULO

FACULDADE DE FILOSOFIA, LETRAS E CIÊNCIAS HUMANAS

DEPARTAMENTO DE HISTÓRIA

PROGRAMA DE PÓS-GRADUAÇÃO EM HISTÓRIA SOCIAL

\title{
HERÓdOTO E A TEORIA DAS FORMAS DE GOVERNO: O DEBATE CONSTITUCIONAL PERSA
}

\author{
Rodrigo Fernando Gallo \\ Dissertação apresentada à Faculdade de \\ Filosofia, Letras e Ciências Humanas da \\ Universidade de São Paulo para a obtenção do \\ título de mestre em História Social.
}

Programa de Pós-Graduação em História Social

Orientador: Prof. Dr. Marcelo Rede

São Paulo

2015 
Autorizo a reprodução e divulgação total ou parcial deste trabalho, por qualquer meio convencional ou eletrônico, para fins de estudo e pesquisa, desde que citada a fonte.

Catalogação na Publicação

Serviço de Biblioteca e Documentação

Faculdade de Filosofia, Letras e Ciências Humanas da Universidade de São Paulo

Gh

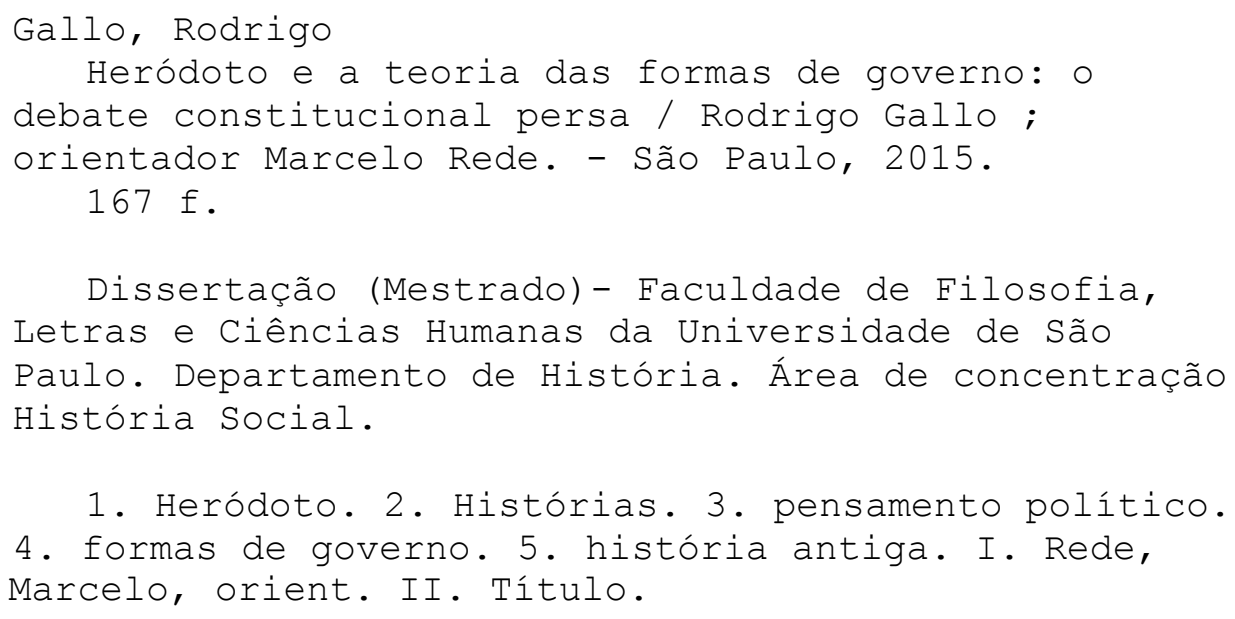

1. Heródoto. 2. Histórias. 3. pensamento político. 4. formas de governo. 5. história antiga. I. Rede, Marcelo, orient. II. Título. 
Nome: GALLO, Rodrigo Fernando.

Título: Heródoto e a teoria das formas de governo: o debate constitucional persa

Dissertação apresentada à Faculdade de

Filosofia, Letras e Ciências Humanas da

Universidade de São Paulo para a obtenção do título de mestre em História Social.

Programa de Pós-Graduação em História Social

Orientador: Prof. Dr. Marcelo Rede

Aprovado em:

\section{Banca examinadora}

Prof. Dr.:

Instituição:

Assinatura:

Prof. Dr.:

Instituição:

Assinatura:

Prof. Dr.:

Instituição:

Assinatura: 


\section{Resumo}

O objetivo desta dissertação é investigar o fragmento III.80-82 das Histórias, no qual Heródoto narra um debate entre três nobres persas, ocorrido em 522 a.C.. O que estava em discussão era a melhor forma de governo a ser adotada pela Pérsia após a morte do usurpador Smérdis. No chamado debate persa, Otanes propôs a adoção de uma constituição democrática, Megabizo sugeriu a instituição de uma oligarquia, e Dario, por fim, defendeu a manutenção da monarquia - a ideia que venceu o debate. Nossa proposta é analisar a construção de um pensamento político nas Histórias, com o suporte da filosofia política, de modo a demonstrar que o autor pode ser classificado como um pensador político não-sistemático. Além disso, esse estudo demonstra a possibilidade da leitura do documento indicar a existência de seis formas de governo, sendo três constituições boas, e suas três versões degeneradas.

Palavras-chave: Heródoto; Histórias; pensamento político; formas de governo; história antiga. 


\begin{abstract}
The objective of this study is investigate about the fragment III.80-82 of Herodotus' Histories, in which the author describes a debate between three noble Persians, in 522 B.C.. They have been discussing the best form of government to be adopted in Persia after the death of Smérdis the usurper. In the Persian debate, Otanes proposed a democratic constitution, Megabyzus suggested an oligarchy, and after then Darius defended the maintenance of the monarchy - the idea such win the debate. Our goal is to analyze the construction of a political thought in Histories, with the support of political philosophy, to show the author can be considered as a political thinking nonsystematized. Besides, this work demonstrates a possibility to understand the document like a scheme of the six forms of government, with three good constitutions, and another three its bad versions.
\end{abstract}

Keywords: Herodotus; Histories; political thinking; forms of government; ancient history. 


\section{Résumé}

L'objectif de cette étude est étudier le fragment III.80-82 des Histoires, dans Hérodote relate um débat entre trois nobles Perses, qui a eu lieu en 522 J.C.. Ils ont discuté de ce qui était la meilleure forme de gouvernment pour être adopté par la Perse après la mort de l'usurpateur Smérdis. Otanes a proposé l'adoption d'une constitution démocratique, Mégabyze a suggéré la création d'une oligarchie, et Dario finalement a défendu la monarchie - l'idée qui a gagné le débat. Notre objectif est analyser la construction d'une pensée politique dans les Histoires, avec l'aide de la philosophie politique, afin de démontrer que l'auteur peut être classifiqué comme un penseur politique nonsystematiqué. Cette étude démontre ainsi la possibilité de document indiquer l'existence de six formes de gouvernment, trois bonnes constitutions, et ses trois versions dégénérées.

Mot clés: Hérodote; Histoires; pensée politique; formes de gouvernment; histoire anciénne. 


\section{Agradecimentos}

Escrever uma lista de agradecimentos é uma tarefa delicada. O motivo é simples: muitas pessoas contribuíram, direta ou indiretamente, para a conclusão desta jornada. Algumas dessas contribuições, inclusive, pertencem a um passado distante, muito anterior à minha chegada no Departamento de História Social da Universidade de São Paulo. Deste modo, uma lista completa de agradecimentos seria impossível - e certamente deixaria alguém de fora. Logo, a melhor maneira de não incorrer em nenhuma injustiça é agradecer, neste espaço, apenas às principais pessoas que acompanharam e contribuíram para o término desta etapa de minha vida.

$* * * * *$

Assim, devo agradecer primeiramente as pessoas mais importantes nesta trajetória; aquelas pessoas que estão (ou estiveram) ao meu lado no dia a dia, que me deram suporte para a superação de todas as adversidades e que acreditaram nas minhas capacidades: à minha esposa, Jamille, obrigado pelo amor, pela paciência e por não me deixar desistir nas horas mais sombrias; aos meus pais, Wagner e Cida, sem os quais nada disso faria sentido; às minhas avós, Humbelina e Lourdes, pelo carinho e pela dedicação; e aos meus avôs, Walter e Januário, que me ensinaram a sonhar. Obrigado por tudo. Essa dissertação é dedicada a vocês!

Também agradeço a alguns amigos que encontrei na USP e que estiveram comigo em diversos momentos dessa trajetória: Alan Nicolaev, Helmut Steinwascher e Lúcia Cutro, obrigado pelos comentários, críticas e sugestões que ajudaram a melhorar esse estudo; Luiz Henrique Souza de Giacomo, agradeço pelos longos debates sobre política no mundo Antigo e por toda a ajuda, principalmente na etapa final deste trabalho.

Agradeço imensamente aos professores que contribuíram direta ou indiretamente para a realização deste estudo, com suas valiosíssimas sugestões e críticas durante aulas inesquecíveis no Departamento de História Social: Julio Cesar Magalhães de Oliveira, Laura de Mello e Souza, Norberto Luiz Guarinello e Maria Luiza Corassin. 
Agradeço, ainda, aos professores Breno Battistin Sebastiani e, novamente, ao professor Julio Cesar, pelas valiosas críticas no exame de Qualificação, essenciais para o aperfeiçoamento metodológico deste estudo.

Agradeço ao professor Carlos Augusto Ribeiro Machado, que supervisionou meu estágio docente no Departamento de História: obrigado pela oportunidade, pela confiança e por todo o incentivo acadêmico.

Agradeço aos funcionários do Departamento de História, pela presteza e pelas orientações, e aos funcionários das bibliotecas da Faculdade de Filosofia, Letras e Ciências Humanas (FFLCH), Faculdade de Educação e do Museu de Arqueologia e Etnologia (MAE), por facilitarem a realização de minhas pesquisas.

Agradeço aos meus alunos, que me ensinaram a aprender.

Agradeço a alguns professores que encontrei ao longo do caminho, em épocas distintas: Aldo Fornazieri, Flávio Rocha, Paulo Levorin e Vitor Marchetti.

Agradeço aos companheiros de longa data: Robson e Nincao (expedição Egito!), Fabio, Leandro, Léo, Nadir, Saulo e Yuri.

Por fim, agradeço, em especial, o empenho do meu orientador, professor Dr. Marcelo Rede, que me auxiliou a superar essa árdua jornada, sempre disposto a discutir, a questionar e a corrigir os meus erros, e por não permitir que eu me conformasse com as respostas mais simples. 
Esse trabalho é dedicado à minha esposa, Jamille, aos meus pais, Wagner e Cida, e a algumas pessoas especiais que não estão mais conosco. 
“Creso”, disse Sólon, “você me pergunta sobre a sorte dos homens; bem, eu conheço como os deuses são ciumentos e como eles gostam de nos incomodar. No curso de uma longa vida podemos ver muitas coisas de que não gostamos, e também podemos sofrer muito. (...) Então, Creso, o homem é apenas vicissitudes. Agora, se estou falando com você, eu digo que me parece ser um homem muito rico e rei de muitos homens. Mas eu ainda não posso responder à sua pergunta antes de saber que você também terminou bem a sua vida."

(Heródoto, Histórias, I.32) 
Esse é um princípio justo: não é possível ser um bom comandante sem primeiro aprender a obedecer. Não que o governo e a obediência virtuosos sejam a mesma coisa. Mas o cidadão virtuoso precisa ter o conhecimento e a habilidade tanto de governar como de ser governado. É isso que entendemos por virtude de um cidadão: entender o governo de homens livres por homens livres.

(Aristóteles, Política, III.4.17) 


\section{Lista de abreviações}

AHR: The American Historical Review

AI: Acta Iranica

AJP: American Journal of Philology

APA: American Philological Association

Const. At.: Constituição de Atenas (Aristóteles)

Db.: Inscrição de Behistun (Dario)

Hist.: Histórias (Heródoto)

Hist.: Histórias (Políbio)

JHS: The Journal of Helenic Studies

JNES: Journal of Near Eastern Studies

JPS: Journal of Persianate Studies

Pelop.: História da Guerra do Peloponeso (Tucídides)

Pol.: Política (Aristóteles)

Pyth.: Pítias (Píndaro)

QS: Quaderni di Storia

QUCC: Quaderni Urbinati di Cultura Classica

PCPhS: Proceeding of the Cambridge Philological Society

REG: Revue d'Études Grecques

Rep.: República (Platão)

RCSP: Revue Canadienne de Science Politique

USP: Universidade de São Paulo 


\section{Lista de quadros}

Quadro 1: Lógoi das Histórias 48

Quadro 2: Teoria positiva e teoria negativa ...................................................................... 140

Quadro 3: Posse e uso do poder 141

Quadro 4: As formas de governo no debate persa $141-142$ 
Lista de figuras

Figura 1: Inscrição de Behistun 


\section{Sumário}

Introdução .............................................................................................................................. 18

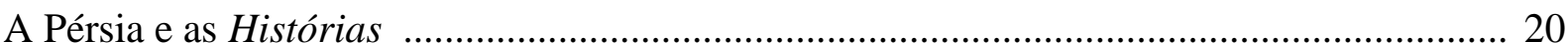

Contexto: o usurpador, a conspiração e a ascensão de Dario ................................................. 22

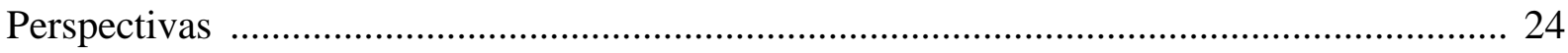

Estrutura da dissertação ........................................................................................... 27

Capítulo 1: Heródoto e a escrita das Histórias ........................................................................... 31

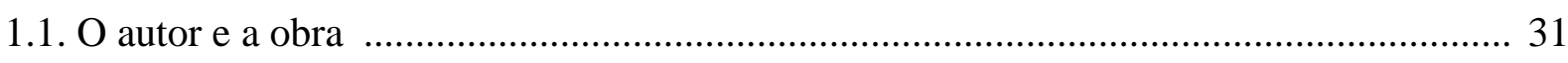

1.2. Narrativa de viagem ....................................................................................... 35

1.3. O estatuto histórico das Histórias …………………………………………………... 40

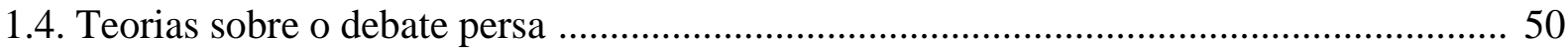

Capítulo 2: O pensamento político nas Histórias ................................................................... 64

2.1. Reflexões sobre o pensamento político na obra de Heródoto .......................................... 64

2.2. O governo de um nas Histórias ......................................................................... 72

2.3. O governo da maioria nas Histórias ......................................................................... 83

2.4. O governo de poucos nas Histórias ……………………………………………..... 95

Capítulo 3: A teoria política sobre o debate persa ................................................................. 105

3.1. Introdução ao debate persa .................................................................................... 105

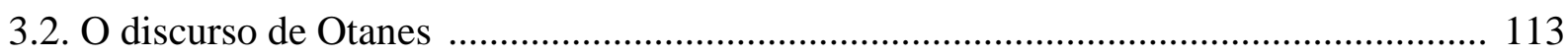

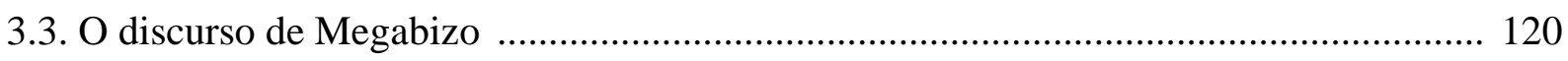

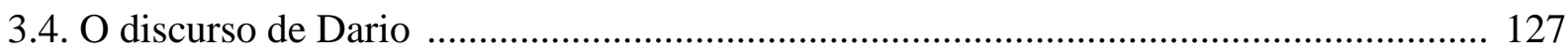

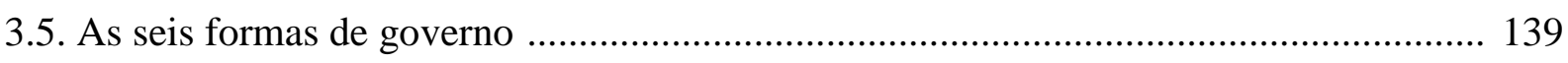

Considerações finais .................................................................................................................... 145

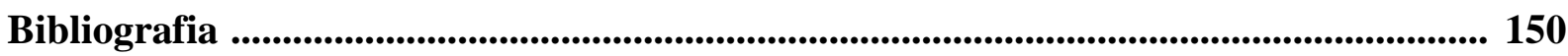

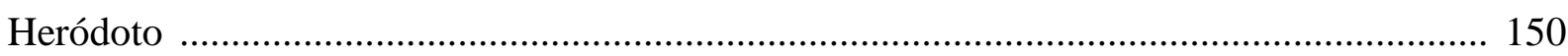

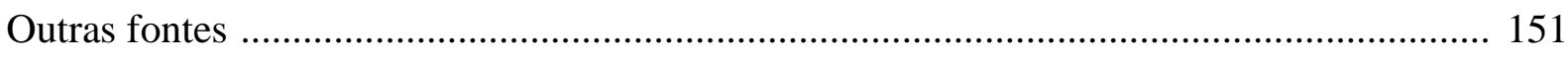

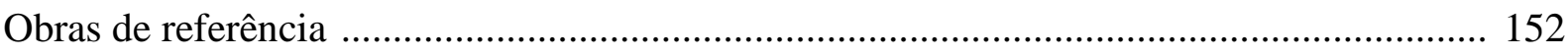

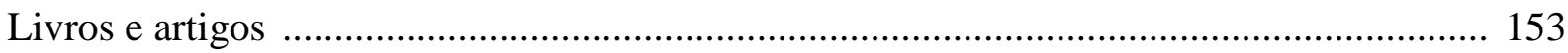




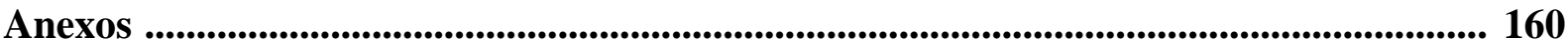

Anexo A - Edição Les Belles Lettres ............................................................................... 160

Anexo B - Edição The Loeb Classical Library ..................................................................... 163

Anexo C - Edição UnB (tradução de Mário da Gama Kury) ............................................. 165 


\section{Introdução}

A compreensão da obra de um historiador da Antiguidade, como Heródoto, sofre inúmeras modificações e interpretações ao longo das décadas. Isso ocorre porque o tempo transforma as linhas de pensamento a respeito da ciência histórica, alterando a forma como lemos e interpretamos os textos clássicos. Deste modo, um assunto já muito pesquisado, como o debate persa (Hist., II.80-82), pode ser constantemente revisitado e, ainda assim, oferecer novas possibilidades de abordagem sobre a discussão acerca das formas de governo.

Embora o tempo tenha mudado a compreensão sobre essa passagem, há pelo menos um ponto em comum entre os mais diversos estudos, sejam eles antigos, datados da primeira metade do século passado, ou contemporâneos, realizados principalmente nos últimos 20 anos: o fato de que este é um dos trechos mais polêmicos das Histórias (MENESES SOUSA, 2010: 15).

A controvérsia existe porque, segundo Heródoto, em 522 a.C., logo após o assassinato de um suposto usurpador do trono persa, sete conspiradores se reuniram para decidir o futuro político da Pérsia. Três deles teriam protagonizado um debate sobre as formas de governo. Dario propôs a manutenção da monarquia. Megabizo defendeu a adoção de um governo oligárquico, no qual eles mesmos fariam parte. Otanes, por sua vez, sugeriu a criação de um governo popular, que garantisse a isonomia e acabasse com os abusos cometidos pelos governantes em regimes monárquicos.

O fato de um persa ter mencionado a democracia, de acordo com a narrativa herodotiana, é visto como um problema por muitos autores. O próprio Heródoto admitiu que os discursos relatados no fragmento causariam espanto entre os gregos (Hist., III.80). O modelo democrático, defendido por Otanes, seria uma forma de governo estranha à realidade da Pérsia, cuja tradição residia nas instituições monárquicas. Não bastasse isso, o primeiro exercício democrático devidamente documentado que nós conhecemos surgiria apenas em 508/507 a.C., em Atenas, com as reformas de Clístenes.

Sendo assim, há décadas os pesquisadores têm buscado formas de analisar o fragmento na tentativa de melhor compreendê-lo. E, nesse esforço, geração após geração de estudiosos busca formas distintas para interpretar o debate persa, resultando em estudos ora contraditórios entre si, ora limitados devido à escassez de fontes sobre o período e sobre a própria passagem. 
Tanto interesse pelo autor - e por esse fragmento do documento, especificamente - nos indica que Heródoto III.80-82 não é apenas um trecho controverso e passível de inúmeras possibilidades de interpretação. É, sobretudo, um trecho fundamental para a construção do pensamento político grego, que no tempo do historiador de Halicarnasso (e provavelmente antes dele também) já buscava um meio de entender o funcionamento das constituições e, com isso, as implicações inerentes à concentração e à distribuição de poder.

Heródoto não foi o primeiro grego a falar sobre o assunto. Em sua obra clássica, Ernest Baker dizia que as póleis construíam cidadãos cientes de sua individualidade, ou seja, capazes de compreender que cada cidade era autônoma - embora estivessem localizadas muito próximas umas das outras. Nesse sentido, o autor defende que esse cenário impulsionava a elaboração de comparações: os gregos começaram a "discutir o valor de cada um dos tipos distintos de estado", com o intuito de verificar qual era melhor (BAKER, 1978: 25-26).

Desta forma, acredita-se que a discussão sobre as formas de governo já era conhecida nas póleis antes da publicação das Histórias (SEALEY, 1973: 273; EVANS, 1981: 80; ROY, 2012). Provavelmente, era um assunto comum nas ágoras, principalmente se pensarmos que a política é o estudo da atividade de governar, que por sua vez depende de homens para o desempenho dessa tarefa: sejam eles monarcas ou tiranos (ZIMMERN, 1951: 323). Por conta disso, as constituições - e a forma como o governante administrava o estado - deviam ser temas importantes para os cidadãos.

A importância do assunto era tamanha que, mesmo antes de Heródoto ou dos filósofos políticos, a questão já era prenunciada por autores de outros gêneros, como Píndaro: ele teria sugerido implicitamente a discussão, distinguindo o governo de um homem, de poucos ou da maioria (SEALEY, 1973: 273). O autor, portanto, explicou numericamente a distinção, mas não apresentou as tipologias.

Deste modo, Heródoto foi o primeiro a elaborar o esboço de uma teoria das formas de governo, trabalhando com as nomenclaturas clássicas (BOBBIO, 1985: 39) que se tornariam referência para esse campo de estudos da teoria política e influenciariam os filósofos dos séculos seguintes, como os gregos Platão e Aristóteles, além de Políbio, Cícero e tantos outros, que se encarregariam de dar continuidade na discussão do tema - e sistematizar de fato essa discussão.

Se o debate de fato ocorreu conforme Heródoto nos relata (como vão questionar os positivistas), não nos importa. Importa, sim, que ele foi incluído nas Histórias, e isso 
por si só já causa uma série de desdobramentos, como a possibilidade de interpretarmos que o historiador construiu, no fragmento, um pensamento político não-sistematizado.

Mais do que narrar um diálogo entre nobres persas, podemos considerar que o historiador de Halicarnasso deixou como legado o princípio de um pensamento político que seria tão caro à tradição política do Ocidente - e cabe a nós, pesquisadores contemporâneos, buscar novas formas de compreender e interpretar o debate entre Otanes, Megabizo e Dario.

\section{A Pérsia e as Histórias}

Quando Heródoto escreveu suas Histórias, o império persa já era antigo. Ciro, o Grande, transformara a Pérsia em uma potência militar havia mais de cem anos. Suas terras, no tempo do historiador grego, se estendiam ao extremo leste para além das formações do Hindu Kush, e a oeste até a costa da Ásia Menor, a atual Turquia - cujo relevo era pontilhado por importantes póleis gregas jônias, como Halicarnasso e Mileto; ao norte, os persas dominavam territórios além do Ponto Euxino, chegando às planícies da Cítia, e ao sul, até as longínquas terras de etíopes e egípcios, onde a resistência à conquista estrangeira era constante. Era, portanto, um vasto território vivendo sob o domínio político de Susa.

A conquista começou quando Ciro libertara os persas do domínio medo, e, em seguida, marchou contra a Babilônia. Era o início de um longo processo de integração entre a Pérsia e os povos do Egeu, Anatólia e Mesopotâmia (ASHERI, 2006: 23), além de Síria, Assíria, Armênia e Capadócia (OLMSTEAD, 1948: 37).

Era também o início de uma política de expansão imperial, segundo a análise de Evans, iniciada pelo próprio Ciro e seguida por seus sucessores:

Primeiro, o expansionismo era uma lei persa, e não uma novidade. Era uma regra sancionada pelos céus e trouxe à Pérsia grandeza e prosperidade. Segundo, há o exemplo dos predecessores de Xerxes que também seguiram essa lei. Ciro, Cambise e Dario tinham anexado (terras) ao império, e então Xerxes deveria fazer o mesmo. (EVANS, 1991: 12). 
As conquistas, complementa o historiador italiano David Asheri, também foram importantes para criar as "bases do processo de amálgama do mundo assírio-babilônico e do mundo irânico" (ASHERI, 2006: 23). O novo império se construía a partir das bases dos impérios anteriores (GUARINELLO, 2013: 99), demonstrando, sob a perspectiva helênica, um caráter eminentemente expansionista (WARD, 2008: 65).

Diante deste cenário de expansão, os contatos entre gregos e persas eram inevitáveis no Mediterrâneo - sobretudo por conta da influência que Susa exercia sobre as cidades jônias. Essa integração resultou em dois grandes conflitos, que colocaram em choque dois modelos políticos diferentes. De um lado, as cidades-estado gregas, formações políticas independentes, restritas a pequenos territórios; do outro, um vasto estado integrado, que reunia sob seu governo diversos povos anexados com o passar do tempo e com um sistema político descentralizado, pelo qual os governantes locais resguardavam certa autonomia, porém, se reportando diretamente ao governo central em Susa (ASHERI, 2006: 46-47).

As Guerras Médicas marcaram a geração de Heródoto e compunham uma importante tradição acerca das tensas relações entre gregos e bárbaros. Por conta disso, quando as Histórias foram escritas e apresentadas ao público grego, parte das narrativas já era conhecida em territórios helênicos, sobretudo porque dizia respeito à glória militar ante os persas: os atenienses, orgulhosos, insuflavam a vitoriosa campanha de 490 a.C. em Maratona; espartanos, por sua vez, lembravam da bravura da resistência nas Termópilas e, depois, da grande batalha de Platéia, que culminou na derrota de Xerxes.

Em sua obra, o historiador procurou explicar a origem dos conflitos, e nesse processo ofereceu aos leitores detalhes sobre quem eram os invasores orientais, seus costumes e suas instituições políticas. É nesse contexto que Heródoto insere o debate persa (Hist., III.80-82), o momento no qual a manutenção da monarquia teria sido decidida por meio de uma discussão envolvendo três proeminentes membros da nobreza da Pérsia: Otanes, Megabizo e Dario. Novamente, é importante lembrarmos que este é um dos pontos mais controversos da obra herodotiana, por diversas razões. Uma delas é que os persas, para muitos autores, não tinham a tradição do debate, que seria um costume típico das cidades-estado (THOMPSON, 1996: 53). Além disso, a estrutura do próprio discurso em si seria típica da retórica grega, e não persa (MURARI PIRES, 2012: 183). 


\section{Contexto: o usurpador, a conspiração e a ascensão de Dario}

Podemos compreender o debate persa como um dos episódios presentes nas narrativas de origem e ascensão de Dario ao trono, que o retratam como um líder político habilidoso e responsável por restaurar a ordem na Pérsia - assim como Deioces havia feito com os medos tempos antes. A história do aquemênida está envolta em uma trama cujo principal fio condutor não parece ser a manutenção da monarquia, mas sim o restauro da dinastia (BRIANT, 2002: 109), que envolvia um suposto golpe de Estado e, posteriormente, uma conspiração para a derrubada do líder golpista.

Conta Heródoto que Cambises, o sucessor de Ciro, se afastou da Pérsia para combater os egípcios. Durante a campanha, o rei dos persas havia sonhado que seu irmão, Smérdis ${ }^{1}$, tomara-lhe o trono. Temendo que o presságio se concretizasse, Cambises ordenou que o irmão fosse executado preventivamente e, assim, o perigo afastado (Hist., III.30) ${ }^{2}$. A missão foi cumprida por um fiel servo do rei. O assassinato foi mantido em sigilo, mas dois magos ${ }^{3}$, que estavam em Susa, sabiam do ocorrido. Um deles era o administrador do palácio real. O outro, coincidentemente, também se chamava Smérdis e era inclusive parecido com o irmão morto de Cambises.

A dupla, então, arquitetou um plano para tomar o trono da Pérsia. Smérdis - o mago - reivindicou o título de rei, e arautos foram despachados para todos os cantos do império levando a notícia de que Cambises não era mais o governante (Hist., III,61). Ao ser informado do golpe de Estado pelos mensageiros, o rei legítimo, que nesse momento estava em Ecbátana, decidiu reagir. Porém, Cambises feriu gravemente a própria coxa com a espada quando montou no cavalo (Hist., III.64), e morreria pouco depois, em decorrência desta lesão.

Heródoto, com isso, narra ao leitor que um grave problema dinástico se abateu sobre a Pérsia, uma vez que o rei legítimo havia morrido sem deixar herdeiros, e um suposto usurpador ocupara ilegitimamente o trono. O reinado do mago, no entanto, durou pouco. Durante sete meses ele governou sem enfrentar problemas (Hist., III.67),

\footnotetext{
${ }^{1}$ Segundo Olmstead (1948: 92) e Briant (2002: 98), o nome persa do irmão de Cambises era Bardiya. Ele era chamado de Smérdis pelos gregos, que também o conheciam por vários outros nomes, como Mardos, Maruphius, Merphis, Tanaoxares, Tanyoxarces e Mergis. O nome varia de acordo com o autor que escrevia sobre o irmão de Cambises.

${ }^{2}$ No fragmento, Heródoto conta que uma versão indica que Smérdis foi morto em Susa por Prexapes, durante uma caçada. Outra versão indica que o irmão de Cambises foi afogado (Hist., III.30).

${ }^{3}$ Os magos compunham um dos povos anexados ao império persa.
} 
até que no oitavo mês Otanes descobriu a farsa ${ }^{4}$ (Hist., III.68-69) e deu início à conspiração que derrotaria Smérdis.

Segundo o documento, Otanes convocou dois persas de sua confiança, Aspatines e Góbrias, e contou-lhes a história por trás da coroação do mago. Três outros nobres foram convidados a integrar a conspiração: Intafernes, Megabizo e Hidarnes. Dario chegou na sequência e foi incluído no grupo (Hist., III.70). Heródoto simplesmente diz que ele chegou e juntou-se aos conspiradores (MENESES SOUSA, 2010: 43), sem dar detalhes. Desta forma, não é possível saber com exatidão se Dario tinha como objetivo executar o inimigo e tomar o poder sozinho, sem a ajuda de nenhum outro persa, ou se pretendia encontrar auxílio. De qualquer forma, os sete se uniram, tomaram as decisões necessárias e foram a Susa combater o usurpador.

De acordo com Heródoto, os conspiradores invadiram o palácio e combateram os magos numa luta corpo a corpo. Aspatines foi ferido na coxa, e Intafernes no olho. Góbrias e Dario perseguiram o usurpador, e coube ao aquemênida executar Smérdis com um punhal (Hist., III.78). Derrotados, os magos tiveram as cabeças decapitadas e a dinastia finalmente poderia ser restaurada.

A versão apresentada por Dario na Inscrição de Behistun usa basicamente os mesmos argumentos, porém, difere em alguns detalhes. De acordo com essa versão, o falso Smérdis teria conclamado o exército a se rebelar contra Cambises, que estava em campanha $(D b ., 11)^{5}$, dizendo que era o legítimo filho de Ciro. Pouco a frente na mesma epígrafe, Dario reconhece que teve ajuda de poucos homens para tomar o trono do mago, porém, num primeiro momento não revela seus nomes $(D b ., 13)$. A identidade dos demais conspiradores só seria relevada no fim da inscrição, no parágrafo 68. Entretanto, o aquemênida não dá mais detalhes da participação destes homens na empreitada contra o palácio de Susa: apenas elenca seus nomes e, em seguida, afirma que quando se tornou rei declarou proteção às suas famílias, como uma espécie de gratidão. Logo, ele reivindica para si a responsabilidade pelo assassinato de Smérdis.

\footnotetext{
${ }^{4}$ Segundo Heródoto, Otanes desconfiou que o homem que ocupava o trono não era o verdadeiro filho de Ciro, porque esse Smérdis não saía da cidadela e nem convocava outros persas a sua presença (Hist., III.68), o que levantava suspeitas. Para comprovar a suspeita, ele adotou a seguinte estratégia: uma das filhas de Otanes tinha sido casada com Cambises e, após a morte do rei, passou a viver com Smérdis (ou com o homem que dizia ser Smérdis). Otanes sabia que o mago tivera as orelhas cortadas anteriormente como punição. Diante disso, ele pediu à filha que tateasse as orelhas do marido quando estivessem dormindo, para constatar se aquele era ou não o verdadeiro filho de Ciro. Se fosse o verdadeiro Smérdis, ele teria as orelhas. Caso fosse o mago, se passando pelo filho de Ciro, as orelhas teriam sido cortadas. A filha de Otanes seguiu as recomendações do pai e contribuiu para a descoberta da farsa (Hist., III.69).

${ }^{5}$ Tradução do persa para o francês por Pierre Lecoq, na obra Les inscriptions de la perse achéménide (1997).
} 
Além disso, Behistun nos diz que o mago foi morto em combate, e não em seus aposentos: houve uma batalha da qual o usurpador saiu derrotado, embora tenha conseguido fugir e se refugiar em uma fortaleza chamada Sikayahuvati. Somente após uma segunda derrota Smérdis foi definitivamente vencido $(D b ., 13)$.

Independentemente da versão, é possível que Heródoto tenha conhecido Behistun (ou pelo menos uma parte do documento) e o utilizado para compor a sua versão para a chegada de Dario ao trono da Pérsia. Nesse sentido, as duas versões parecem introduzir um elemento conhecido por alguns autores como o "falso-rei", um personagem que pode ser deliberadamente inventado para justificar um golpe de Estado: neste caso, a ilegitimidade de Smérdis poderia ter sido criada por Dario para justificar uma disputa pelo poder - da qual o aquemênida sairia vitorioso.

Para nós, o mais importante é que, cinco dias após a execução do mago e seus seguidores - e dentro do contexto da ascensão da figura política de Dario -, os conspiradores se reuniram e discutiram sobre as formas de governo.

Nessa reunião, o primeiro persa a falar foi Otanes, o homem que dera início à conspiração dos sete. Em sua fala, ele defendeu a adoção da democracia como forma de refrear os abusos cometidos pelos monarcas, como Cambises e Smérdis. Em seguida, Megabizo fez coro ao criticar o governo monárquico, mas também apontou problemas que seriam inerentes à democracia; sendo assim, propôs a instauração de um governo oligárquico, do qual ele e os demais conspiradores fariam parte. Por último, Dario rebateu as críticas dos outros persas e sugeriu que a monarquia deveria ser mantida por ser a melhor forma de governo. Após a votação dos outros quatro membros do grupo, essa opção prevaleceu e a Pérsia restaurou o governo aquemênida.

\section{Perspectivas}

Por conta das controvérsias, há mais de 100 anos os estudiosos buscam compreender essa passagem. Boa parte dos trabalhos sobre o debate persa se prende na discussão do fato histórico em si, ou seja, os autores demonstram interesse em investigar se é plausível que tal discussão tenha mesmo acontecido antes da coroação de Dario. Essa abordagem positivista enfrenta a barreira da falta de provas documentais para comparar com as Histórias - além de ser infrutífera, uma vez que a maior 
importância do fragmento é a descrição de Heródoto em si, que esboça um pensamento político sofisticado sobre as formas de governo.

Outra possível linha de pesquisa sobre o fragmento se debruça na construção textual da passagem, tentando verificar os elementos da gramática grega na construção da fala dos persas - sobretudo buscando referências na filosofia pré-socrática de autores como Protágoras. Essa corrente de estudos é limitada por não levar em consideração o contexto no qual Heródoto III.80-82 está inserido, trabalhando quase exclusivamente com os três capítulos em si.

Diante disso, nossa proposta é superar essas limitações impostas pela análise positivista e pela estrutura textual, e buscar o suporte da teoria política para melhor compreender o debate persa. O fato histórico em si é que Heródoto escreveu a passagem - seja ela verdadeira ou não, e isso causou um impacto para o pensamento político ocidental. E, analisando o contexto no qual o fragmento se encontra, percebemos a elaboração de um pensamento político acerca das formas de governo. O debate persa é uma passagem deveras emblemática por uma série de fatores, sobretudo porque o fragmento III.80-82 das Histórias constitui um dos mais antigos tratados de teoria política da história ocidental (ASHERI, 2006: 86; KAGAN apud EVANS, 1981: 79), que introduz a teoria da tripla classificação das constituições,

o governo de muitos, de poucos e de um só, ou seja, "democracia", "aristocracia" e "monarquia", embora naquela passagem não encontremos ainda todos os termos com que essas três modalidades de governo foram consignadas à tradição que permanece viva até nossos dias. (BOBBIO, 1985: 39).

Deste modo, Heródoto deixou um importante legado para o pensamento político ocidental, uma vez que se tornou o primeiro autor a teorizar a respeito das formas de governo $^{6}$. O texto herodotiano não elabora uma extensa teoria sobre a questão, porém, indica o debate acerca das constituições e propõe questionamentos importantes que envolvem a concentração e a distribuição de poder. Esse tipo de preocupação criaria um legado seguido por outros pensadores helênicos, como Platão e Aristóteles

\footnotetext{
${ }^{6}$ Muito provavelmente o debate sobre as formas de governo já era um assunto comum em cidades como Atenas no período de Heródoto, e até mesmo em épocas anteriores. Entretanto, até onde temos evidências ele foi o primeiro a teorizar esse tipo de discussão, colocando o debate entre monarquia, oligarquia e democracia na fala dos três persas.
} 
Bobbio resume bem a importância dos capítulos 80 a 82 do livro III das Histórias:

A passagem é verdadeiramente exemplar porque, como veremos, cada uma das três personagens defende uma das três formas de governo que poderíamos denominar de clássicas - não só porque foram transmitidas pelos autores clássicos mas também porque se tornaram categorias da reflexão política de todos os tempos (razão porque são clássicas e igualmente modernas). (BOBBIO, 1985: 40)

Entretanto, também é possível fazer outro tipo de leitura acerca da passagem que revela um pensamento político herodotiano ainda mais complexo sobre as formas de governo. Seria a possibilidade de interpretar o debate persa não a partir da tripla classificação, mas sim como uma hexa classificação das constituições. Isso é possível porque alguns argumentos utilizados nas falas de Otanes, Megabizo e Dario podem ser compreendidos como uma distinção entre as formas de governo boas e seus respectivos desvios constitucionais - resultando, portanto, em uma análise positiva e negativa para cada um dos modelos consagrados.

Por meio dessa proposta podemos afirmar que Otanes defende a democracia, porém, questiona não o governo monárquico, mas sim o tirânico (o governo de um só, mas baseado em uma administração arbitrária); Megabizo, por sua vez, critica a tirania, a oclocracia (governo de muitos, mas conduzido de forma amadora e egoísta pelos indivíduos) e propõe a adoção de uma constituição aristocrática; Dario, por último, reforça a crítica contra o governo da maioria (oclocracia), ataca o regime oligárquico e, em seguida, defende a adoção de uma monarquia.

Essa proposta sugere que Heródoto, portanto, não era apenas um pensador político, mas sim um autor que antecipou o debate feito tempos depois por Platão, Aristóteles e Políbio, dentre outros filósofos. O historiador, entretanto, não sistematizou sua explanação sobre as formas de governo, deixando muitos elementos indicados apenas implicitamente. 


\section{Estrutura da dissertação}

A realização deste trabalho demandou sua divisão em três capítulos, de modo a dar conta da discussão acerca do tema principal. Primeiramente, no capítulo Heródoto e a escrita das Histórias, realizamos uma revisão bibliográfica sobre o autor e sua obra, de modo a compreendermos quem foi o historiador e em que contexto seu livro foi escrito. Nessa etapa, discutimos, por exemplo, que Heródoto viveu em um contexto político no qual foi vítima das ações de um tirano, em Mileto - resultando em seu exílio. Essa informação é importante porque ajuda a compreender o motivo pelo qual as discussões acerca da tirania desempenham um papel de destaque na obra. Essa noção construída sobre o tirano será importante, nos dois capítulos seguintes, para pensarmos no modo como esse regime é comparado com a democracia ateniense.

Dedicamos uma parte deste primeiro capítulo da dissertação para analisar o modo como as Histórias foram produzidas, ou seja, sendo considerada uma obra de viagem cujo objetivo era conhecer o outro e, em seguida, retratá-lo para o público grego. Ao narrar as maravilhas vistas no oriente, Heródoto dedica um fragmento específico a mostrar a estranheza causada pelo debate entre Otanes, Megabizo e Dario (Hist., III.80).

Mostramos, ainda, como a obra herodotiana foi alvo de críticas e questionamentos quanto ao seu estatuto histórico, ou seja, em relação à sua legitimidade. Isso implica pensarmos o quanto as Histórias, e seus diversos problemas, foram questionados principalmente na primeira metade do século passado, e, posteriormente, como os especialistas reabilitaram a validade do documento.

Por fim, o primeiro capítulo é composto por uma revisão bibliográfica específica sobre o debate persa. Basicamente, os estudos sobre III.80-82 podem ser divididos em dois grupos majoritários, embora existam outras linhas de pesquisas menos expressivas. A primeira corrente reúne especialistas que investigam o fato histórico em si, buscando modos de comprovar ou refutar a verdade por trás da passagem. A outra linha apresenta uma marcante preocupação com a estrutura literária do fragmento, cujo principal objetivo é verificar possíveis influências gregas na fala dos três persas. Essa reflexão nos permitiu concluir que as duas correntes possuem limitações por não superar a preocupação com o positivismo histórico. E, nesse caso, a revisão bibliográfica é importante para indicarmos que nossa proposta é ir além dessas limitações, sugerindo a análise da passagem com o suporte da filosofia e da teoria política. 
A proposta do segundo capítulo, $O$ pensamento político nas Histórias, é investigar como o autor elabora seu pensamento político sobre as formas de governo, em trechos que estão além do debate persa, mas que ajudam a refletir sobre a discussão entre Otanes, Megabizo e Dario. Partindo da premissa de que o fragmento deve ser interpretado em um contexto mais amplo, investimos em uma análise separada das três constituições defendidas pelos nobres persas.

Essa análise, primeiramente, nos levou a concluir que tirania e monarquia são conceitos controversos nas Histórias, pois ambos são usados pelo autor quase como sinônimos em diversos pontos da obra. A análise do livro III, nos antecedentes do debate, sugere que naquele contexto específico o historiador retrata a monarquia/tirania persa por meio de um juízo valorativo negativo, pois atribui uma série de características contrárias à moral grega a partir da descrição dos governos de Cambises e Smérdis, como a violação de costumes ancestrais e o desrespeito religioso.

Essa ideia de monarquia/tirania é utilizada para a construção de uma identidade política ateniense, que por sua vez é baseada numa ideologização do conceito de democracia, comum aos pensadores do período. Esse governo democrático é retratado por Heródoto como um regime libertador que desperta a resistência cívica na pólis, em contraposição à constituição tirânica, que ataca os valores de liberdade e surge por conta da fraqueza cívica dos indivíduos. Essa concepção coloca democracia e monarquia em um antagonismo teórico nas Histórias.

O segundo capítulo demanda, ainda, uma análise sobre o governo de poucos, pois ele é um elemento fundamental no discurso de Megabizo. Constatamos que esse regime ocupa um papel inferior, se comparado às outras duas formas de governo. Mesmo assim, a oligarquia/aristocracia deve ser compreendida a partir de dois contextos distintos. O primeiro é a realidade ateniense, que mostra as influências das elites no jogo político, ora influenciando a queda do tirano Pisístrato, ora auxiliando em sua ascensão. O segundo caso está situado nos antecedentes do debate persa, nos quais identificamos ao menos uma sugestão de que Heródoto constrói uma rivalidade entre Otanes e Dario: que reflete, por sua vez, um choque entre as ideias dos grupos pródescentralização de poder e dos rivais pró-monarquia.

Compreendemos que esses conflitos entre grupos devem ser vistos como reflexos de uma situação oscilante entre caos e ordem nas Histórias, que culmina em 
problemas sociais e políticos e que, muitas vezes, cria as bases para a ascensão de governantes despóticos (como Smérdis, na Pérsia, e Pisístrato, em Atenas).

Uma importante conclusão do capítulo é que Heródoto indica um sofisticado pensamento político acerca das categorias de governo, porém, não sistematiza sua teoria política.

No terceiro capítulo, A teoria política sobre o debate persa, nos dedicamos a uma análise do fragmento III.80-82 com o suporte da filosofia política, com o intuito de dar nossa contribuição teórica acerca da passagem. Estudamos separadamente os discursos dos persas, projetando as análises do segundo capítulo em cada um dos casos.

O discurso de Otanes propõe uma crítica ao governante único, porém, utilizando argumentos contrários à tirania. A fala é fundamentada pelas críticas aos governos de Cambises e Smérdis - justamente os exemplos utilizados no nosso segundo capítulo para retratar o juízo valorativo negativo de Heródoto no contexto do debate persa. Além disso, Otanes propõe um governo popular em moldes semelhantes à constituição democrática ideologizada em Atenas, como a isonomia e a distribuição de cargo por sorteio.

A análise do discurso de Megabizo revela inicialmente uma crítica à tirania e ao governo popular. Porém, o persa utiliza argumentos distintos para questionar o regime popular, classificando-o implicitamente como uma oclocracia. Além disso, um ponto importante é que Heródoto, como narrador, afirma que Megabizo propõe a criação de uma oligarquia, enquanto a fala do persa indica características aristocráticas, como a competência dos melhores na composição do governo.

A arguição de Dario, por fim, revela o trecho mais teórico do debate persa. Nossa análise indica que o aquemênida é crítico da oclocracia e da oligarquia, constituições classificadas como desviadas por Aristóteles, e defende o restabelecimento da monarquia. No entanto, nossa interpretação também indica elementos de uma elaboração teórica mais complexa, que sugere a existência de um ciclo de constituições. Isso implica em uma transição natural entre uma forma de governo e outra: o argumento, nesse caso, é que a oclocracia e oligarquia são incapazes de produzir ordem e, por isso, fatalmente se degeneram de forma grave e apenas a ascensão de um líder monárquico é capaz de ordenar a sociedade. Novamente, é importante ressaltar que Heródoto não sistematiza a teoria, embora a fala de Dario nos dê indícios de seu 
pensamento político. Esse arranjo teórico só seria de fato sistematizado posteriormente, a partir da obra de autores como Políbio, por exemplo.

A partir das constatações oriundas desses três capítulos podemos concluir que existe sim um pensamento político nas Histórias, no sentido de indicar uma complexa teoria das formas de governo, não sistematizada pelo autor, que inclui a possibilidade de interpretarmos o fragmento III.80-82 como uma discussão não simplesmente entre as três constituições consagradas, mas também a partir da criação de um juízo valorativo das versões positiva e negativa acerca do governo de um, de poucos e da maioria. 


\section{Capítulo 1: Heródoto e a escrita das Histórias}

\subsection{O autor e a obra}

"Pai da História". Esse foi o epíteto atribuído posteriormente a Heródoto pelo filósofo e orador romano Cícero, título pelo qual genericamente é chamado até hoje. O motivo é que, segundo uma linha de entendimento bastante contestada, teria sido ele o "fundador" da prosa historiográfica. Embora caiba a Hecateu de Mileto ${ }^{7}$ o posto de primeiro historiador por ofício do Ocidente, foi Heródoto de Halicarnasso quem ganhou notoriedade por ter feito de suas Histórias ${ }^{8}$ uma espécie de modelo para a narrativa historiográfica helênica 9 .

É possível questionarmos o fato de Heródoto ser de fato o primeiro historiador grego, já que outros autores também ocuparam parte de sua vida a relatar fatos históricos, mesmo que de forma indireta, como Hesíodo e Homero, além de outros como o próprio Hecateu - que pode ter influenciado diretamente a obra herodotiana. Por outro lado, parte dos especialistas aponta Tucídides como o criador da historiografia (dentre os quais podemos citar HUTTON, 1911: 34), pois teria sido ele o primeiro a dar um novo tratamento aos fatos históricos, procurando distanciar-se de explicações atemporais para centrar-se apenas nos acontecimentos terrenos. Independentemente disso, há séculos a obra de Heródoto tem sido alvo de estudos a partir das mais diversas perspectivas.

Sua obra é composta por uma série de narrativas a respeito de histórias muito anteriores a seu nascimento. E, além disso, e o autor é considerado uma das principais

\footnotetext{
${ }^{7}$ Hecateu de Mileto foi o principal logógrafo da geração anterior a Heródoto e que provavelmente exerceu influência sobre a obra do historiador de Halicarnasso.

${ }^{8} \mathrm{O}$ texto de Heródoto é composto por três documentos distintos. O primeiro seria um conjunto de papiros datados do primeiro século depois de Cristo; o segundo seria um conjunto de manuscritos da Idade Média e da Renascença; o terceiro seria um conjunto de citações de autores gregos, greco-romanos e bizantinos. O terceiro grupo de documentos traz apenas variações de palavras e detalhes de menor importância historiográfica. O primeiro conjunto, os papiros, apresenta fragmentos do texto herodotiano. Nossa maior referência são os manuscritos, que por sua vez são divididos em algumas versões (CONDILO, 2010: 21 22). De qualquer forma, apesar das divergências dos documentos, a tradição historiográfica considera que todas as versões derivam de uma mesma edição antiga do texto - que nunca chegou até nós. Deste modo, trabalhamos com um documento não-autêntico, porém, provavelmente muito próximo do que deve ter sido essa edição original das Histórias.

${ }^{9}$ Segundo Boedeker, diversos outros textos em prosa anteriores a Heródoto, como a obra de Hecateu, tratam de assuntos historiográficos. Porém, boa tarde dessa documentação foi perdida, restando apenas pequenos trechos que normalmente são conhecidos por nós apenas por terem sido citados por outras fontes (BOEDEKER, 2011: 122).
} 
fontes sobre a história política grega e persa, sobretudo no que diz respeito ao período entre os séculos VII a.C. e V a.C..

Poucas informações a respeito de sua vida pessoal sobreviveram. Algumas, inclusive, são conhecidas por nós apenas a partir de fragmentos das Histórias nos quais o próprio Heródoto indica algum raro dado biográfico, como no famoso Proêmio da obra, no qual trata a si mesmo em terceira pessoa, indicando seu nome, para em seguida pontuar a cidade onde nasceu.

Deste modo, de acordo com as poucas informações que temos sobre o autor, Heródoto teria nascido em Halicarnasso, cidade de origem jônia localizada na costa da Ásia Menor, por volta de 480 a.C.. Portanto, ele foi contemporâneo das Guerras Médicas, os confrontos entre gregos e persas ${ }^{10}$ no século V a.C. que contribuíram para a construção de uma identidade ateniense em oposição ao invasor estrangeiro. $\mathrm{O}$ historiador provavelmente cresceu ouvindo as histórias sobre o conflito e sobre as notáveis vitórias dos exércitos helenos ante os invasores, sobretudo em Maratona e Salamina.

Heródoto era filho de Lyxes e Rhoio (ou Dryo). Sabemos que ele provavelmente foi membro de uma família de aristocratas em Halicarnasso, e que ainda na juventude se opôs ao governo de Lygdamis, da dinastia caria, que governava a cidade na época e que, além disso, mantinha uma aliança com os persas. Logo, a Cária era considerada uma província do império e, consequentemente, o historiador "nasceu súdito de Xerxes, então rei dos persas" (KURY, 1988: 7). Essa era uma situação comum para as póleis localizadas na costa da Ásia Menor no período, que sofriam a influência direta do governo de Susa - que em muitas oportunidades mantinha o governante local no poder, desde que ele se mantivesse fiel à Pérsia e se reportasse ao governo central - por exemplo, enviando tropas durante as campanhas militares e pagando os tributos.

Não conhecemos os detalhes dessa oposição política contra Lygdamis, mas sabemos que Heródoto participava da vida pública de Halicarnasso apoiado pelo tio, Paníasis, opositor da tirania que foi morto numa tentativa de depor o tirano.

A preocupação com as tiranias - comumente confundida com o governo monárquico - o levou a ocupar boa parte de sua vida intelectual à descrição de tiranos

\footnotetext{
${ }^{10}$ A primeira Guerra Médica data de 490 a.C., e terminou com a vitória ateniense na Batalha de Maratona. A segunda Guerra Médica contou com uma extraordinária força persa liderada por Xerxes, em 480 a.C., derrotada nas batalhas de Salamina e Plateia. Alguns autores argumentam que a participação decisiva de Atenas nas vitórias contribuiu para a construção do chamado Império Ateniense. Vamos explorar mais esse assunto no decorrer deste estudo.
} 
como Periandro, Pisístrato e outros, que viviam dentro do território helênico e fora dele. Esse tema foi debatido recentemente por Condilo, que concluiu que há muita ambiguidade no uso do conceito de "tirania" nas Histórias, pois nem sempre o autor dá a mesma conotação a ele. Ora, há um tom de neutralidade, ora de positividade, e em outras ocasiões essa forma de governo é representada negativamente, de modo que "é possível perceber uma oscilação de juízos valorativos sobre essa forma de governo ao longo da narrativa (CONDILO, 2010: 125). O modelo tradicional da tirania dos pisistrátidas em Atenas não é o único vigente na narrativa. As chamadas tiranias persas na Ásia Menor, e mesmo as tiranias da Sicília, por exemplo, apresentam poucas semelhanças com a tirania ateniense do período clássico. ${ }^{11}$

De qualquer forma, acreditamos que o livro III das Histórias, sobretudo no que diz respeito aos antecedentes do debate persa, indica um ponto de vista contrário às tiranias. Nesse trecho, o documento permite interpretarmos que o autor tinha um posicionamento político negativo em relação às gestões de Cambises e Smérdis frente à monarquia persa - e essa perspectiva é fundamental para o nosso estudo.

Seja como for, o problema com Lygdamis fez com que o historiador fosse exilado de sua pólis durante a maior parte da vida. Nesse período, percorreu diversas cidades gregas no continente e fora dele, além do Egito, ao longo do Mediterrâneo, talvez Mesopotâmia e até mesmo em localidades do Mar Negro que mantinham contato com cidades gregas (WATERS, 1996: 10). Não sabemos como Heródoto financiou suas viagens. Uma hipótese levantada por Romm (1998: 50) é que essas expedições podem ter sido feitas a bordo de embarcações mercantis; talvez o próprio autor tenha ganhado dinheiro com o comércio. Não há, contudo, evidências no documento que possam comprovar essa afirmação.

Heródoto viveu em Samos, provavelmente esteve em Atenas em 445 a.C., e, posteriormente, emigrou para Thurioi, entre 444 e 443 a.C.. A cidade fora fundada pelos próprios atenienses no Sul do que hoje conhecemos como península itálica (WATERS, 1996: 10), e lá o historiador conquistou a cidadania local. Por conta disso, alguns autores, como Aristóteles, o chamam de Heródoto de Thurioi, fazendo menção à sua pólis adotiva. Quanto à vida pessoal, não há evidências que comprovem a existência de

\footnotetext{
${ }^{11}$ O livro é o resultado de uma pesquisa de mestrado defendida no Departamento de História Social da USP, sob orientação do professor Dr. Norberto Luiz Guarinello. Para saber mais sobre o tema, ler CONDILO, Camila. Heródoto, as tiranias e o pensamento político nas Histórias. São Paulo: Annablume, 2010, $1^{\text {a }}$ edição.
} 
esposas ou filhos, e acredita-se que Heródoto tenha morrido aproximadamente em 425 a.C., em Pela, na Macedônia, ou na própria Thurioi.

Essa trajetória durante o exílio foi responsável por nos legar uma das obras mais importantes da historiografia helênica, cujo principal objetivo era explicar a origem dos conflitos entre helenos e não-helenos, curiosidade instigada pela herança das Guerras. Foi a primeira tentativa de se escrever uma história que relacionasse os povos em questão, bem como descrever e até certo ponto comparar suas diferentes religiões, hábitos culturais, divisões militares, dentre outros aspectos. Heródoto, com isso, nos deu importantes indicativos para compreendermos os processos de integração entre as diversas regiões do chamado mundo grego entre si, e com os povos estrangeiros.

$\mathrm{Na}$ obra, o autor se preocupou inclusive em descrever e explicar, sob sua perspectiva, os modelos e instituições políticas dos chamados povos bárbaros. Isso inclui a polêmica narrativa a respeito da defesa da democracia, presente no fragmento III.80-82 - um dos alvos deste estudo. 


\subsection{Narrativa de viagem}

Conforme dito anteriormente, as Histórias não podem ser consideradas uma obra escrita "no gabinete". Sua execução só pode ser realizada por conta das diversas expedições que Heródoto empreendeu em seu tempo. Sendo assim, podemos retomar alguns argumentos usados no precioso estudo de Hartog sobre os citas - que nos ajudam a compreender o método de trabalho utilizado pelo historiador e sua forma de construir os relatos.

A primeira observação relevante é que Hartog classifica a obra de Heródoto como uma narrativa de viagem, não apenas porque o historiador se deslocou até lugares distantes do mundo grego para buscar informações sobre os chamados bárbaros, mas sim porque esse método implica na possibilidade de produzir um texto que leva ao público relatos sobre as maravilhas/curiosidades a respeito dos povos descritos. Essa prática, segundo Redfield, teria nascido com Odisseu, e representa, no limite, ir até o desconhecido para observar (2002: 25) ${ }^{12}$. Heródoto, portanto, teve a possibilidade de conhecer um grande conjunto de coisas que poderiam ser lidas nas ágoras das póleis gregas. Essas maravilhas, ou thôma, são importantes figuras de retórica de alteridade: é uma forma possível de traduzir a diferença entre o que há no mundo grego e o que há no mundo bárbaro (HARTOG, 1999: 245-246). Para Gruen (2011: 1), a alteridade serve, sobretudo, para a construção de uma espécie de declaração de superioridade, tratando o diferente como inferior.

O debate persa, alvo da nossa investigação, pode ser considerado um desses elementos surpreendentes e curiosos que foram levados ao público grego por Heródoto. De certa forma, sem problematizar a fonte e o documento ${ }^{13}$, o fragmento mostrou aos helenos que os nobres da Pérsia também eram capazes de debater aspectos da filosofia política como as vantagens da constituição democrática em detrimento de uma suposta arbitrariedade da monarquia (posição marcada pelo discurso de Otanes), algo bastante externo à realidade do império fundado por Ciro. Ao narrar esse thôma na obra, o

\footnotetext{
${ }^{12}$ Segundo Redfield, Heródoto indica que existem três motivos para viajar. O primeiro seria o comércio; o segundo, a guerra; por fim, viaja-se para observar (2001: 24). O autor se baseia no fragmento III.139 para defender essa ideia. A passagem se refere à conquista de Samos por Dario, e menciona que, quando Cambises invadiu o Egito, muitos helenos foram para lá com finalidades diversas: alguns foram com o exército persa, enquanto outros foram negociar. Por último, o documento cita que outros gregos viajaram simplesmente para conhecer o território conquistado.

${ }^{13}$ Devemos considerar, como faremos nos capítulos seguintes desta dissertação, que, independentemente de ser verdadeira ou não, essa passagem das Histórias é fundamental para consolidar o debate sobre as formas de governo no mundo Antigo.
} 
próprio autor se preocupou em esclarecer que os discursos pronunciados no diálogo entre Otanes, Megabizo e Dario poderiam ser "considerados incríveis por alguns helenos" (HERÓDOTO, Hist., III.80), tamanho o choque que o trecho poderia causar nos leitores gregos. Aplicando a teoria de Hartog, podemos interpretar que Heródoto tentou, com essa frase, preparar seu público-leitor para o relato da "curiosidade" que se seguiria - e que seria surpreendente.

Seguindo para mais um ponto da obra de Hartog, temos que o historiador de Halicarnasso trabalha com um esquema de comparações e criação de analogias como forma de "traduzir" costumes e tradições estrangeiras para seu público helênico. Heródoto, explica o autor, descreve determinada prática religiosa persa, por exemplo, e depois encontra um paralelo grego para melhor explicar o fato descrito - muito embora, às vezes, os objetos comparados não sejam exatamente equivalentes. Entretanto, seria uma ferramenta metodológica utilizada pelo autor para levar a seu público uma compreensão facilitada das informações que colheu em suas viagens, porque, deste modo,

(...) Heródoto estima que um pode ajudar a fazer com que se veja melhor o que é o outro, valendo a pena, ainda que só por um instante, aproximá-los: as tochas que passam de mão em mão (nas provas gregas das lampadoforias) são como as notícias que se divulgam de mensageiro em mensageiro até o palácio real de Susa. (...) A analogia desempenha um papel importante nas origens da ciência grega, em que funciona tanto como método de invenção, quanto como sistema de explicação. É, pois, interessante ver uma narrativa como as Histórias recorrer a esse verdadeiro modo de conhecimento que é o conhecimento 'por comparação', adaptando-o a seu próprio uso. (HARTOG, 1999: 242-244).

Portanto, a narrativa de viagem pressupõe que o autor vai, em muitos momentos, apresentar o thôma a seus leitores fazendo uma analogia entre eles e elementos comuns à cultura grega, quase como num exercício de "tradução" - que evidentemente também causa muitos problemas pelo fato de algumas comparações não serem exatamente apropriadas.

Ainda pensando na perspectiva das Histórias como uma obra de viagem, Pascal Payen publicou um interessante estudo intitulado Hérodote et Lévi-Strauss: questions 
d'ethnographie ${ }^{14}$, no qual traça um paralelo entre o texto de Heródoto e a antropologia. Segundo o autor, há uma semelhança nos métodos empregados pelo historiador grego e pelo antropólogo francês Claude Lévi-Strauss, pois ambos escreveram grandes obras com base em relatos obtidos a partir de expedições realizadas pelos autores.

Payen argumenta que a tradição Ocidental situa o início desse tipo de obra em Hecateu e Heródoto (PAYEN, 2013: 179), que, a exemplo de Lévi-Strauss, em Tristes Trópicos, viajaram a terras longínquas para conhecer não apenas a história, mas também a cultura e os costumes dos povos estrangeiros, praticamente vivenciando suas rotinas e interagindo com os moradores e autoridades locais ${ }^{15}$. Do ponto de vista metodológico, é como uma imersão na cultura do outro para estudá-la a partir de seu próprio ponto de vista e com base em seus próprios termos, construindo uma pesquisa classificada pelas ciências sociais como sendo qualitativa.

A partir dessa constatação inicial, Payen traça alguns pontos de analogia entre as Histórias e Tristes Trópicos (2013: 180-181), sendo que um dos apontamentos mais relevantes é o fato de que ambos os autores demonstraram uma grande preocupação no momento de retratar a visão "do outro" - e fizeram isso se valendo de entrevistas e da observação dos costumes das sociedades analisadas. São trabalhos que unem as práticas da história com a etnografia, embora Heródoto não deixe esse objetivo explícito (PAYEN, 2013: 182). Isso implica pensarmos que Heródoto não apenas retratou os persas a partir de uma suposta perspectiva grega (a visão helênica do outro), mas também buscou mostrar os Orientais a partir de seus próprios termos e experiências políticas, como a suposta crítica da democracia feita por Otanes (HERÓDOTO, Hist., III.80).

Payen cita ainda outra obra de Lévi-Strauss, Ethnologie et histoire, na qual o antropólogo francês diferencia as duas ciências: segundo o autor, a história toma como objeto expressões conscientes da vida das sociedades, enquanto a etnologia analisa as estruturas inconscientes que subjazem às instituições ou aos costumes (2013: 182). Logo, ouvir o estrangeiro é não apenas relatar o que se vê, mas também o que se ouve e aprende com ele, podendo buscar um modo de narrar os fatos a partir de outro ponto de vista, ou seja, a partir da perspectiva do próprio descrito.

\footnotetext{
${ }^{14}$ Publicado no livro Hérodote: formes de pensée, figure du récit, páginas 179 a 196, da Presses Universitaires de Rennes, de 2013.

${ }^{15}$ Autoridades como os sacerdotes dos templos egípcios, que ajudaram Heródoto a construir sua versão para as histórias locais dessas sociedades.
} 
Contudo, é preciso problematizar essa perspectiva. Heródoto pode, como realmente fez, ter dado a oportunidade para o "outro" contar a sua versão da história. Porém, a seleção das fontes de informação também é um filtro importante para pensarmos nessa narrativa de viagem: o historiador escolheu quem seria ouvido e qual versão seria contada ao público grego - e selecionou também o que seria descrito e o que seria descartado na obra.

Portanto, conclui Payen, qualquer narrativa deste tipo, que se vale de viagens de exploração para a descrição dos fatos, está sujeita ao olhar, aos ouvidos e às escolhas de quem faz as observações e a interpretação dos relatos. É que, após o exercício de observação e apuração dos dados in loco, o historiador precisa deglutir aquelas informações e nesse momento pode causar distorções em relação à realidade. A prosa historiográfica e a etnográfica, completa o autor, são indissociáveis do sujeito que olha, escuta e escreve as várias versões (2013: 187).

Ainda que as narrativas herodotianas estejam repletas de contradições e questionamentos, a obra de fato é singular. Por meio dela, Heródoto se consagrou como uma das principais fontes para o estudo da Grécia Antiga, podendo ser considerado não apenas um historiador, mas também um geógrafo, etnógrafo e pensador político. Essa diversidade de abordagens, somada às inúmeras digressões do documento, por vezes é criticada por dificultar uma melhor compreensão da totalidade da obra. De qualquer forma, as Histórias tornam Heródoto um autor importante para o estudo de um longo período histórico na Antiguidade. Reside nisso, aliás, uma das maiores complexidades para se ler e interpretar o texto, pois envolve a narrativa de assuntos presenciados pelo historiador, como festivais no Egito dos quais ele foi testemunha ocular, eventos de períodos anteriores ao seu nascimento, para os quais depende inteiramente de depoimentos de terceiros, e histórias muito antigas, que remontam à total ausência de testemunhas vivas e, portanto, inteiramente dependentes da tradição oral.

Oswyn Murray, em seu estudo sobre o surgimento e o desenvolvimento da escrita histórica na Grécia, defende que

O resultado (das Histórias) é mais do que um relatório das causas e eventos de um mero conflito. Prefiro afirmar que é um quadro total do mundo conhecido, no qual a geografia, os costumes, as crenças e os movimentos de cada povo são no mínimo tão importantes quanto sua relação frequentemente tensa na guerra. É nisso que a obra de Heródoto nos aprofunda, sendo uma grande obra de arte e 
ao mesmo tempo uma convincente história de um conflito, não apenas entre dois povos, mas sim entre dois tipos de sociedade, o igualitarismo da cidadeestado mediterrânea e o despotismo Oriental do Oriente Médio (MURRAY, 1988: 218-219). ${ }^{16}$

Momigliano ressalta outra característica marcante no trabalho de Heródoto: ter utilizado três elementos de investigação distintos, "etnografia, investigação sobre a constituição e história militar", deixando evidente, em sua opinião, que o historiador estava "profundamente conectado com a investigação histórica, com a consequência de que uma série de feitos se tratava implícita e explicitamente como a explicação de outra série" (1984: 12). Em outras palavras, Momigliano argumenta que Heródoto não apenas elencou fatos, mas sim os interpretou e os inseriu num contexto de longa duração, evidentemente com as limitações de uma época na qual a história não era uma disciplina como hoje.

\footnotetext{
${ }^{16}$ Ao usar a oposição entre o igualitarismo da cidade-estado e o despotismo oriental, Murray parece adotar uma leitura ocidental da obra de Heródoto, ou seja, aquela que defende que a monarquia ocidental era um regime político similar (quando não um sinônimo) de tirania. Ao mesmo tempo, essa visão toma a democracia ateniense do século $\mathrm{V}$ a.C. como o modelo político grego, quando na verdade pode ser interpretado como uma exceção, por ter surgido apenas no fim do período clássico.
} 


\subsection{O estatuto histórico das Histórias}

Antes de avançarmos na nossa discussão sobre o debate persa, é preciso fazer algumas ponderações acerca das críticas recebidas por Heródoto no que diz respeito à legitimidade do seu trabalho. Desde a Antiguidade, a obra do historiador está envolta em polêmicas - a menção à democracia, no discurso de Otanes, é apenas uma delas. Diversas outras passagens também resultam em controvérsias, que por vezes remetem à questão do estatuto das Histórias como documento histórico válido.

Podemos dizer que boa parte dos questionamentos sempre esteve mais ligada às supostas incorreções de informação relatadas pelo historiador. Porém, para alguns autores contemporâneos, o problema está relacionado a outros fatores, como a mescla de elementos míticos na narração (o que causaria um problema quanto à objetividade e à racionalidade do texto) e o uso de instrumentos metodológicos como a construção de tipos ideais das personalidades descritas nas Histórias, como os arquétipos dos líderes orientais.

Mesmo na Antiguidade a obra de Heródoto recebia críticas, fazendo com que o autor tivesse a reputação questionada por alguns pensadores gregos e romanos. Um dos primeiros a levantar suspeitas quanto à obra herodotiana foi o ateniense Tucídides, autor do relato da guerra entre atenienses e espartanos e que, ao lado do historiador de Halicarnasso, é considerado um dos primeiros grandes autores da prosa historiográfica (GRETHLEIN, 2011: 148). Ao discorrer sobre os méritos de seu próprio trabalho, o historiador de Atenas afirma que os logógrafos compunham suas obras com o objetivo de agradar aos ouvidos do público, e não para contar a verdade (TUCÍDIDES, Pelop., I.21) - de modo que o seu trabalho teria mais validade. Para alguns estudiosos, como Kury $^{17}$, essa seria uma alusão indireta a Heródoto, a quem Tucídides vira pessoalmente, ainda na adolescência, durante as recitações das Histórias na ágora. A hipótese é que o sucesso da leitura pública dependia da atenção e do interesse dos ouvintes e, para atingir essa meta, Heródoto buscava formas de escrever para agradar essa audiência, não assumindo necessariamente um compromisso com a verdade dos fatos. É um tipo de crítica positivista.

Outro pensador antigo que não poupou críticas ao autor de Halicarnasso foi Plutarco. Além de questionar incorreções nas informações descritas nas Histórias,

\footnotetext{
${ }^{17}$ Conforme consta em uma nota de rodapé da tradução de Mario da Gama Kury a respeito da passagem I.21 da História da Guerra do Peloponeso.
} 
Plutarco questiona o resultado do método etnográfico do historiador, classificando-o como "filobárbaro" (857, A, 12) por ter dado voz aos estrangeiros e ter demonstrado, em sua opinião, uma preferência pelos estrangeiros e seus costumes. Plutarco escreve inúmeros outros comentários depreciativos a Heródoto em sua obra Da Malícia de Heródoto, quase todas no sentido de alegar que ele tinha uma predileção aos estrangeiros em relação aos helenos, como demonstra a passagem a seguir:

(...) E isso não é impressionante; mas o é quando remonta à estirpe de Héracles a Perseu e afirma que Perseu nasceu de um assírio, segundo o relato dos persas. E diz que "os comandantes dórios pareciam ser egípcios autóctones, para quem lista os antepassados de Dânae e Acrísio”. Abandona por completo Épafo, Io, Jasão e Argo, ambicionando somente declarar outros Héracles egípcio e fenício, mas também isso que ele afirma ser a terceira geração, para bani-la da Grécia e conduzi-la aos bárbaros. (PLUTARCO, 857, E, 14) ${ }^{18}$

As críticas a Heródoto não cessaram com Tucídides e Plutarco. Autores contemporâneos também se debruçaram sobre o texto herodotiano para indicar suas contradições. Nos últimos 100 anos, por exemplo, muitos pesquisadores dedicaram seu trabalho a analisar criteriosamente a narrativa de Heródoto, buscando novas formas de interpretar sua obra. O resultado foi uma série de possibilidades distintas para se compreender as Histórias, nem todas elas dando crédito ao historiador de Halicarnasso. Isso ocorre porque parte desses trabalhos apontou problemas considerados suficientemente graves, na visão dos pesquisadores, para colocar em dúvida a legitimidade do documento.

Uma das principais correntes de análise sobre a obra herodotiana estava centrada na análise da estrutura narrativa do documento, de modo a compreender os elementos textuais que compunham os diversos conjuntos narrativos. A outra parte da produção, por sua vez, tinha uma marcante preocupação com o estatuto histórico do autor e de sua obra (CONDILO, 2010: 26). Isso implica pensarmos que estava em discussão a validade do texto de Heródoto no que diz respeito à sua confiabilidade.

Essa segunda linha de pensamento sobre as Histórias caminhava por análises complexas e, por conta disso, acabou se dividindo em duas correntes antagônicas. De um lado havia os autores que encontravam na obra problemas sérios para de fato colocar

\footnotetext{
${ }^{18}$ Documento com tradução para o português de Maria Aparecida de Oliveira Silva, doutora em História Social pela USP e especialista na obra de Plutarco.
} 
em dúvida a legitimidade do documento. De outro, pesquisadores que buscavam argumentos para considerar Heródoto um autor essencial para a compreensão do mundo helênico e do chamado mundo bárbaro, mesmo que diversas ponderações fossem necessárias durante esse processo.

Um dos principais estudiosos da obra herodotiana no início do século passado foi Maurice Hutton. Segundo ele, muitos autores preferem chamar Heródoto de "Pai da Mentira" - e não "Pai da História" (HUTTON, 1911: 33) por conta da inconsistência de informações presentes no documento, o que colocaria em dúvida a legitimidade de determinadas narrações contidas no texto.

Contudo, o próprio autor argumenta que

(...) ele não era apenas historiador, mas também um poeta. Ele olhou as pessoas e os eventos ao redor; ele viu homens e fatos; ele generalizou vida e história. (...) Tucídides é chamado de historiador científico, e neste sentido Heródoto não foi um historiador científico. Ele gostava tanto do caráter humano enquanto indivíduo (HUTTON, 1911: 33-34).

A afirmação de Hutton leva em consideração um conceito de história que nós, contemporâneos, adotamos, mas que era desconhecido dos antigos. Nesse sentido, precisamos pensar que o autor tinha, também, uma preocupação em tornar sua obra de interesse popular, o que o fazia recorrer a um estilo narrativo mais facilmente aceito pelas pessoas. E, além disso, é preciso pensar que o historiador escreveu em um momento de passagem entre o pensamento mitológico e o pensamento voltado à compreensão do funcionamento dos grupos e das ações humanas, normalmente usando como fonte de informações a tradição oral - que por sua vez era repleta de estórias mitificadas que eram transmitidas de geração em geração. Segundo Ranke,

Tudo estava apoiado em tradições orais; e abordava um acontecimento que, ocorrido há várias décadas, não foi presenciado diretamente pelo historiador e para o qual não era possível encontrar testemunhas fidedignas a respeito do tema de sua obra (RANKE, 2011:254) 
Ainda sobre o mito, Marincola explica que, na Antiguidade, os historiadores não mantinham uma distância do seu objeto de estudos, muitas vezes assumindo os valores do próprio objeto (2010: 5). Contudo, o autor argumenta que talvez isso fosse algo inevitável, não apenas porque a narrativa historiográfica era um estilo ainda em construção, mas também porque o passado tinha uma presença quase onipresente nas póleis, como as epígrafes e representações imagéticas contidas nos frisos de templos e em outros monumentos presentes em praticamente todo o mundo grego - o que também afetava a tradição oral da qual Heródoto se valeu para produzir seu texto.

Se tomarmos como exemplo a stoa poikile, em Atenas (também conhecida como Pórtico Pintado), erigida no século V a.C., veremos que ela possui representações do general Milcíades e da Batalha de Maratona (fato bastante retratado pela historiografia helênica, inclusive por Heródoto), além do mítico combate contra as amazonas e o rapto de Cassandra por Ajax (GEHRKE, 2011: 52). Isso quer dizer que, para os atenienses, os dois fatos ocupam um lugar de destaque na memória coletiva daquela sociedade. Gehrke ressalta que, com este exemplo, observamos que o conflito contra os persas passou a ocupar parte do mito ateniense (2011: 53), tamanha sua importância para a formação de uma espécie de identidade helênica perante uma identidade tida como bárbara.

História, tal como concebido pelos antigos, foi, portanto, algo derivado essencialmente do mito. Somado a isso, tínhamos o que rudimentarmente era conhecido sobre a história "real" e que raramente não tinha sido vestida com a roupa do mito e "mitificado". Como a história que se acreditava, as histórias e sagas foram, no entanto, de grande importância e não raro decisivas para a vida real e para o comportamento político. Gostaria de sugerir o nome de "história intencional" e empregá-la no que se segue. O conceito de intenção, tal como é entendido aqui, é emprestado da sociologia étnica, sobretudo o conceito de Wilhelm Muhlmann, que enfatizou o aspecto de auto-classificação e da consciência, da subjetividade e até mesmo a intencionalidade (e da autoestilização conectado com ele), como facções essenciais na determinação das tribos ou grandes grupos étnicos semelhantes. (GEHRKE, 2011: 50-51).

Além da presença do mítico na narrativa, a obra de Heródoto também é questionada por conta de diversos problemas quanto às informações relatadas no documento. Asheri (2006: 31), por exemplo, afirma que o historiador é preciso em 
diversos aspectos, como na descrição das satrápias estabelecidas por Dario e o respectivo tributo que cada uma deveria pagar ao governo central, porém, impreciso em outros, sobretudo no que diz respeito à descrição da personalidade dos líderes orientais. Segundo o autor, o historiador constrói modelos de personificação ideal dessas figuras, usando arquétipos como o rei-pai, o tirano-cruel, o sábio-administrador, dentre outros. Esse método seria uma herança da tradição literária e da moral gregas, e não o resultado da interpretação de documentos autênticos.

O resultado é que muitos desses personagens acabam sendo retratados por meio de estereótipos, que se por um lado facilitam a compreensão do leitor, por outro colocaram em dúvida a real competência de Heródoto na descrição do perfil desses grandes líderes políticos. No próximo capítulo, voltaremos a discutir a respeito desses tipos ideais mencionados por Asheri, pois eles são importantes para verificarmos como o historiador constrói a visão das monarquias/tiranias nos antecedentes do debate persa.

Ainda quanto às supostas incorreções, Hutton foi além da crítica dos tipos ideais e colocou em dúvida inclusive a suposta viagem de Heródoto à Babilônia. Segundo o autor, o historiador teria confundido estátuas de deuses, templos e até mesmo a localização das muralhas da cidade (HUTTON, 1911: 36). Para ele, esses erros só foram causados porque Heródoto provavelmente nunca esteve de fato na Babilônia - embora o historiador grego tenha afirmado que sim.

A complexidade de temas tratados, as longas digressões e a ausência de fontes para comprovar determinadas narrativas também são apontadas como problemáticas para a compreensão da obra. O historiador afirma nas Histórias que iria contar os relatos conforme ouviu (HERÓDOTO, Hist., II, 99). Porém, a questão é saber quem foi ouvido para que ele pudesse construir a sua versão dessa história.

Em algumas oportunidades, no entanto, o historiador nos informa genericamente quem lhe passou as informações, usando termos como "os sacerdotes do templo". Mas na maior parte dos casos ele não cita a fonte. Esse não é um problema que afeta apenas Heródoto. Segundo Finley,

não constituía um hábito evidente dos historiadores antigos parafrasear ou, ainda raramente, citar um documento. Tucídides omitiu de maneira notória qualquer referência a documentos na definição de seu método (I.22), fazendo uso declarado deles em apenas um pequeno número de vezes, muito embora demonstrasse, 
num contexto que era essencialmente irrelevante para sua história, o que se podia fazer para se obter testemunhos através de inferência lógica de duas breves inscrições (VI.55). Parte da indiferença universal dos historiadores gregos e romanos pelos documentos jaz na escassez destes e no estado rudimentar dos arquivos. (FINLEY, 1994: 22)

A ausência da citação da fonte ou documento atinge a narrativa do debate persa. Em nenhum momento dessa passagem o autor nos dá indícios de quem foi a fonte de informação. Sabemos, no entanto, que Heródoto não foi testemunha ocular do diálogo entre Dario, Otanes e Megabizo - ele ainda não havia nascido. O historiador tampouco teve acesso a possíveis fontes epigráficas ou arqueológicas sobre o fato - já que, se existem, ainda não foram reveladas.

Segundo Asheri (2006: 30), a história factual e política persa é quase totalmente escrita a partir de fontes gregas, já que os orientais contribuíram pouco nesse sentido. Aquela civilização não possuía uma tradição historiográfica preocupada em produzir grandes documentos sobre a própria história. Os persas, de forma geral, faziam registros históricos mais cotidianos em inscrições e tabletes, por exemplo, normalmente usados para narrar fatos referentes às práticas diárias da administração pública ou registros econômicos, e não para guardar a memória de campanhas militares. Esse tipo de registro, quando feito, tinha um caráter muito mais de discurso político, como ocorre com a Inscrição de Behistun.

Outro problema quanto às Histórias diz respeito à mistura de temas dentro da estrutura narrativa do texto. Hartog (1999: p. 261-262) destaca como exemplo o livro IV, no qual os capítulos 2 a 82 descrevem detalhadamente a Cítia e suas leis, enquanto o capítulo 1 e, posteriormente, dos capítulos 83 a 144, descrevem a expedição de Dario. Isso mostra, segundo Romm (1988: 32), que o historiador não segue necessariamente uma ordem cronológica direta - e muitas vezes nem mesmo segue uma sequência lógica dos assuntos abordados. No meio de uma narrativa, o historiador faz longos flashbacks (ou flash forwards), para depois voltar à narrativa principal. Isso ocorre ao longo de toda a obra, como, por exemplo, na narrativa da Revolta Jônia (Hist., V.28-126), interrompida sucessivas vezes para explicações paralelas sobre a história de Esparta, a 
ida do espartano Dorieu à Líbia e à Sicília e até mesmo sobre a origem do alfabeto grego com base no fenício, dentre outros assuntos.

Há casos, porém, em que o historiador se compromete a retomar determinados assuntos posteriormente, mas não o faz após uma longa digressão (EVANS, 1991: 89). Isso pode sugerir que a obra, como chegou até nós, não estava completamente finalizada. Evans lembra que o documento pode ter sido levado a público, nas ágoras, sem que tenha sido de fato concluída. Uma suposição é que partes da obra podem ter sido apresentadas ao público separadamente, antes que o conjunto estivesse devidamente finalizado (1991: 90).

Independentemente das críticas quanto ao estatuto histórico, a obra de Heródoto se tornou um clássico consagrado. É, sem dúvidas, uma das principais fontes para a história política e social das póleis gregas, bem como sobre as Guerras Médicas. A obra do historiador sobreviveu às críticas da Antiguidade e foi reabilitada no século XVI, em parte por conta da exploração do Novo Mundo (CONDILO, 2010: 25). O motivo é que os contatos entre os colonizadores europeus e as populações latino-americanas, por exemplo, se assemelhavam com os primeiros contatos entre gregos e estrangeiros, como persas e egípcios, narrados por Heródoto - ambos são relatos do contato de europeus com sociedades até então pouco desconhecidas.

Posteriormente, a reforma religiosa serviria para dar um novo viés à importância das Histórias, desta vez como fundamentação para a história bíblica (MOMIGLIANO, 1983: 180-185). O especial interesse de Heródoto pelo Oriente Antigo servia como suporte para a leitura do Velho Testamento e, com isso, para a ampliação do conhecimento sobre importantes figuras históricas que também aparecem nos textos bíblicos, como o próprio Dario - um dos protagonistas do debate persa.

O estabelecimento da história como disciplina, no século XIX, contribuiu, novamente, para que o interesse pela obra herodotiana fosse reavivado pelas novas gerações de pesquisadores, mas desta vez a partir da busca positivista pela verdade histórica da narrativa. Os trabalhos publicados a partir deste período são marcados pela análise da narrativa factual, no intuito de interpretar os fatos da forma como eles supostamente aconteceram na realidade. Por conta da ausência de fontes, da obsessão de alguns pesquisadores com o estatuto histórico de Heródoto e do positivismo histórico, o debate persa foi bastante rejeitado no século passado. A passagem foi considerada por muitos pesquisadores como sendo completamente fictícia. 
Logo, as Histórias ganharam muito destaque na produção acadêmica deste período, entretanto, é preciso ressaltar que durante todo esse tempo houve críticas à competência de Heródoto como historiador, dividindo opiniões entre os que defendiam a legitimidade do seu trabalho e aqueles que o questionavam por conta de eventuais imprecisões históricas, por causa das extensas digressões do texto (que dificultavam o entendimento cronológico da narração) e da presença de elementos míticos na narrativa - como Hutton o fez.

A partir da segunda metade do século XX e a virada epistemológica que passava a afetar a ciência histórica, buscaram-se novas formas de interpretar a obra herodotiana. Uma das principais contribuições veio da antropologia, que propunha novas interpretações para as Histórias, mostrando as tentativas de Heródoto em retratar os fatos a partir da visão do "outro".

Até agora falamos brevemente das abordagens críticas, como a de Hutton. Porém, outros autores saíram em defesa de Heródoto, como Hering (2004: 217), para quem o autor não teria construído um "mosaico desconexo" e à sombra da objetividade narrativa de Tucídides, que mais uma vez questionaria a legitimidade do autor, mas sim uma obra com sua lógica própria. Essa lógica seria, para muitos, a compreensão do documento não a partir de fragmentos isolados - que certamente tornariam a sua compreensão prejudicada - mas sim a partir da junção das unidades, formando um amplo conjunto narrativo.

Esse, na realidade, é um entendimento que se destacava em parte das pesquisas sobre Heródoto há algumas décadas. Diversos autores procuraram, a sua maneira, unir esses fragmentos criando assim uma espécie de divisão dos lógoi a partir de critérios específicos, como, por exemplo, a divisão proposta por Immerwahr (1986: 79), que leva em consideração os grandes temas ligados à ascensão e à queda dos grandes líderes orientais: Creso, Ciro, dentre outros. Esse agrupamento resultou em uma divisão de 11 lógoi principais. Abaixo, temos uma tabela que mostra essa divisão proposta pelo autor. Ela serve simplesmente para ilustrar a tentativa desses pesquisadores em encontrar um modo de colocar cada narrativa dentro de um contexto mais amplo e, assim, dar um novo sentido às Histórias. 


\section{Quadro 1: Lógoi das Histórias}

\section{Prefácio}

\section{O logos de Cresos}

\section{Origens da Pérsia, de Ciro e a ascensão de Ciro}

\section{Campanhas de Ciro}

\section{Campanhas de Cambises}

\section{A Guerra de Esparta contra Polícrates de Samos}

\section{Revolta dos Magos e a ascensão de Dario}

\section{O poder de Dario}

\section{As cinco anedotas}

\section{As campanhas de Dario}

\section{A campanha grega de Xerxes e Mardônio}

Fonte: IMMERWAHR, HR. Form and thought in Herodotus. Atlanta: Scholars Press, 1986, p. 79.

É preciso ressaltar que esse tipo de divisão é artificial, pois foi feita posteriormente, e não elaborada pelo próprio Heródoto. Contudo, ela ajudou os pesquisadores do período a colocar cada conjunto narrativo dentro de um contexto de longa duração. A partir deste entendimento, verificamos que o texto começa narrando o início dos conflitos, no Prefácio, segue para a história de Creso, para a ascensão de Ciro e Cambises. Narra, na sequência, os eventos envolvendo Esparta e Samos. Volta à Pérsia, para o início da narrativa de Dario. Por último, mostra a derrota de Xerxes na Grécia, após a campanha de 480 a.C..

Cabe ressaltar que qualquer tentativa de construir um esquema de lógoi por parte dos pesquisadores pode funcionar bem para fins didáticos, de modo a facilitar a compreensão da obra como um todo, contudo, apresenta um grau de subjetividade devido às escolhas feitas para a divisão.

Além dessa divisão do documento em lógoi (seja pela divisão de Immerwahr ou qualquer outra), convencionou-se apresentar a obra como um conjunto de nove livros, cada um deles batizado com o nome de uma musa. Essa divisão também é tardia, provavelmente adotada no período helenístico e remonta ao modo como o texto era lido por seu público da época (HARTOG, 1999: 32-33), e utilizada até hoje também por representar uma espécie de agrupamento dos diversos conjuntos narrativos em contextos bem mais amplos. 
Segundo Hartog (1999: p. 261-262), a partir dessa divisão das Histórias em nove livros temos a seguinte composição da obra: os quatro primeiros tomos seriam principalmente uma descrição dos diferentes nómoi de povos não-gregos (persas, egípcios, lídios, babilônios, etc.); os cinco livros seguintes contariam a história das Guerras Médicas ${ }^{19}$.

A partir destas novas perspectivas, de analisar a obra a partir de um contexto mais amplo e com uma lógica própria, diversos autores passaram a considerar Heródoto como um legítimo historiador, compreendendo que seu documento só faz sentido a partir de uma leitura conjunta dos diversos lógoi. Caso contrário, a narrativa ficaria desconexa. Dentre os autores mais influentes que adotaram essa forma de compreender o documento podemos citar Flory (1987) e Darbo-Peschanski (1998), além do próprio Hartog (1999).

Nesta perspectiva, é fundamental pensarmos em Heródoto como um autor dentro de um contexto, de modo que "documentos sejam recolocados na época de sua produção, agrupados, comparados e criticados" (GUARINELLO, 2013: 11), ou seja, considerar que o autor e sua obra estão situados em um lugar no tempo e no espaço historiográfico, e que essas particularidades exerceram influência sob sua produção. Para este estudo, compreender os fragmentos em conjuntos narrativos é importante porque o debate persa precisa ser estudado dentro de seu próprio contexto, ou seja, como parte integrante da descrição de origem e ascensão de Dario ao trono da Pérsia momento no qual Heródoto nos constrói uma visão especialmente negativa da monarquia (tendo como base os governos de Cambises e do usurpador Smérdis). E, além disso, dentro do contexto da construção de uma espécie de identidade ateniense, muito ligada à democracia.

\footnotetext{
${ }^{19}$ Ou Guerras Greco-Pérsicas.
} 


\subsection{Teorias sobre o debate persa}

Heródoto conta que, cinco dias após a deposição do usurpador Smérdis, os conspiradores se reuniram para discutir o futuro da Pérsia. Três deles apresentaram suas opiniões acerca da situação: Otanes, o primeiro a falar, expôs críticas à monarquia e defendeu a distribuição do poder ao povo, argumentando em favor da isonomia e do revezamento dos ocupantes dos cargos públicos (ROY, 2012: 302); Megabizo, em seguida, reforçou as críticas ao governo de um homem só e atacou a democracia, expondo, por fim, os benefícios da oligarquia; e, por fim, Dario argumentou em favor da restauração da monarquia. Os quatro persas restantes nada disseram - apenas acompanharam a discussão e, em seguida, emitiram seus votos, consagrando o posicionamento de Dario.

O fragmento, descrito no terceiro livro das Histórias, capítulos 80 a 82, causa muita estranheza por colocar uma discussão tipicamente associada às póleis gregas em um contexto oriental (THOMPSOM, 1996: 53). Por conta disso, a passagem despertou o interesse de muitos estudiosos contemporâneos, que buscaram formas diversas para interpretá-la. A bibliografia sobre Heródoto III.80-82 é bastante extensa, e inclui trabalhos publicados há pelo menos 100 anos. Muitos destes estudos têm relevância teórica até hoje, pois foram capazes de indicar possíveis caminhos para melhor compreendermos o debate persa.

Alguns comentadores e estudiosos contemporâneos consideram o debate persa o trecho mais teórico do documento herodotiano, pois não apenas narra um suposto fato ocorrido em terras estrangeiras, mas porque também dá indícios da articulação de um pensamento político elaborado pelo autor, mesmo de uma forma não sistematizada - e que, ainda assim, ajudou a suscitar uma discussão teórica fundamental para a filosofia política ocidental. É justamente neste sentido que este estudo pretende contribuir: demonstrar que é possível interpretarmos o debate persa como uma teoria constitucionalista na obra de Heródoto, que de certa forma antecipou debates posteriores que seriam escritos por Platão, Aristóteles, dentre outros pensadores.

Conforme mencionado há pouco, a literatura sobre essa passagem é extensa. De um modo geral encontramos estudos sobre o fragmento divididos em duas linhas de pesquisa majoritárias. Ainda que existam outras interpretações possíveis, vamos abordar essas duas correntes porque são as mais representativas, em termos de volume de publicações, e porque dialogam de forma mais adequada com a nossa proposta neste 
estudo - de modo a questionar as limitações dessas correntes dominantes e inserir a nossa contribuição para a questão.

A primeira corrente teórica sobre o debate persa se debruça na investigação do chamado fato histórico em si, que basicamente reúne trabalhos cujo objetivo é procurar identificar a verdade empírica por trás do debate entre os três persas. Os pesquisadores dessa linha teórica adotam metodologias que possam negar ou comprovar ${ }^{20}$ a existência da discussão entre Otanes, Megabizo e Dario na Pérsia após a deposição do mago Smérdis, consequentemente, provando ou refutando o fragmento do livro III.

Esse parece ser o caminho mais adotado pelas pesquisas realizadas sobre o assunto, sobretudo na primeira metade do século passado. Isso é reflexo de uma tradição historiográfica positivista, que se assenta na busca pela verdade histórica dos fatos, tentando, de certa forma, separar a verdade da ficção. A maior preocupação desses estudos tomava como premissa que um fato narrado pelo historiador deveria ser classificado como real ou fictício, e, para isso, era necessário testá-lo. A partir daí, cabia ao pesquisador buscar subsídios teóricos e documentais (quando disponíveis) para refutá-lo ou dar garantias de sua plausibilidade. Ou seja, no caso do debate persa uma parte dos trabalhos investiu em tentativas de negar a reunião entre Otanes, Dario e Megabizo - inclusive alegando que o fragmento foi uma construção deliberada de Heródoto que servia a finalidades diversas; a outra parte, por sua vez, buscou ao menos algum indício que pudesse dar crédito a essa passagem das Histórias. De qualquer modo, trata-se de uma discussão bastante complexa e, ao mesmo tempo, carente de sustentação na maioria dos casos.

No geral, são estudos que procuram encontrar o ponto de cisão entre o Heródoto historiador e o Heródoto escritor de ficção. Reside aqui o problema referente à legitimidade do estatuto de Heródoto como historiador, mencionado por Condilo (2010).

Segundo Meneses Sousa, fica evidente que nesse tipo de estudo há

uma abordagem predominantemente positivista, que entende $\mathrm{o}$ conceito de fato histórico como sendo uma correspondência a uma verdade de fato, externa ao sujeito cognoscente, empiricamente

\footnotetext{
${ }^{20}$ Comprovar ou pelo menos encontrar meios que possam sustentar a possibilidade do debate persa ter de fato ocorrido - mesmo que, posteriormente, tenha sido helenizado ou mitificado por Heródoto em seu relato historiográfico.
} 
verificável e que se preocupa ainda em afirmar a história como ciência. (MENESES SOUSA, 2010: 19)

É possível afirmar que o resultado desse tipo de trabalho, comum à primeira linha de interpretação, pode ser considerado insuficiente para esgotar a questão devido à já mencionada ausência de documentos para refutar ou legitimar Heródoto (MENESES SOUSA, 2010: 16).

Há uma tendência geral entre os estudiosos de refutar o fato histórico - pelo menos na forma como Heródoto o apresenta. Nesses casos, a Inscrição de Behistun acaba sendo usada como uma espécie de contraprova que rejeita o debate persa. Trata-se de uma epígrafe autobiográfica escrita sob ordens de Dario após consolidar suas vitórias políticas e suas conquistas militares, entre 522 a.C. e 521 a.C. (BRIANT, 2002: 124), e compõe, junto das Histórias, a principal fonte referente à ascensão de Dario (MENESES DE SOUSA, 2010: 17).

No documento/monumento, segundo a concepção de Le Goff (2003: 526), o monarca narra sua própria versão para os fatos que o levaram a ascender ao poder. $\mathrm{O}$ documento inclui os atos que tomou para derrubar o falso Smérdis. Porém, não se trata de um documento historiográfico, mas sim de um discurso de poder do aquemênida, praticamente um monumento de propaganda ideológica de modo a mitificar a figura do rei-salvador, e, com isso, legitimar o seu governo.

Essa epígrafe foi gravada numa rocha localizada no atual Irã, e servia para mostrar aos viajantes o poder do império persa e as conquistas obtidas pelo Rei dos Reis. Para tanto, o documento apresenta o mesmo texto escrito em três idiomas diferentes: persa antigo, babilônio e elamita. Alguns autores, como Baghbidi (2009: 44), consideram esse o mais longo e mais importante documento da antiga Pérsia.

Do ponto de vista material, a inscrição foi feita em uma superfície aplainada da montanha, de 5,0 metros por 3,3 metros (BRIANT, 2002: 124), de modo que pudesse ser facilmente avistada pelas pessoas que circulavam na antiga estrada que unia a Babilônia e Ecbátana. Além do texto, a epígrafe é ilustrada com relevos que retratam os principais passos para a consolidação do governo de Dario. A figura em destaque na inscrição é o próprio monarca, localizado no lado esquerdo do quadro, mas olhando para a direita. Dario é retratado trajando vestimentas persas, com uma coroa na cabeça e um arco na mão esquerda, símbolos da nobreza. A mão direita está erguida e espalmada na altura do rosto. Atrás do rei estão dois servos, que, pelas roupas, também eram 
membros da aristocracia (ver figura 1). Um deles porta uma lança, e o outro segura um arco, reforçando sua posição junto à nobreza.

Nesta versão, Dario conta que o falso Smérdis ${ }^{21}$ conclamou o exército a se rebelar contra Cambises, que estava em campanha $(D b, 11)^{22}$, dizendo que era o legítimo filho de Ciro. Pouco a frente, na mesma epígrafe, Dario reconhece que teve ajuda de poucos homens para tomar o trono do mago, porém, num primeiro momento não revela seus nomes $(D b, 13)$. A identidade dos demais conspiradores só é relevada no fim da epígrafe, no parágrafo $68^{23}$. Entretanto, o aquemênida não dá mais detalhes da participação destes homens na empreitada contra o palácio de Susa: apenas elenca seus nomes e, em seguida, afirma que quando se tornou rei declarou proteção às suas famílias, como uma espécie de gratidão pelo apoio dado durante o processo de retomada do poder dinástico. Portanto, Dario não inclui nenhum debate sobre as formas de governo com a participação dos conspiradores - o que poderia indicar que Heródoto deliberadamente inventou a passagem.

Esse argumento, embora insuficiente, é apoiado por outra premissa, essa de ordem cronológica. É que a democracia teria surgido somente com as reformas de Clístenes em Atenas - o que inviabilizaria qualquer possibilidade desse regime político ter sido proposto anteriormente, ainda mais em um contexto oriental, distante da realidade política ateniense (a data comumente aceita para a instauração da democracia em Atenas é 508/507 a.C.).

\section{Figura 1: Inscrição de Behistun ${ }^{24}$}

\footnotetext{
${ }^{21} \mathrm{O}$ nome Smérdis está presente na obra de Heródoto. Na Inscrição de Behistun, o filho de Ciro é chamado de Bardiya. Outra diferença de nomes envolve o mago. Segundo Heródoto, o nome do mago que usurpou o poder era Smérdis, homônimo, portanto, ao filho de Ciro. Behistun, no entanto, diz que o nome verdadeiro do mago era Gaumata, que se passava por Bardiya.

22 Tradução do persa para o francês por Pierre Lecoq, na obra Les inscriptions de la perse achéménide (1997).

${ }^{23}$ Os nomes usados em Behistun são Vindarfarnah, Hutana, Gaubaruva, Vidarna, Bagabuxsa e Ardumanis, além do próprio Dario.

${ }^{24} \mathrm{O}$ painel principal da epígrafe retrata Dario I pisando em cima do peito de um adversário caído. Acredita-se que a figura pode ser uma representação do mago Gaumata, o falso Smérdis, de quem o aquemênida conquistou o trono persa. $\mathrm{O}$ usurpador aparece em posição de inferioridade, com as costas no chão e as mãos erguidas possivelmente em sinal de súplica ou misericórdia. Dos reis cativos, o mago é o único que foi retratado em uma condição tão humilhante. Ao lado direito da epígrafe, vê-se nove homens que estão com as mãos amarradas às costas e presos uns aos outros por uma corda atada aos pescoços. Provavelmente são os reis capturados pelo monarca durante o primeiro ano de seu governo, citados na própria Inscrição de Behistun. Todos teriam se rebelado contra o novo governante e foram derrotados em combate. Os nove rebeldes seriam: o elamita Açina; o babilônio Nadintabaira, que teria afirmado ser Nabukudracara, rei da Babilônia; o persa Martiya, que teria dado início a uma rebelião no Elam usando o
} 


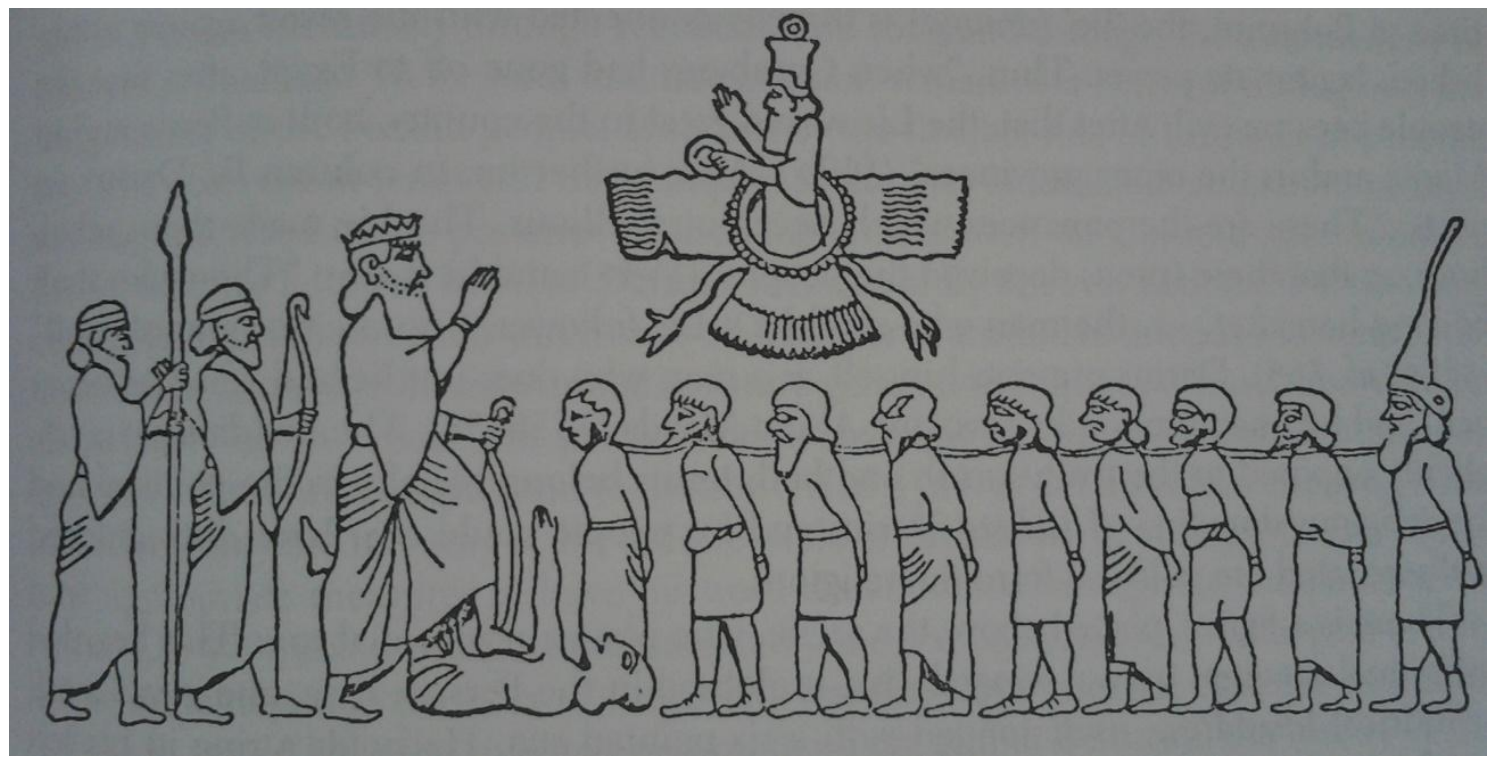

Fonte: BRIANT, Pierre. From Cyrus to Alexander : a history of the Persian Empire. Winona Lake: Eisenbrauns, 2002, p. 125.

Contudo, é importante fazer uma ressalva metodológica importante. Essa linha teórica, que compara o fragmento das Histórias com a versão presente na epígrafe de Dario, contrapõe dois documentos completamente distintos, uma vez que a obra de Heródoto é texto de narrativas historiográficas, enquanto a Inscrição de Behistun é um documento/monumento erigido com o propósito de legitimar o poder real do rei aquemênida. Logo, são bases documentais diferentes.

Ainda assim, é possível reconhecer que não sejam dois documentos completamente autônomos, pois Heródoto pode ter visto a epígrafe pessoalmente em

nome de Imani; o medo Fravarti, que após ser derrotado teve o nariz, as orelhas e a língua cortados, além de um olho cegado, antes de ser empalado - tudo porque tentou restaurar a dinastia da Média; o asgartiano Ciçantaxma, que teve um destino semelhante ao de Fravarti; o margiano Frada; o persa Vahyazdata; e o armênio Araxa, que foi empalado na Babilônia (Behistun, 52). Todos eles são representados em um tamanho menor que o de Dario, de modo a demonstrar inferioridade. Briant (2002: 125) indica que é possível distinguir cada um dos cativos pelas roupas. Desta forma, seriam eles, da esquerda para a direita: Gaumata (caído no chão), Açina, Nidintu-Bel, Fravartis, Martiya, Ciçatakhma, Vahyazdata, Arkha e Frada. O painel, porém, mostra um décimo personagem, na extrema direita. Esse último rebelde seria o líder cítio que também se insurgiu contra Dario. Ele se distingue dos demais pelo grande chapéu, que indica que ele pertencia à tribo saka tigraxauda (SCHMIDT, 1953: 38). Completando o documento, outros dois elementos são importantes. Acima de toda a ilustração encontra-se Ahura Mazda, deus a quem Dario atribui o sucesso de suas empreitadas - e mencionado diversas vezes na Inscrição. E, acima da cabeça do rei, um painel retangular traz sua titulação: grande rei, rei dos reis, rei da Pérsia, rei dos países, filho de Histaspes, neto de Arsames e aquemênida. Isso reforça a dinastia persa da qual Dario era herdeiro, em contraposição à antiga dinastia meda iniciada no passado por Deioces - que Smérdis/Gaumata conseguiu restaurar por um curto período de tempo, antes de ser deposto pelos conspiradores. 
suas viagens, ou mesmo a partir de cópias que provavelmente circulavam pela Pérsia e mesmo fora dela.

Embora seja mais comum encontrarmos a negativa do fato histórico, outros pesquisadores empregaram seus estudos positivistas justamente no sentido oposto. Esses autores admitem, ainda que de forma frágil e por vezes baseados em conjecturas, a possibilidade de que tal debate tenha ocorrido, mesmo que tenha sido de um modo diferente do descrito por Heródoto.

Uma das hipóteses é que a discussão entre os três persas pode ter sido "movida pela aristocracia persa que havia desmascarado o mago com a intenção de não estar sujeita a um poder centralizado, embora Heródoto o tenha helenizado" (MENESES SOUSA, 2010: 17). Essa defesa do fato histórico surge embasada na teoria de que o estado persa foi construído historicamente de forma descentralizada, com um poder central exercendo influência sobre estados tributários periféricos, que resguardavam certa autonomia para diversos aspectos da administração política (ASHERI: 2006: 4647), como a cunhagem de moedas, por exemplo. No entanto, quando Cambises sucedeu Ciro, o próprio Heródoto narra que o novo rei centralizou a política no império, cortando, inclusive, alguns privilégios que haviam sido concedidos pelo seu antecessor. Seria, portanto, a helenização de um debate cujo real propósito era expor as diferenças entre um modelo antigo de monarquia, criado por Ciro, e uma versão modificada por Cambises, que expunha o problema da descentralização-centralização (PELLING, 2002: 128-129).

Nesse contexto, é possível interpretar que a nobreza, ao perder não apenas o papel político de destaque, mas também os privilégios concedidos pelo governo central, buscou um modo de "lutar" pela restauração da política descentralizada. Cambises foi sucedido por Smérdis, que possivelmente manteve o mesmo tipo de política de centralização. Deste modo, com o sucesso da conspiração e a morte do mago, os aristocratas encontraram uma situação ideal para reivindicar um retorno àquela condição anterior ao reinado de Cambises, tornando as satrápias novamente dotadas de certa autonomia.

A hipótese, portanto, é que Otanes não teria, em seu discurso, proposto a criação de um estado democrático em si, seguindo os moldes atenienses que o conceito carrega, mas sim reivindicado a restauração da política de descentralização, com distribuição de poder entre os governantes de províncias (EVANS, 1981: 81), e não entre o povo. Não 
seria, então, uma democratização das instituições na Pérsia. Mas, em sua interpretação dessa tradição oral sobre a reivindicação dos privilégios, Heródoto poderia ter criado um "conto" (EVANS, 1981: 82) de que Otanes advogou em favor de uma política democrática. A discussão em si, dessa forma, poderia ter sido mitificada pelo historiador, ou até mesmo "traduzida" em termos que pudessem ser facilmente instrumentalizados para uma lógica helênica, servindo inclusive como propaganda política anti-Péricles, conforme argumenta Iriarte (2013: 101-102).

Essa proposta de interpretação do debate persa tem coerência argumentativa, sobretudo porque a figura de Cambises nas Histórias é a de um rei louco e sacrílego (ASHERI, 2006: 57), responsável por romper com uma série de tradições que datavam do governo de Ciro. No entanto, essa hipótese usada para comprovar o debate persa é o resultado de uma dedução com base em conjecturas, e não em fontes, pois não há outros documentos disponíveis para contrapormos à versão de Heródoto.

Em um importante texto de 1967, Neils Bailkey ${ }^{25}$ também se ateve a uma preocupação com o fato histórico, sugerindo que podemos pensar na possibilidade de existência de governos não-monárquicos no antigo oriente. Entretanto, falar em nãomonárquico não é o mesmo que pensar em uma democracia. São conceitos distintos. De acordo com a teoria de Bailkey, seriam, por exemplo, estados administrados a partir de um sistema no qual haveria um conselho de nobres deliberando a respeito das principais decisões políticas, porém, com a presença de uma espécie de poder central concedido a um indivíduo - que exerceria o cargo com funções limitadas. Um rei, por exemplo, governaria com poderes legalmente estabelecidos e limitados, e caberia a um grupo de conselheiros ajudá-lo a administrar esse estado.

O autor não trata da Pérsia especificamente, mas sim da Babilônia, e por analogia ele pode nos ajudar a compreender o debate persa por meio dessa perspectiva. Segundo Bailkey, a Suméria, por volta de 1595 a.C., era administrada a partir de uma monarquia baseada numa distribuição tripartite de poder: de um lado, havia um líder militar ocupando o cargo de governante central, porém, com uma atuação limitada às regras pré-estabelecidas; de outro, havia um conselho formado por anciões que compunham uma classe aristocrática; por fim, havia ainda uma assembleia de homens.

\footnotetext{
${ }^{25}$ Segundo Bailkey, é necessário rompermos com a ideia ultrapassada de que os gregos foram os criadores da política. Com isso, ele propõe pensarmos que os povos do antigo oriente também, evidentemente, construíram suas próprias instituições sócio-políticas, configurando diferentes tipos de comunidades políticas. Por essa perspectiva, ele sugere que não é absurdo pensarmos que civilizações no oriente conseguiram produzir experiências políticas baseadas em participação coletiva nas decisões - algo que um ocidental poderia considerar como similar a uma democracia.
} 
Todos os membros tinham um importante papel consultivo para os negócios de estado e trabalhavam conjuntamente (BAILKEY, 1967: 1212-1214), em um sistema semelhante ao governo misto.

Com essa explicação, o autor procura indicar que algumas localidades do oriente antigo presenciaram experiências políticas que previam uma ampliação das bases de participação política aos cidadãos na formação do governo, mesmo que houvesse um governante central com poderes limitados. Bailkey não fala em democracia no oriente, mas sim desconstrói a ideia de que a monarquia tradicional - comumente associada à tirania nas Histórias e em textos gregos de forma geral- seria a única forma de governo na região.

Esse argumento acabou servindo aos propósitos dos defensores da teoria do fato histórico do debate persa. Aplicando a ideia de Bailkey à interpretação do debate entre Otanes, Megabizo e Dario, Heródoto poderia ter tomado conhecimento desse tipo de experiência política no oriente, seja por meio da tradição oral ou por meio de documentos. E, a partir disso, o historiador teria construído sua versão, segundo a qual os persas debateram sobre qual seria a melhor forma de governo após a morte do usurpador do trono persa. Nesse caso, o historiador teria caminhado num sentido oposto ao que fizeram outros pensadores gregos de períodos posteriores, como Aristóteles, por exemplo $^{26}$, e narrado a possibilidade de que houve um debate constitucional no qual se discutiu a possibilidade de um governo relativamente participativo e distributivo na Pérsia - bem como havia na Suméria.

Para Bailkey, é plausível pensar dessa forma, inclusive porque os pesquisadores modernos dedicam-se pouco, em sua visão, ao estudo dos aspectos políticos presentes nas sociedades orientais, e, até por isso, partem do princípio de que a monarquia é a forma de governo única da região na Antiguidade (BAILKEY, 1967: 1230).

Por essa perspectiva, o debate persa indicaria a possibilidade das sociedades orientais terem constituído um governo distributivo e participativo, mesmo com restrições, mas com uma espécie de dirigente central coordenando as instituições políticas - de modo a manter a coesão. Isso, segundo o autor, reflete no momento em que Dario, segundo a narrativa de Heródoto, faz menção à liberdade garantida pelo governo de um só homem (BAILKEY, 1967: 1230-1231). Ou seja, a interpretação desse trecho, de acordo com o autor, nos levaria a compreender que, conforme a visão da

\footnotetext{
${ }^{26}$ Bailkey lembra a passagem em que Aristóteles classifica a ausência de democracia como uma falha de caráter, ao afirmar que o bárbaro é, naturalmente, escravo.
} 
monarquia defendida por Dario, o governante único teria plenas condições de governar de modo a garantir a liberdade da população - e não escravizá-la de forma tirânica e opressora, que é a marca conceitual da tirania grega.

Devemos reconhecer o esforço do autor em buscar um modo de legitimar o fato histórico em questão, porém, novamente, é preciso considerar que a ausência de documentação prejudica esse tipo de abordagem empiricista e positivista, e que a busca pela verdade histórica é praticamente inviável, além de ser um caminho que leva a um resultado extremamente frágil do ponto de vista teórico.

Ainda seguindo nessa mesma linha de interpretação, podemos mencionar o estudo de Dumézil (1984), muito bem indicado por Meneses Sousa (2010: 23-24), sobre a relação entre religião e poder. $\mathrm{O}$ autor buscou associar o debate persa com outro tipo de ritual, que pode ter servido como inspiração para a construção narrativa de Heródoto. Dúmezil, em primeiro lugar, indica que muitas sociedades orientais tinham ritos específicos para entronização dos novos governantes. Porém, há uma falta de conhecimento sobre eventuais rituais praticados nesse sentido pela dinastia aquemêmida $^{27}$. Ainda assim, ele acredita ser plausível que os persas tivessem algum tipo de celebração no ato de legitimação do poder real, de modo similar a outros casos documentados na Ásia.

Para elaborar essa teoria, Dumézil parte da ideia de que, na Índia, havia uma espécie de competição verbal entre representantes de diferentes classes sociais, de modo a alçar um homem à condição de governante. O ritual ocorria sempre que um novo rei chegava ao poder. Nesse contexto, homens, possivelmente aristocratas, se reuniam com esse novo governante para uma espécie de debate verbal. De um modo geral, o autor explica que o evento servia, ritualmente, para proteger o novo governante de possíveis adversários políticos que pudessem colocar seu governo em risco - ou mesmo que pudessem colocar em dúvida sua capacidade como administrador do estado. Seria, no limite, uma espécie de contribuição ritual para a glorificação do poder real.

Segundo essa teoria de Dumézil, Heródoto poderia ter tomado conhecimento de algum ritual persa de entronização deste tipo, que não conhecemos pela ausência de documentos. O relato pode ter chegado ao historiador por meio da tradição oral, por exemplo, ou mesmo através de fontes que posteriormente foram perdidas. A partir disso, Heródoto teria buscado um meio de levá-lo ao público grego, helenizando a

\footnotetext{
${ }^{27}$ A falta de conhecimento dos rituais de entronização se dá pela ausência de documentação sobre o assunto.
} 
narrativa do ritual como forma de torná-lo compreensível, num esquema metodológico similar ao sugerido por Hartog para as analogias. O resultado seria a discussão sobre as formas de governo.

Outra possibilidade é Heródoto ter se equivocado e compreendido que durante a elevação de Dario ao trono realmente foi organizada uma reflexão sobre os diferentes modelos constitucionais, e interpretado que se tratava de uma discussão para decidir qual forma de governo seria adotada pela Pérsia a partir daquele momento.

Essa teoria, em nossa opinião, também possui um argumento bastante frágil. A analogia com o ritual indiano mencionado pelo autor é interessante, inclusive porque vai à direção da ideia de Hartog sobre as analogias nas Histórias, mas a falta de documentação inviabiliza a comprovação da existência de algo similar em território persa. Logo, é uma boa hipótese, mas carente de sustentação material. Trata-se, portanto, de mais uma tentativa positivista de validar o estatuto histórico do debate persa.

Em 1963, Brannan já abordava as limitações desse tipo de análise positivista (BRANNAN, 1963: 427) e ainda alertava para outro argumento utilizado pelos defensores do fato histórico. Heródoto, no sexto livro das Histórias (VI.43), narrou que os persas toleravam as democracias na Jônia - região que vivia sob influência oriental. Alguns autores sugerem que isso indicaria uma espécie de simpatia, ou pelo menos compreensão a respeito do governo popular. Porém, Brannan refuta essa ideia por considerar que tolerar não significa necessariamente adotar o sistema democrático na Pérsia.

Nossa proposta é superar a armadilha dessa abordagem por considerar que o fato histórico mais importante não é a suposta discussão das formas de governo, mas sim que a passagem do debate persa foi narrada por Heródoto - seja ela verdadeira ou não (o que, para nós, é irrelevante). Nossa contribuição para a análise do fragmento visa, portanto, a uma análise dos efeitos da construção herodotiana para a tradição política ocidental, dando início a uma teoria constitucionalista a partir deste trecho das Histórias.

Além da corrente de análise do fato histórico, há ainda outra tradição nos estudos de Heródoto III.80-82, que busca compreender o debate persa a partir de sua estrutura literária. Essa linha de raciocínio configura uma das mais recorrentes sobre a passagem - não apenas por historiadores, mas também por especialistas em letras 
clássicas, que recorrem ao documento em si e ao suporte da gramática grega para estudar o fragmento e encontrar possíveis fontes de inspiração para o texto.

Seguindo essa lógica, alguns autores procuraram compreender marcas discursivas no texto que pudessem indicar uma possível inspiração textual para o debate persa. Essa abordagem, portanto, considera que os discursos de Otanes, Megabizo e Dario são externos à realidade persa, e que Heródoto se apropriou de outros textos conhecidos em sua época (e provavelmente perdidos posteriormente) para construir uma passagem anacrônica em seu contexto persa, mas próxima de uma realidade helênica do período - mais precisamente ateniense. Os discursos, logo, estariam fora do seu contexto espacial e cronológico. Cabe dizer que, independentemente de qualquer coisa, os persas retratados por Heródoto falam grego, e não persa, pois o texto usa uma estrutura argumentativa tipicamente ateniense, conforme identificou Murari Pires (2012: 184). Desse modo, supostamente o historiador teria tentado levar uma discussão ocorrida na Pérsia para o público helênico, entretanto, valendo-se de comparações com modelos políticos comuns à Grécia.

Alguns pesquisadores defendem a ideia de que a inspiração de Heródoto para a escrita dessa passagem partiu de elementos sofísticos, provavelmente oriundos de Protágoras. Trata-se de um contemporâneo do historiador, que atuou por muito tempo nas ágoras de Atenas, inclusive debatendo com Sócrates. O sofista trabalhava com base na chamada negativa de argumentos, que prevê a apresentação de teses e antíteses (BRANNAN, 1963: 428; MAASS apud MENESES SOUSA, 2010: 21). Para os autores, a fala de cada um dos três persas sustenta essa referência: Otanes indica as falhas da monarquia e em seguida os benefícios da democracia; Megabizo critica a monarquia e a democracia, para depois apresentar as vantagens da oligarquia; por fim, Dario critica a democracia e a oligarquia, e propõe a manutenção da monarquia por conta de diversas vantagens. Seria, portanto, uma lógica argumentativa similar à usada por Protágoras.

Essa hipótese, embora bastante debatida no século XX, foi posteriormente refutada por alguns autores ${ }^{28}$, como Lesserre (1976: 60-72), por considerar que dois discursos parecidos não representam, necessariamente, a reprodução de um modelo. Ou seja, o autor interpreta que o fato do debate persa ter uma estrutura argumentativa similar à forma usada por Protágoras não pode ser considerado uma inspiração direta.

\footnotetext{
${ }^{28}$ Outro argumento contrário à teoria de Maass é a ausência de alguns elementos característicos da sofística, como a argumentação simétrica.
} 
Além do argumento de Maass, é preciso mencionar ainda o famoso debate entre J. S. Morrison e A. W. Gomme, publicado na década de 1950 no The Journal of Hellenic Studies. Os autores utilizaram a publicação para criticar, replicar e treplicar os argumentos um do outro - demonstrando o quanto Heródoto III.80-82 é passível de análises controversas e polêmicas. Ambos, porém, detiveram-se, sobretudo, na estrutura textual do fragmento.

Morrison foi um dos primeiros pesquisadores a defender a ideia de que Heródoto instrumentalizou o debate persa numa tentativa de associar a posição monárquica de Dario com uma série de decisões políticas tomadas por Péricles em Atenas. Nessa perspectiva, o fragmento seria uma espécie de documento político-panfletário utilizado para insuflar a população ateniense contra uma de suas principais figuras públicas.

O crescimento da importância dos generais, e em particular a virtual dominação da vida pública ateniense por Péricles durante os 20 anos que precederam a guerra liderada pelos aquemênicas, levam para uma nova teoria do princípio de governo. A teoria de Clístenes tinha sido de que a cidade poderia fazer uma seleção indiscriminada e igual das pessoas que governariam por turnos. Pela nova teoria, o povo, ainda mantendo o poder supremo em mãos, é aconselhado e liderado pelos homens mais adaptados à liderança pelo talento ou posição. A teoria é certamente antidemocrática pela noção clisteniana" (MORRISON, 1950: 76)

Esse seria um indício, para Morrison, de que o exercício do poder popular havia mudado, ou porque encontrou novas condições para ser exercido ou porque a constituição de Clístenes já se mostrava insuficiente para dar conta das necessidades políticas de Atenas. A transformação resultaria na ascensão de Péricles dentro de um estado democrático - sem que, por conta disso, ele fosse considerado um "governante tirânico, aristocrata ou oligarca" (MORRISON, 1950: 76).

Nesse sentido, um trabalho recente de Iriarte (2013: 101-102) sugere que é possível identificar elementos da reflexão política do teatro ateniense na prosa herodotiana. Ela exemplifica com uma comparação entre as Histórias e a peça de Ésquilo sobre a vitória grega em Salamina, que retrata um fato histórico por meio de uma narrativa teatral. Enquanto Ésquilo representa simplesmente a vitória sobre um 
jovem rei, Xerxes, Heródoto tenta mostrar que a derrota persa no mar simboliza não apenas a queda militar de um soberano oriental, mas sim de todo um império e, também, de uma forma imperial de conduzir a política. A autora também sugere que a prosa narrativa herodotiana contém ecos de reflexão política provenientes do teatro ateniense, muito crítico à política praticada em Atenas no período de Heródoto. Sendo assim, retratar a "queda de uma política imperial”, explica Iriarte, seria uma espécie de advertência contra a maior potência surgida em território helênico após as Guerras Médicas, ou seja, Atenas (IRIARTE, 2013: 101-102), cujo principal líder interno era justamente Péricles.

Para associar Dario a Péricles, o discurso do persa teria sido escrito por Heródoto com uma linguagem típica dos tiranos gregos (MORRISON, 1950: 77). Assim, a estrutura literária empregada pelo autor associava a monarquia persa com a tirania das cidades gregas - talvez de modo a alertar os atenienses quanto aos resultados da prática imperialista vigente após o fim das Guerras Médicas.

Gomme, por sua vez, contra-argumentou que não há um compromisso em associar a democracia com a monarquia no debate, entretanto, concorda com Morrison ao afirmar que o texto demonstra que há uma experiência textual e política grega, e não persa, sendo retratada por Heródoto na composição do debate (GOMME, 1950: 77) independentemente de ter ou não o propósito de questionar o comportamento de Péricles em Atenas.

Ainda pela análise textual, fica evidente, para Morrison, que o Dario presente Inscrição de Behistun é bastante diferente do Dario da narrativa herodotiana, por se tratarem de dois personagens distintos. Nesse sentido, podemos analisar brevemente as conclusões do estudo de Bringman (1976), que de certa forma dialoga com o autor. Ele aponta nessa mesma direção, uma vez que, ao comparar os dois Darios, não vê nenhuma semelhança. A análise puramente literal, entretanto, mostra uma falha, pois é preciso considerar que se trata de dois documentos com finalidades distintas: o primeiro, uma epígrafe de legitimação de poder real, o segundo, um texto historiográfico, que ainda sofria influências da épica.

Ainda assim, o resultado do estudo de Bringman é interessante porque parece corroborar a posição de Morrison. O autor encontra semelhanças no discurso de Dario, reproduzido por Heródoto, com o de Péricles, narrado por Tucídides (Pelop., II.35-46), e conclui que há traços similares de pensamento político. Logo, para ele, a Atenas da era 
Péricles viveria aparentemente sob um regime democrático, contudo, tendo um homem à frente dos demais. Deste modo, não haveria nada, no debate constitucional, que poderia ser associado ao pensamento político persa, mas sim ao grego.

Nossa contribuição também procura superar as armadilhas dessa análise da estrutura literária do debate persa e focar em apenas um fato: o debate foi escrito e ele pode ser considerado o embrião de uma teoria constitucionalista helênica iniciada por Heródoto - embora ele não a tenha desenvolvido profundamente.

Neste primeiro capítulo traçamos um panorama geral do autor e de sua obra, apontando questões centrais para uma melhor compreensão do documento. No próximo capítulo, teremos a oportunidade de refletir diretamente sobre o pensamento político nas Histórias, mostrando como o contexto no qual o debate persa está inserido nos ajuda a interpretar a construção da monarquia/tirania e da democracia na concepção do autor - e como esses conceitos serão reforçados posteriormente, no debate entre Otanes, Megabizo e Dario. 


\section{Capítulo 2: O pensamento político nas Histórias}

\subsection{Reflexões sobre o pensamento político na obra de Heródoto}

No capítulo anterior, Heródoto e a escrita das Histórias, apresentamos um panorama sobre o autor de nosso estudo, além de termos discutido as críticas quanto ao estatuto histórico da obra herodotiana. Desse modo, tivemos a oportunidade de refletir sobre as possíveis interpretações que a historiografia nos propõe acerca das Histórias. A partir desta perspectiva, concluímos que o debate persa - bem como o restante da obra só pode ser adequadamente compreendido dentro de um contexto mais amplo, que inclui a época na qual o documento foi produzido e o próprio contexto no qual vivia o autor, ou seja, num momento central para a definição de uma identidade política grega (sobretudo ateniense) em contraposição à identidade estrangeira (principalmente persa) - além de contextualizar o fragmento dentro das narrativas de origem e ascensão de Dario ao poder.

Além disso, no primeiro capítulo analisamos as duas principais correntes teóricas que abordam o debate persa, fazendo uma revisão bibliográfica crítica sobre as obras que buscam refutar ou comprovar o fato histórico em si e sobre os trabalhos baseados no estudo da estrutura literária do texto herodotiano. A discussão nos leva a compreender que o diálogo entre Otanes, Megabizo e Dario foi alvo de constantes questionamentos no século passado, que representam, de forma mais ampla, o mesmo tipo de crítica a respeito do estatuto histórico da obra de Heródoto, e que, no século XX, o texto foi reabilitado por conta dos novos entendimentos das obras historiográficas da Antiguidade - que colocam as Histórias como uma obra com características próprias, que devem ser entendidas dentro de sua própria objetividade, e não como um mosaico desconexo.

Deste modo, concluímos inicialmente que ambas as correntes teóricas analisadas possuem resultados bastante interessantes, entretanto, apresentam limitações que não nos permitem superar a preocupação com o fato histórico em si - que é o nosso objetivo. O motivo para a limitação seria a ausência de documentos que sustentem a versão apresentada pelos autores, além da limitação epistemológica que afetava a história positivista, sobretudo na primeira metade do século passado - o que contribuiu para que esses estudos possam ser considerados insuficientes para analisar o fragmento III.80-82 de Heródoto. 
Agora, neste capítulo, teremos a oportunidade de analisar os principais conceitos antagônicos presentes no debate persa por uma perspectiva mais ampla nas Histórias, de modo a permitir uma interpretação aprofundada sobre o pensamento político de Heródoto expresso na passagem em questão - que resultará, diretamente, no modo como o autor articula as ideias narradas no debate entre os três persas logo após a deposição do usurpador Smérdis.

Uma primeira observação importante é que, em nossa interpretação, o debate persa só pode ser corretamente entendido dentro de um contexto de teoria política, pois a passagem coloca em oposição três modelos distintos de governo: a monarquia, que seria restabelecida após a vitória ideológica de Dario ante os outros dois nobres; a democracia, proposta por Otanes como forma de pôr fim à arbitrariedade do governo de um homem só por meio de um sistema de distribuição de poder através do sorteio; e uma espécie de meio termo entre essas duas constituições, a oligarquia, defendida por Megabizo como a única capaz de refrear os excessos do monarca e, ao mesmo tempo, evitar a insolência da multidão dotada do poder.

Essa análise nos indica que monarquia e democracia são modelos políticos antagônicos na obra herodotiana, enquanto o governo oligárquico serviria como uma espécie de ponto de equilíbrio na distribuição de poder, instituindo um modelo constitucional com um número limitado de participantes, porém, evitando que apenas um concentrasse todo o poder consigo, ficando, portanto, em um estágio intermediário de distribuição de poder político no estado.

Deste modo, nos parece apropriado pensar que a tradição adjacente ao debate persa coloca dois grandes modelos políticos em oposição, ou seja, a tirania/monarquia e a democracia. Segundo Roy,

O debate constitucional persa em Heródoto prova que esse tipo de classificação (das formas de governo) era familiar no fim quinto século, e que os gregos já descreviam essas constituições em termos de como o poder era distribuído e também como eram feitas as distinções entre o governante racional e impulsivo, o mau governante. (ROY, 2012: 298-299)

Podemos partir da premissa de que havia, provavelmente, uma tradição política existente na Grécia no período, e que ela pressupunha um debate sobre as diferentes categorias de governo, classificando-as de acordo com a distribuição do poder e do uso 
desse poder. É certo, entretanto, que Píndaro já havia prenunciado a questão, ao utilizar o termo tirania e, em seguida, mencionar - mas sem tipificar - estados administrados pelo povo e por homens de habilidade ${ }^{29}$.

Mas, em todos os modos de governo, um homem de fala simples eleva-se em primeiro lugar, seja na corte de um tirano (tirannídi), ou sob a multidão turbulenta (lábros stratós), ou onde o estado é governado pelos homens sábios (sófoi). (PÍNDADO, Pyth, II.86-88)

O fragmento ajuda a sustentar a tese de que o debate das formas de governo já era conhecido no período anterior a Heródoto. Porém, Píndaro apenas menciona a questão, sem discuti-la ou questionar os aspectos políticos acerca das constituições. Não há, nesse caso, uma sistematização acerca das características de cada constituição implícita no trecho citado. É preciso destacar que Píndaro não era historiador e nem filósofo e, como poeta, não tinha nenhum compromisso que não fosse a própria poesia em si - o que justifica o motivo de não ter se preocupado em analisar os governos. O texto mencionado há pouco, inclusive, é uma ode aos Jogos Píticos, festival panhelênico celebrado em Delfos. O documento fala de Hierão de Siracusa, vencedor de uma corrida de quadrigas na competição.

Logo, podemos afirmar que até Heródoto III.80-82 não há registros da teorização acerca dessa questão na historiografia ocidental. Deste modo, esses são os indicadores que norteiam o pensamento do historiador nessa passagem.

Em segundo lugar, devemos destacar o fato de que essa discussão ganha um destaque especial em Atenas, e coloca em conflito duas formas de governo antagônicas que integram a história política ateniense de um período próximo à escrita das Histórias: a tirania e a democracia. Esse problema histórico está situado na segunda metade do século VI a.C., época de transição entre as três décadas do governo de Pisístrato e seus filhos, e a criação da constituição de Clístenes, cuja principal proposta era a instauração da isonomia, ou seja, da igualdade perante as leis. São, portanto, dois modelos políticos situados em lugares e em momentos específicos. Logo, democracia e tirania são dois conceitos que devem ser tratados como fenômenos políticos e históricos

\footnotetext{
${ }^{29}$ Por homens de habilidade possivelmente podemos compreender como aristocratas, ou seja, os melhores.
} 
concretos, e Heródoto usa seu texto para classificar essas formas de governo. Isso, posteriormente, teria reflexos no debate persa e na articulação que o autor elabora a partir da reprodução dos supostos discursos dos três nobres.

Portanto, em nossa interpretação, esse embate político e ideológico norteia a discussão do juízo valorativo de Heródoto sobre as formas de governo. Entretanto, é preciso sempre pensar que esse problema está ligado a uma realidade comum à Atenas, a pólis mais documentada na Grécia e aquela que parece ter dado um especial contributo para a formação de uma identidade política grega - ao menos para a visão contemporânea. As fontes e documentos disponíveis, como Heródoto, Aristóteles, Tucídides, além de alguma documentação epigráfica, ligam a cidade-estado a um acalorado debate entre a tirania dos pisistrátidas e a instauração da democracia por Clístenes. Essa perspectiva é importante porque nos parece que toda a discussão envolvendo os pontos de vista polarizados do debate, ou seja, as argumentações de Otanes e Dario, sofre influências dessa tradição política - que certamente influenciou Heródoto e seus contemporâneos. Essa discussão, aliás, se confunde com a própria história política e social ateniense do final do século VI a.C., e tem reflexos para outras póleis.

Essa oposição entre democracia e tirania representa não apenas um embate entre ideias políticas distintas, mas envolve principalmente uma discussão entre as distinções culturais entre povos estrangeiros. Conforme já mencionamos, as Guerras Médicas nos ajudam a pensar que há, nas Histórias, um problema central de construção de uma espécie de identidade comum aos helenos, que se opõem, consequentemente, à imagem do outro, do bárbaro. Segundo Gruen (2011: 1), a alteridade serve justamente como forma de tratar o outro como inferior. As variadas concepções para as formas de governo servem como elemento para a construção dessa imagem. No caso dos persas, eles são retratados como pessoas que viviam sob regimes despóticos e em condição servil (2011: 9), ao contrário dos helenos, orientados pela liberdade e pela democracia. Assim, o antagonismo entre os modelos políticos funciona, nas Histórias, como um ponto de diferenciação entre a identidade helênica e a bárbara. Deste modo, a vitória nas Guerras Médicas simboliza, na obra, a vitória da liberdade e da democracia ante o despotismo bárbaro (2011: 10-11).

Essa discussão remonta à própria formulação do debate contemporâneo acerca da formação das identidades. Hall, no primeiro capítulo de sua obra, explica que até a Segunda Guerra Mundial (cujo início data de 1939) os especialistas costumavam tratar 
das identidades a partir de teorias derivadas de um pensamento oriundo do romantismo (HALL, 1998: 1-2), cuja âncora era a busca pelo passado heróico das nações. Isso, de certa forma, justificaria porque determinado povo deveria ser considerado "superior" ao outro, assumindo que certas características são determinantes e imutáveis (que, consequentemente, levavam a essa "superioridade"). Entretanto, os estudos identitários sofreram uma série de transformações a partir do recrudescimento dos conflitos étnicos na segunda metade do século passado. Deste modo, as identidades deixaram, pouco a pouco, de ser compreendidas como o resultado de formações naturais entre indivíduos na sociedade - quase que de forma orgânica e biológica - para serem interpretadas como o reflexo de construções sociais mais complexas, que não são monolíticas e que podem sofrer modificações a partir de diversas condições sociais e do próprio processo histórico em si.

Desta forma, a leitura de Hall refuta que cultura e idioma sejam fatores suficientes para a formação de uma identidade comum entre os indivíduos ou grupos. Ao invés disso, o autor propõe que as identidades são socialmente construídas, a partir dos "discursos escritos e falados" (HALL, 1998: 2). Assim, pertencer a um grupo específico é uma construção artificialmente criada com o uso de ferramentas discursivas, que mudam de acordo com o tempo e com os autores envolvidos no processo.

Dentro deste entendimento, devemos considerar que as Histórias compreendem uma obra escrita discursiva, na qual o historiador expõe certos valores atribuídos ao seu próprio grupo, em contraposição ao grupo "rival", de modo a identificar características particulares de ambos. Como ferramenta utilizada para demonstrar essa diferença - e consequentemente expor as distinções identitárias - Heródoto revela a existência de modelos políticos antagônicos, que dentro deste contexto podem ajudar a consolidar a diferenciação entre o "eu" e o "outro". O elemento político como fator de distinção identitária reforça, portanto, o "dispositivo de rotulagem" (SCHNEIDER, 2004: 98) da própria identidade étnica em si.

A partir dessa interpretação, é possível afirmar que o pensamento político de Heródoto é permeado, sobretudo, por essa dualidade entre democracia e tirania, simbolizando por sua vez o conflito entre liberdade e autocracia, razão e arbitrariedade, (GRUEN: 2011: 21), livre escolha e "compulsão tirânica", sistema livre contra 
imposição (GRUEN: 2011: 22) ${ }^{30}$. Ou seja, trata-se de uma comparação entre os valores gregos/atenienses do período democrático e o suposto despotismo persa - a partir, evidentemente, de uma perspectiva helênica influenciada pela lógica da cidade-estado do século V a.C. (sobretudo Atenas). Vlassopoulos (2013: 1) argumenta que o conflito não se restringe a mostrar a diferença entre gregos e bárbaros, mas também esboça uma distinção entre leste e oeste, pela qual os helenos são retratados como os criadores

"da democracia, liberdade de pensamento, ciência, filosofia, drama e arte naturalista, e cujas obras literárias continuam como a fundação da literatura ocidental; o mundo do leste, o mundo das pessoas que os gregos descreviam como bárbaros, é um mundo completamente diferente, caracterizado pelo despotismo e teocracia, e a ausência de todos os valores gregos" (VLASSOPOULOS, 2013: 1)

O discurso da alteridade, no fim, serve para enunciar o outro como diferente (HARTOG: 1999: 229), que de certa forma conduz os indivíduos ao complexo fenômeno de incompreensão mútua entre povos estrangeiros (DEMONT, 2013: 40). Heródoto trabalha, nesse sentido, com a apresentação de argumentos opostos, que ajudam a reforçar essa distinção, tais como grego e não-grego, por exemplo. Isso nos remete ao fato de que as diferença entre helenos e não-helenos é, portanto, construída a partir dos processos políticos (SCHNEIDER, 2004, 98) em elaboração não apenas pelo historiador, mas também pela própria sociedade ateniense em si - que desvinculam a formação dos grupos étnicos e da própria identidade da antiga lógica dos comportamentos culturais. E esses processos são construídos gradativamente, emergindo no período arcaico e encontrando seu principal momento de definição nas Guerras Médicas (VLASSOPOULOS, 2013: 34-35).

\footnotetext{
${ }^{30}$ Diversas passagens das Histórias são mencionadas por Gruen para exemplificar essa construção do pensamento político herodotiano, que contrapõe os valores helenos e estrangeiros nesse processo de construção de identidade. Dois, em especial, merecem ser citados. O primeiro remete ao diálogo entre Xerxes e Demaratos, no contexto da Segunda Guerra Médica, no qual o espartano afirma que os lacedemônios resistiriam até o fim por lutarem pela manutenção da condição de homens livres e pelo respeito à nomos, e não por serem servos de um governante. Em contrapartida, o espartano afirma que todo persa, mesmo os oficiais de alta patente, serviam ao monarca, e podiam ser considerados escravos desse sistema (VII.101-105). A segunda passagem refere-se a uma atitude considerada não-civilizada: a decapitação do rei espartano Leônidas, após a derrota nas Termópilas (VIII.238). Pouco depois, Pausânias teria a oportunidade de fazer o mesmo com Mardônio, porém, se recusou a violar o cadáver do inimigo vencido por considerar que tal atitude seria apropriada a um bárbaro, e não a um grego (IX.78-79).
} 
Do ponto de vista político, o historiador de Halicarnasso opõe democracia e tirania, o que nos servirá para analisar o debate persa como um choque ideológico entre instituições políticas antagônicas, que nos apresenta o fenômeno do barbarismo como sendo a definição do que é o oposto da moral e da cultura grega (VLASSOPOULOS, 2013: 191). É com o suporte desse ponto de vista polarizado que Heródoto elabora uma teoria acerca das formas de governo.

Por último, antes de analisarmos as duas constituições antagônicas, além da oligarquia como espécie de governo intermediário entre elas, é importante ressaltar que os termos monarquia e tirania são utilizados em muitos momentos como sinônimos, ou seja, os autores antigos - o que inclui Heródoto - não diferenciavam os governantes únicos entre legítimos e ilegítimos, respectivamente. Para eles, monarca e tirano poderiam ser considerados governantes únicos. Essa divisão valorativa seria sistematizada no século seguinte por Aristóteles, na Política. O historiador de Halicarnasso, por sua vez, trabalhou do mesmo modo como outros pensadores da época, misturando frequentemente os dois conceitos. É comum, por exemplo, monarcas que chegaram ao trono por conta dos laços de sangue com o rei anterior serem tratado da mesma forma a outros que ascenderam a partir de golpes de estado. Entretanto, de forma não-sistematizada é possível interpretar que Heródoto já conhecia esse tipo de distinção e, além disso, usou argumentos implícitos no debate persa para esboçar uma distinção valorativa, conforme veremos mais detalhadamente no capítulo seguinte desta dissertação.

Deste modo, para analisarmos o pensamento político nas Histórias, é necessário, neste momento, nos dedicar à análise desse embate ideológico entre tirania/monarquia e democracia para compreender o significado desse conflito na obra - e, consequentemente, compreender também a teoria das formas de governo inaugurada na historiografia, por Heródoto, com sua teoria constitucionalista. Entretanto, é preciso dizer que este trabalho não é um estudo específico sobre a monarquia, tampouco sobre a democracia ateniense, mas sim sobre o debate persa. Porém, um estudo satisfatório desse episódio depende de uma análise prévia sobre o pensamento político herodotiano acerca das constituições antagônicas, para somente depois aplicarmos essas análises à passagem III.80-82.

Sendo assim, vamos, neste momento, analisar a visão de Heródoto acerca das tiranias, de modo a compreender como o autor constrói a visão negativa dos reis/tiranos 
persas nos antecedentes do debate, ou seja, no próprio livro III das Histórias. Em seguida, vamos analisar o modelo antagônico, a democracia, mas dentro do contexto que provavelmente influenciou o historiador: a realidade ateniense. Por fim, faremos uma breve exposição a respeito da oligarquia/aristocracia, também num contexto político de Atenas, para mostrarmos alguns indícios do juízo valorativo de Heródoto sobre a forma de governo considerada um meio termo entre tirania e democracia.

Após as interpretações isoladas sobre essas formas de governo será possível expor a contribuição deste estudo sobre o debate constitucional persa, a partir da análise da teoria política. 


\subsection{O governo de um nas Histórias}

A visão de Heródoto a respeito das tiranias resultou em uma grande produção acadêmica no século passado, de modo a dividir os autores a partir de algumas correntes interpretativas distintas. Tantos estudos só foram produzidos nos últimos 100 anos por conta da importância do tema: há, nas Histórias, uma constante presença dos tiranos nas narrativas herodotianas, tanto em contexto helênico quanto estrangeiro. Muitos dos conjuntos narrativos que compõem a obra descrevem grandes líderes, ocidentais e orientais, associados à tirania e à monarquia, como o lídio Creso, o coríntio Periandro e os persas Ciro, Cambises e Dario - responsável por restaurar a dinastia na Pérsia e um dos debatedores em III.80-82. Logo, a descrição de governos monárquicos/tirânicos compõe uma relevante parcela dos lógoi da obra, fato que atrai a atenção de muitos estudiosos de Heródoto ${ }^{31}$.

O historiador, ao que parece, tinha um especial interesse por essa questão. Precisamos ter em mente duas coisas sobre isso. A primeira é que a própria biografia do autor nos ajuda a compreender a influência dos tiranos em sua vida e obra, uma vez que ele próprio foi exilado de Halicarnasso por conta de problemas com o governante local e pelo fato de ter vivido em um momento de desenvolvimento de uma espécie de identidade helênica ante uma identidade estrangeira. Ou seja, a diferença entre a democracia da pólis e uma suposta tirania dos estados tidos como bárbaros era um dos elementos identitários que distinguia o grego e os outros, e certamente era um assunto dominante no ocidente grego do período - que provavelmente afetou diretamente a vida do escritor de Halicarnasso. Em segundo lugar, é preciso reforçar que a tirania por vezes é confundida com a monarquia na narrativa, ou seja, as figuras do rei legítimo e do governante despótico são retratadas a partir de uma mesma perspectiva pelo historiador. No debate persa, por exemplo, nenhum dos três nobres diferencia claramente o governo monárquico do tirânico ${ }^{32}$, conforme veremos mais detalhadamente em seguida. É mais um reflexo do pensamento político de Heródoto.

\footnotetext{
${ }^{31}$ Uma das descrições mais veementes de tirania presente nas Histórias está em V.92, quando o historiador classifica essa forma de governo como injusta e sanguinária, retratando a tirania como um estágio anterior de evolução política (IRIARTE, 2013: 97). Nesse mesmo fragmento o historiador cita três tiranias célebres da Grécia Arcaica: a dinastia de Periandro, de Corinto; Pisístrato e seus filhos, de Atenas; e o regime de Trasíbulo, de Mileto.

${ }^{32}$ Não há um juízo valorativo dando conta de que uma forma de governo é legítima e a outra ilegítima. Heródoto, em alguns casos, classifica o governante como um tirano, mas aponta elementos positivos em sua personalidade e em suas atitudes. Veremos mais sobre essa questão ainda neste capítulo.
} 
Partindo para uma análise inicial da tirania, é possível considerar que o termo surge nos textos gregos em algum momento do século VII a.C., cuja origem é atribuída possivelmente ao poeta Arquíloco ${ }^{33}$. A primeira menção seria uma referência à Giges, usurpador do trono da Lídia, classificado no poema ${ }^{34}$ como um tirano ascendendo ao poder. Independentemente de possíveis análises valorativas a respeito do governante, o que nos importa é que ele indica, pela primeira vez, o uso do termo em questão. A partir de então, outros autores helênicos passaram a empregar a mesma tipologia para se referir a casos e a situações muitas vezes antagônicas entre si - o que sugere que a confusão conceitual entre monarquias e tiranias é muito antiga e surgiu bem antes de Heródoto.

Seguindo uma linha cronológica, depois de Arquíloco a preocupação com o governante único das póleis passou a ocupar um lugar de destaque em outras obras da literatura grega, como em Alceu ${ }^{35}$, na tragédia, como em Ésquilo ${ }^{36}$, chegou à narrativa historiográfica de Heródoto e Tucídides e, posteriormente, foi discutida nos textos filosóficos de Platão e Aristóteles ${ }^{37}$. Neste longo período, portanto, a palavra "tirano" e o significado que ela representa foi utilizado ora para criticar a legitimidade do governante, ora para ressaltar a glória de suas conquistas - provando ser visões antagônicas acerca do mesmo conceito.

Alguns autores, como o supracitado Aristóteles (Pol., III.VIII.1), apresentam a tirania a partir de uma conotação extremamente negativa, ressaltando que esse tipo de governo é uma degeneração da legítima monarquia, na qual o governante governa

\footnotetext{
${ }^{33}$ Arquíloco foi um poeta lírico nascido na ilha de Paros, provavelmente em uma prestigiada família local. O autor viveu no século VII a.C. Boa parte da obra de Arquíloco foi perdida, nos restando apenas alguns fragmentos, dentre os quais se destaca o famoso poema sobre Giges, rei da Lídia. O poeta é considerado uma grande inspiração para autores romanos posteriores, como Horácio.

${ }^{34}$ O poema ao qual nos referimos é o fragmento número 19 , no qual o poeta se refere à Giges: "Não me preocupam as coisas de Gyges, rico em ouro, nem ainda me persegue a cobiça, nem invejo as obras dos deuses, ou amor pela grande tirania; isso longe está dos meus olhos." (tradução de ROCHA MENEZES, Luiz Maurício Bentim da. Nova interpretação da passagem 359d da República de Platão, in: Kriterion: Revista de Filosofia, vol. 53, n. 125, 2012. Para outras informações sobre Arquíloco e o fragmento 19, ler FERREIRA, Moisés Olímpio. A lírica grega arcaica: Arquíloco de Paros - estudo do fr. 19, in: Alétheia - Revista de estudos sobre a Antiguidade e Medievo, vol. 1, 2009.

${ }^{35}$ Alceu foi um poeta nascido em Mitilene, na ilha de Lesbos, na segunda metade do século VII a.C.. O autor tinha uma origem familiar aristocrática e esteve envolvido em disputas políticas na pólis. A figura de Alceu é associada à do tirano Pítaco, com quem ora manteve relações de aliança, e ora de inimizade. Muitas de suas odes tinham um forte caráter político.

${ }^{36}$ De acordo com McGlew, Ésquilo é uma boa fonte trágica para as tiranias arcaicas. Para mais informações, ler MCGLEW, James F. Tyranny and political culture in Ancient Greece. Londres: Cornell University Press, 1993.

${ }^{37}$ A perspectiva de Platão e Aristóteles quanto às formas de governo, em especial à democracia, é influenciada pelo fato de terem escrito suas obras já no século IV a.C., quando puderam analisar a derrocada do modelo democrático causada pelas consequências da vitória espartana na Guerra do Peloponeso e, por conseguinte, na mudança do cenário político da Hélade.
} 
orientado para o bem comum da sociedade e, por isso mesmo, administra o estado de acordo com as leis, não tomando decisões com base em arbitrariedades. A partir desta interpretação, é possível distinguir um governante legítimo de um ilegítimo, que ocupa o trono e governa exclusivamente para atender seus próprios interesses. Essa é uma característica tipicamente associada ao despotismo que perdura até a contemporaneidade. Contudo, em outros textos gregos a conotação é positiva, como o retrato de Gelão de Siracusa presente na obra do poeta Píndaro, na qual o tirano é descrito como um governante popular (LEVY, 1993: 8).

A presença constante da tirania nos textos gregos, em especial nas Histórias, resultou em estudos que podem ser divididos em três abordagens principais, que em alguns casos remetem à crítica ao estatuto histórico da obra herodotiana - que precisa ser superado.

A primeira linha interpretativa claramente identificada nas pesquisas sobre essa forma de governo indica a presença de diversos elementos característicos da tragédia ática nas Histórias, como uma espécie de paralelo entre o destino dos heróis míticos e o dos reis/tiranos. Autores como Vernant e Vidal-Naquet, dentre outros, destacam que a descrição dos tiranos normalmente aponta para um destino similar ao dos personagens da literatura grega, como Édipo e Periandro - ou seja, para um destino trágico, que resguarda, inclusive, semelhanças físicas entre homens e deuses (2008: 180-181). Desse modo, essa abordagem destaca a presença de elementos da Grécia Arcaica na obra herodotiana, bem como a influência da tragédia e da épica para a construção do arquétipo dos governantes.

Isso remete à presença dos elementos míticos na obra herodotiana, já discutido brevemente no capítulo anterior desta dissertação, e também à influência que a poesia épica (seja ela homérica ou de outros autores) exerce sobre a narrativa historiográfica em seu momento de emergência. No geral, os estudos desta primeira linha de pesquisa estão mais centrados na análise textual da obra.

A segunda abordagem, bastante significativa em termos de volume de publicações, busca analisar a função desempenhada pelos reis presentes nas Histórias de modo a verificar sua importância não apenas como governantes, mas também a partir de uma leitura mais conceitual - que por vezes poderia remeter ao trabalho do próprio historiador. A partir dessa interpretação, alguns autores argumentam que é possível considerar que Heródoto, em muitas ocasiões, retrata os tiranos como personagens 
dotados de sabedoria, que buscam constantemente o conhecimento e se valem de técnicas de investigação (como fazem os historiadores) para apurar os fatos mais diversos que envolvem o trabalho de governar. Dessa forma, eles teriam a capacidade de discernir a verdade da mentira e, a partir disso, tomar decisões de uma forma considerada mais acertada.

Esse, segundo Christ (1994: 167), é um papel semelhante ao desempenhado pelo próprio historiador ${ }^{38}$ : uma pessoa que vai a campo para investigar determinado acontecimento ou fenômeno, de modo a buscar compreender a realidade a sua volta e reconstruí-la de forma fidedigna ao verificado, para, posteriormente, reportá-la aos demais.

Sob esse aspecto, os reis e tiranos nas Histórias podem desempenhar o papel de administradores da justiça em seus estados, uma vez que são dotados da capacidade de analisar os fatos com competência para em seguida julgá-los e, com isso, tomar as decisões corretas. Um exemplo notório, utilizado por diversos autores para exemplificar essa abordagem, como Gray (2001), é a narrativa das desventuras de Árion em Corinto (Hist., I.23-24) e seu encontro com Periandro, o tirano local.

De acordo com o texto herodotiano, o personagem era um músico consagrado em seu tempo, e vivera a maior parte da vida na corte de Periandro, em Corinto, onde chegou a ensinar a arte dos ditirambos (Hist., I.23). Em determinado momento, viajou para as cidades gregas da Itália e na Sicília, na tentativa de fazer fortuna. Na volta da viagem, após concluir seus objetivos, enfrentou problemas que quase o levaram à morte. Árion embarcou em uma nau coríntia, que o levaria a Taras, e no meio do trajeto foi pego pelos tripulantes - que o ameaçaram lançar ao mar para roubar seu dinheiro. Após tentar dialogar com os marinheiros, conta Heródoto que Árion foi salvo por um delfim, que o levou a Corinto, onde contou sua história a Periandro (Hist., I.24). O animal é inserido na história porque ele seria o agente de alguma divindade (GRAY, 2001: 13).

Após ouvir o relato do aedo, o governante esperou pela chegada dos marinheiros e os interpelou acerca da verdade. Eles inicialmente mentiram, dizendo que o músico ainda estaria na Itália. Porém, após Árion aparecer diante deles, confessaram a verdade. Portanto, como faria um historiador, o tirano escutou a versão apresentada pelo aedo e, em seguida, teria buscado as testemunhas para construir sua própria interpretação - não apenas acreditado na versão inicial da vítima. Ou seja, esse entendimento do tirano

\footnotetext{
${ }^{38}$ Christ não se refere apenas a Heródoto, mas sim aos historiadores de modo geral.
} 
como um "investigador" vai à mesma direção da construção de um tipo ideal do tiranosábio, conforme nos aponta David Asheri (2006: 31).

Por fim, a terceira e última abordagem a respeito da tirania nas Histórias - e a mais relevante para o nosso estudo - se preocupa em analisar uma espécie de preferência política de Heródoto quanto aos reis/tiranos retratados em sua obra. São estudos que não se preocupam com a busca do fato histórico ou com o estatuto histórico do autor, mas sim com a identificação de possíveis juízos valorativos em sua descrição dos tiranos. De certa forma, os que se alinham a essa metodologia procuram analisar elementos discursivos que possam indicar ou sugerir um valor atribuído ao tirano retratado na passagem, como sendo bom ou ruim, por exemplo; e a tirania como uma forma de governo positiva ou negativa. Essa é uma linha de pesquisa interessante, pois nos ajuda a pensar como nosso autor analisa e classifica as monarquias persas, postura que futuramente seria estendida ao debate persa a partir das críticas de Otanes e Megabizo ao governante único - sobretudo a partir daquele modelo da administração de Cambises e do usurpador Smérdis -, e pela argumentação feita por Dario.

Entretanto, a análise valorativa das tiranias é uma tarefa complexa, pois ela é passível de uma série de ponderações distintas. Deste modo, diversos autores chegaram a conclusões diferentes sobre os valores atribuídos por Heródoto às tiranias. Uma delas reúne pesquisadores que vêem uma neutralidade na descrição dos tiranos e das tiranias nas Histórias. Autores como Kenneth Waters (1971) e Stewart Irving Oost (1976) advogam em favor da neutralidade por considerarem que o historiador apresenta aspectos tanto positivos como negativos nas tiranias, justificando assim a ausência de um juízo de valor por parte de Herótodo. Para Oost, a grande questão é que no período arcaico as palavras rei e tirano eram usadas de forma genérica, porque "o termo tirano meramente significava governante, sem necessariamente nenhuma conotação pejorativa" (1976: 224).

Outro grupo de autores, por sua vez, defende que Heródoto constrói uma visão positiva acerca dos tiranos, que muitas vezes são retratados como reis pensadores (FLORY, $1987^{39}$ ), novamente numa teoria que lembra os arquétipos ideais sugeridos por Asheri (2006). Esse seria, segundo essa perspectiva, o retrato de um rei-filósofo. É importante pensarmos que essa linha de interpretação não defende a positividade como elogio a eventuais ações violentas por parte dos tiranos, mas sim por serem governantes

\footnotetext{
${ }^{39}$ Ideia expressa, sobretudo, no quarto capítulo do livro, intitulado Freedom and discipline: cruel tyrants and philosopher kings.
} 
pensadores. A ideia, segundo Dewald, é que indivíduos como Deioces, Pisístrato, Dario e Psarmético ilustram a imagem do bom governante único, porque suas ações resultaram em bons governos - mesmo que muitas vezes a força tenha sido usada para comandar o Estado de forma apropriada, numa concepção de que nem sempre o uso da força corrompe o líder político (DEWALD, 1990: 62).

Por último, há os pesquisadores que consideram como sendo negativa a visão das tiranias na obra herodotiana. O motivo é que esse tipo de governante costuma ser retratado com características tipicamente associadas ao conceito mais contemporâneo de tirano, segundo o qual

tirania é uma forma degenerada de governo, tanto em sua forma ilegal de governar (tirania quanto ao modo de exercício do poder), quanto na sua forma ilegítima (tirania no respeitante ao título de aquisição de aquisição do poder, ou usurpação). (...) Como forma de governo, o despotismo caracteriza-se pelo monopólio da organização burocrática que (...) constitui a mais terrível ameaça para a liberdade do homem. (BOBBIO, 1998: 340, 347)

Deste modo, o governante é retratado como alguém que toma decisões arbitrárias às regras estabelecidas e desrespeita os princípios do bom comportamento presentes na moral grega, expondo seus defeitos (GAMMIE, 1987: 195), como o uso de violência contra os súditos, o descumprimento de leis legitimamente propostas e aprovadas, chegada ao poder por meio de vias despóticas (como golpes de estado), pela ambição desmedida, o governo baseado no orgulho e não na razão, dentre outros vários desses argumentos seriam utilizados na descrição dos governos de Cambises e Smérdis, e também estariam presentes nas críticas de Otanes ao governante único. A negatividade se dá, portanto, pela postura do monarca em relação aos seus governados e à própria ascensão e exercício do poder.

Diante dessas possibilidades, aquela que nos parece mais adequada ao nosso estudo é essa última, sobretudo porque ela corresponde, em nossa análise, com o retrato da monarquia apresentado por Heródoto no debate persa. Otanes acusa o governo monárquico de excessos tradicionalmente ligados à visão comum do despotismo, como insolência, inveja, violência sexual, desrespeito aos costumes ancestrais, dentre outros comportamentos considerados amorais ou arbitrários (Hist., III.80). É perceptível notar que, no fragmento, mesmo quando há qualquer tipo de elogio à figura do rei, há também 
uma crítica, como o trecho no qual Megabizo classifica o monarca como insolente, embora tome as decisões com consciência - mesmo que sejam decisões conscientes para atitudes consideradas ruins (Hist., III.81).

Porém, a posição deste terceiro grupo sobre a negatividade das tiranias é controversa. Em seu estudo recente sobre o assunto, Condilo afirma que analisar a questão apenas a partir de aspectos positivos e negativos é simplificar uma discussão mais complexa. Após realizar um estudo sistemático do uso dos termos tirania e tirano nas Histórias ${ }^{40}$, a autora concluiu que são conceitos cujo grau valorativo é muito fluido, sobretudo em um contexto ateniense. O motivo é que nessa pólis o conceito era utilizado por diversos grupos políticos em situações diversas, de modo instrumentalizálo para seu próprio interesse (2010: 126), o que nos leva à questão seguinte. Deste modo, a autora identificou muita ambiguidade na valoração das tiranias por Heródoto, não havendo uma possibilidade de classificar o juízo valorativo como positivo ou negativo numa leitura geral da obra. Ou seja, o uso do termo depende do contexto, do tirano em si e do território no qual o sujeito exerce a tirania.

Para esse estudo, porém, optamos por analisar exclusivamente o juízo valorativo da tirania/monarquia identificado nos antecedentes do debate persa. $\mathrm{O}$ motivo é que as Histórias, conforme já pontuamos anteriormente, só fazem sentido se analisarmos os fragmentos em conjuntos narrativos mais amplos ${ }^{41}$; e, seguindo a conclusão de Meneses Sousa, o debate só pode ser compreendido dentro de seu próprio contexto, ou seja, dentro de um contexto de origem e ascensão de Dario - o que nos leva a pensar inclusive em seus antecessores, que criaram as bases para a chegada do aquemênida ao trono.

Logo, nos parece mais lógico isolar a análise valorativa ao próprio livro III da obra, de modo a compreender como, naquele conjunto de narrações sobre as origens e a ascensão de Dario ao trono, Heródoto demonstra seu pensamento político a respeito do governo monárquico/tirânico. Isso ao mesmo tempo restringe nosso espaço de análise como também aproxima o pensamento político acerca dessa forma de governo ao nosso objeto de estudo.

\footnotetext{
${ }^{40}$ Para demonstrar essa fluidez, a autora contou quantas vezes as palavras tirania e suas derivações aparecem nas Histórias, levando em consideração o contexto e o local (grego ou bárbaro). A conclusão é que o termo é usado por Heródoto em 130 ocasiões, sendo: 75 vezes com sentido neutro, 38 com sentido negativo e 17 com sentido ambíguo.

${ }^{41}$ Conforme os apontamentos de Flory (1997), Darbo-Peschanski (1998) e Hartog (1999).
} 
A partir deste recorte quanto à monarquia/tirania nas Histórias, podemos usar alguns exemplos para seguirmos com nossa análise. Se considerarmos o governo de Cambises como um importante marco inicial para a futura introdução de Dario na narrativa $^{42}$, temos fortes indicativos do pensamento político de Heródoto já a partir do primeiro capítulo do terceiro livro da obra. Conta o historiador que Cambises havia pedido a Âmasis, rei do Egito, a mão de sua filha em casamento. O egípcio, entretanto, enviou ao persa outra mulher. Tratava-se da filha de seu sucessor, Apries. Após descobrir a fraude, Cambises teria marchado contra o Egito tomado de cólera (III.1), num ato de guerra irrefletido. A passagem indica, portanto, que em um ato de fúria o rei persa tomou imediatamente a decisão de levar suas tropas à guerra contra os egípcios, sem refletir sobre as eventuais consequências e sobre os custos de um conflito como esses $^{43}$.

A partir deste ponto, a descrição de Cambises como um mau governante é acentuada pelo historiador em outros fragmentos das Histórias - ressaltando seu pensamento político sobre o governo monárquico. Em diversas outras partes do documento o monarca é tratado como insano e louco. Após vencer os egípcios em combate, por exemplo, Heródoto descreve que

(...) Adentrando o palácio de Âmasis, ele (Cambises) imediatamente ordenou que carregassem o cadáver para fora da câmara mortuária; e quando essa ordem foi cumprida, ele deu a ordem para açoitá-lo, arrancar-lhe os cabelos e perfurálo com aguilhões, e o ultrajou de todas as maneiras possíveis. Quando os executores das ordens estavam cansados de fazer isso (...), Cambises ordenou que o cadáver fosse queimado - uma ordem sacrílega; portanto, nenhuma nação considera correta a ação de queimar os mortos, os persas por considerar o fogo um deus - e não seria correto dar o cadáver de um homem para um deus; por sua vez, os egípcios acreditam que o fogo é uma fera dotada de vida, disposta a devorar todas as coisas que alcança, e que uma vez saciada com repasto morre juntamente com sua presa. (...) Então Cambises mandou fazer algo contrário aos costumes de ambos os povos." (Hist., III.16)

\footnotetext{
${ }^{42}$ Sobretudo se considerarmos que o governo de Cambises termina com a ascensão de Smérdis, supostamente o usurpador que Dario buscou combater para restaurar a dinastia criada no passado por Ciro.

${ }^{43}$ É preciso ponderar que a versão de Heródoto não considera eventuais motivos políticos para a declaração de guerra. O problema do casamento poderia ter sido usado apenas como justificativa para um conflito já planejado anteriormente por Cambises.
} 
O fragmento demonstra que a imagem de Cambises construída por Heródoto é a de um rei que viola o cadáver de um inimigo vencido e, depois disso, fere práticas funerárias tanto do povo adversário como de seu próprio - configurando uma ideia tradicionalmente associada ao governante inescrupuloso e que desrespeita costumes ancestrais - argumentos posteriormente levantados por Otanes em sua crítica à monarquia.

Pouco adiante na narrativa, o historiador volta a esboçar um juízo valorativo do filho de Ciro ao relatar que, após um acesso de fúria, o governante determinou uma marcha contra os etíopes, sem cuidar de nenhum preparativo quanto às provisões da campanha - algo determinante para um conflito militar. Por conta disso, Heródoto afirma que a ordem foi dada por Cambises "como um possesso e como alguém que perdeu o autodomínio" (III.25), e que, pouco depois, ordenou o incêndio de um templo de Zeus.

Porém, a destruição do santuário não seria a única violação religiosa cometida pelo persa. Um exemplo ainda mais marcante, e bastante analisado pelos historiadores, é a execução do touro de Ápis, morto após ser apunhalado pelo próprio Cambises - que também ordenara o assassinato dos sacerdotes egípcios e das pessoas que eventualmente estivessem celebrando a festa dedicada à divindade (III.29).

A imagem do sacrílego Cambises, então, passa a ser constantemente reforçada em pequenos trechos da narrativa, como no parágrafo seguinte, na qual Heródoto afirma que o rei já demonstrava desequilíbrio mental e que enlouqueceu após o ultraje a Ápis (III.30); e quando tentou alvejar Creso, após o lídio dar-lhe o conselho de moderar seus atos para não colocar o trono em risco por seu destempero:

"Senhor, não deixe a juventude e a paixão guiarem seu caminho; imponha um freio a si mesmo e controle-se; prudência é uma boa coisa, e é sábio ser previdente. Mas e quanto a você? Mata homens de teu próprio povo que são culpados de pequenas ofensas; ademais, mata até garotos. Se continuar essas práticas, fique atento que isso vai fazer os persas se revoltarem contra você. A mim, seu pai seriamente ordenou que o aconselhasse e desse sabedoria do que eu considerasse o melhor a ser feito." (Hist., III.36);

Após questionar duramente o conselho de Creso, considerando-o ousado, 
Cambises empunhou seu arco para alvejá-lo com uma flecha, mas Creso saltou e fugiu; Cambises, não podendo alvejá-lo, ordenou seus serviçais de o perseguirem e matarem. Eles, conhecendo o humor de Cambises, esconderam Creso; caso mudasse de ideia, Cambises poderia procurar por Creso, e eles seriam recompensados por terem salvo a sua vida. (Hist., III.36)

As passagens das Histórias, reproduzidas há pouco, demonstram como Heródoto constrói, portanto, a figura de um rei cujo temperamento desmedido vitimou os próprios súditos persas e seus aliados (III.37), tomou decisões impensadas, colocando o próprio exército em risco (III.25) e violou ritos e práticas religiosas - incendiando templos e zombando de imagens sagradas (III.37). Esse Cambises louco (III.38) corresponde ao tipo ideal do tirano-cruel ou do imperador-arrogante (ASHERI, 2006: 31) que nos ajuda a refletir que, ao menos no livro III do documento, o juízo valorativo do historiador indica uma visão bastante negativa da monarquia.

A ascensão de Smérdis, o usurpador, ao trono não nos dá tantos indícios acerca do pensamento político de Heródoto. Entretanto, um fato pode ser usado para sustentar a ideia de que o historiador de Halicarnasso também descreve de forma negativa o governo do mago. Ele é descrito como alguém que chegou ao poder através de uma mentira, algo condenável pela cultura persa, e manipulou os povos de territórios conquistados de modo a evitar revoltas, a partir de uma política que talvez possa ser classificada como populista, usando instrumentos como a dispensa do serviço militar obrigatório e do pagamento de tributos por um período de três anos (III.67). Esta pode ser considerada a personificação do monarca-populista: toma medidas populares que diretamente podem não trazer benefícios ao seu próprio estado, mas que garantem o apoio de parte dos aliados.

Logo, nos parece claro, com esses exemplos, que o juízo valorativo das tiranias no contexto dos antecedentes do debate persa é negativo. Heródoto esboça um pensamento político crítico em relação ao comportamento de Cambises (sobretudo sobre sua hýbris, em diversos momentos, como o desrespeito religioso e às tradições) e mesmo no que diz respeito à chegada ao poder de Smérdis. Deste modo, posteriormente essa visão sobre as tiranias/monarquias terá reflexos importantes nos discursos de Otanes, Megabizo e Dario antes da ascensão do aquemênida - indicando que o debate persa apresenta uma construção de pensamento político que dá continuidade àquilo que já fora prenunciado pelo autor. 
Vamos, agora, analisar o juízo valorativo referente à democracia nas Histórias o modelo político antagônico à tirania/monarquia. 


\subsection{O governo da maioria nas Histórias}

Agora que já discorremos brevemente a respeito da tirania nas Histórias, é preciso pensar nas visões de seu modelo político antagônico: a democracia. Conforme já debatemos, esse antagonismo pode ser compreendido como um elemento discursivo utilizado pelo autor para contrapor a identidade política grega da estrangeira (bárbara), de modo a funcionar como um "dispositivo de rotulagem", conforme argumenta Schneider (2004: 98). Vamos debater a questão no cenário ateniense por se tratar da pólis na qual o modelo democrático helênico surgiu, segundo a tradição mais comumente aceita, e por ser uma comunidade onde o embate entre tirania e democracia parece ter sido especialmente importante no final do século VI a.C. e que deixou uma importante herança para a geração seguinte: a geração de Heródoto e das Guerras Médicas. O autor, por sinal, esteve em Atenas, onde provavelmente leu em público parte (ou partes) de sua obra (WELLS, 1928: 318) durante essa acalorada discussão sobre as constituições e suas implicações para a distribuição de poder.

$\mathrm{Na}$ sessão anterior, usamos os antecedentes do debate persa como exemplo para a análise do pensamento político a respeito da monarquia/tirania nas Histórias, tomando como base, sobretudo, a forma como o historiador construiu a imagem do governo de Cambises - um contexto narrativo fundamental para compreendermos a ascensão de Dario ao trono da Pérsia - evento narrado com algumas semelhanças entre a entronização do aquemênida e a de Deioces, na Média.

Nessa etapa do trabalho, contudo, não será possível empregar o mesmo recorte metodológico, uma vez que a primeira menção do governo popular na obra é justamente o discurso de Otanes em III.80. Logo, não é possível abordar o tema no terceiro livro do documento. Desta forma, optamos por analisar a democracia em Atenas, conforme mencionamos acima, especificamente na transição do governo tirânico para o democrático, no final do século VI a.C. - embora a narrativa sobre esse evento ocorra somente no livro V das Histórias. Essa escolha se dá porque a queda dos pisistrátidas e a nova constituição proposta por Clístenes parece ser o ponto-chave para compreender o antagonismo com a tirania que também está representado no debate persa: ou seja, um conflito ideológico entre um governo supostamente opressor e outro libertador. Em segundo lugar, podemos destacar que essa é uma realidade política muito próxima daquilo que teria influenciado o pensamento político de autores como Heródoto, não 
apenas porque ele esteve em Atenas, mas também porque o embate simboliza a construção identitária que já discutimos anteriormente.

Por fim, o fato de buscarmos um referencial teórico em outro ponto das Histórias não pode ser considerado um problema, uma vez que a divisão de livros, conforme já mencionado no Capítulo 1, é uma elaboração posterior a Heródoto, e porque a ordem de escrita do documento pode não ter sido necessariamente a ordem de publicação ou leitura pública (WATERS, 1996: 17).

Partindo deste princípio, precisamos pensar que a realidade ateniense da segunda metade do século VI a.C. é marcada pela presença de um tirano no poder, Pisístrato, e que o fim desta tirania resultaria, posteriormente, no estabelecimento de uma constituição democrática proposta pelo legislador Clístenes. Deste modo, é um momento crucial para entendermos a relação entre os atenienses e sua nova forma de governo, que se confrontava diretamente com a tirania, além de representar, simbolicamente, a tênue relação conceitual entre os papéis do tirano e do legislador nas cidades-estado.

De forma geral, o século VI a.C. representa um período de convulsão na pólis, resultado dos sucessivos problemas sociais e políticos que atingiam a Atenas no período e que colocavam em choque os vários grupos rivais, como a crise oligárquica oriunda da concentração de terras e da escravidão por dívidas. Legisladores como Sólon tentaram buscar maneiras de amenizar os conflitos, atingindo um certo grau de sucesso. A instauração da tirania foi mais uma etapa deste conturbado período, que opôs ainda mais as facções presentes na cidade. Pisístrato teria chegado ao posto com uma política que podemos classificar como populista, baseada em iniciativas como a distribuição de benefícios e uma marcante preocupação com o respeito às leis estabelecidas. Era uma forma encontrada para legitimar o governo e reduzir a pressão exercida pelos grupos rivais. Tal postura faria com que, no século seguinte, Aristóteles o classificasse como sendo um administrador moderado e que cuidava bem dos negócios públicos (Const. Atenas, 16). Heródoto também afirma que o tirano governou sem mudar as leis e seguindo a constituição vigente (Hist., I.59). Entretanto, a ascensão de Pisístrato ao poder ocorrera por uma via despótica.

É possível compreender essa ideologização a partir das fontes cujas informações foram utilizadas pelo historiador para a composição de sua obra. Parte dos especialistas defende que as fontes de Heródoto sobre a democracia eram, basicamente, atenienses, e 
que provavelmente pertenciam a uma tradição/visão política comumente ligada aos alcmeônidas, uma das famílias aristocráticas de Atenas do período, que rivalizava com o grupo liderado por Pisístrato ${ }^{44}$. Parte da documentação disponível atribui a esse grupo a responsabilidade pela deposição dos seguidores de Pisístrato - seriam, nesse caso, os heróis responsáveis por encerrar o governo opressor, o que criaria as condições necessárias para o surgimento do novo governo popular por Clístenes posteriormente.

Forsdyke ressalta, no entanto, que a versão disseminada pelos alcmeônidas não representava a totalidade das opiniões, mas sim apenas o ponto de vista de uma única família em particular (FORSDYKE, 2001: 330), que certamente tinha interesses privados no ato de disseminar sua versão para a queda de Pisístrato e seus filhos. Essa tradição consideraria que os alcmeônidas seriam os grandes responsáveis pela derrota dos tiranos, pois teriam sido eles que buscaram ajuda em Esparta - que contribuiu para a expulsão de Hípias da Ática. Isso nos daria indícios para pensar que a família em questão teria o interesse de construir uma tradição de que eles contribuíram diretamente para o início e para a consolidação do processo de democratização de Atenas.

Contudo, mais recentemente alguns autores passaram a considerar que não foram essas pessoas, os alcmeônidas, os verdadeiros responsáveis por dar fim ao governo tirânico, mas sim os já mencionados tiranicidas, Harmódio e Aristógiton, os homens que comandaram uma espécie de conspiração para assassinar Hiparco, filho de Pisístrato que sucedera o pai no cargo.

A própria leitura das Histórias resultou em um debate acadêmico sobre essa visão dos alcmeônidas. O motivo é que, na narrativa da queda dos tiranos, o historiador dá pouco destaque às figuras de Aristógiton e Harmódio, os tiranicidas (de quem falaremos mais atentamente logo em seguida), e dedica mais atenção à participação dos alcmeônidas no processo que culminou no fim da tirania. Por conta disso, por muito tempo defendeu-se que as fontes de Heródoto eram, portanto, alcmeônidas (ou ao menos pessoas que reproduziam a tradição ligada à família).

\footnotetext{
${ }^{44}$ Os três grandes grupos rivais de Atenas eram: facção da costa, liderada por Mégacles (membro da família alcmeônida); facção da planície, liderada por Licurgo; e facção das terras altas, liderada por Pisístrato (GOUSCHIN, 1999: 14). A mesma divisão de grupos é narrada por Heródoto em I.59. Segundo Aristóteles, Licurgo era um defensor do regime oligárquico, enquanto Pisístrato advogada em favor do povo (das camadas mais desfavorecidas, como forma de ganhar apoio popular). Por fim, Mégacles seria o defensor de uma espécie de uma política moderada (Const. Atenas, 13). O termo facção, nesse contexto, deve ser compreendido como um grupo político formado por cidadãos que representam ou a maioria ou a minoria dos indivíduos, mas que agem em defesa dos interesses comuns de seus membros. Essa é uma acepção semelhante àquela que seria difundida séculos depois por James Madison, no artigo número 10 de $O$ Federalista, intitulado $O$ tamanho e as diversidades da União como um obstáculo às facções (vide WEFFORT, Francisco. Os clássicos da política - volume 1. São Paulo: Ática 2004, $1^{\text {a }}$ edição).
} 
Rosalind Thomas (1989: 238-282) integra o conjunto de especialistas que nega que Heródoto tenha utilizado sobretudo fontes alcmeônidas para compor a história sobre a transição da tirania para a democracia, e nos dá uma outra interpretação para a construção ideológica do modelo democrático ao sugerir, a partir da interpretação das Histórias, que a narrativa ateniense - sobretudo no que diz respeito à libertação de Pisístrato - é uma composição oriunda de diversas tradições distintas, o que inclui tradições populares e da pólis, ou seja, Heródoto utiliza fontes não-aristocráticas e nãoalcmeônidas no processo de apuração de informações.

Assim, a autora conclui que o historiador de Halicarnasso teve acesso a essa tradição popular por meio de relatos orais, que são carregados de indicativos sobre como os próprios atenienses viam sua história, seus valores de grupo e a instituição de sua democracia no fim do século VI a.C.. Deste modo, as Histórias foram escritas com base em relatos obtidos junto a diversos grupos populares - e, consequentemente, com o uso de fontes diversas - que teriam descrito uma espécie de tipo ideal do regime democrático criado por Clístenes, sempre aplicando uma perspectiva comparativa em relação à tirania de Pisístrato. É a partir deste tipo de elaboração que o ideal da democracia ateniense é construído e narrado pelo autor.

Deste modo, democracia e tirania são formas de governo antagônicas, e esse antagonismo só pode ser compreendido dentro do contexto do próprio século $\mathrm{V}$ a.C. cuja tradição chega a Heródoto apenas no século seguinte. De forma geral, é preciso pensar que a ascensão do governo democrático foi precedida pela necessidade de ruptura com os tiranos, e essa transformação cria as bases ideológicas para a construção da identidade ateniense descrita pelas Histórias - servindo como o dispositivo de rotulagem mencionado por Schneider (2004: 98).

Nesse processo, Heródoto se mostra tributário dos argumentos que abordam uma suposta superioridade da democracia ante a tirania. Forsdyke defende que o verbo katéxein, muito usado pelo historiador, ajuda a compreendermos a construção deste argumento de superioridade (2001: 331-332). De acordo com a autora, o termo é empregado com frequência no contexto ateniense:

"Especificamente, eu defendo que a palavra katéxein era usada pelos atenienses para descrever a sujeição das pessoas por um tirano e era associada às ideias atenienses sobre a fraqueza das sociedades governadas por um tirano em 
contraste com a força das sociedades livres com um sistema político democrático" (FORSDYKE, 2001: 331-332)

Essa teoria cria, portanto, uma dualidade entre aquilo que a autora chama de tirania (ligada à ideia de fraqueza cívica) e a democracia (por sua vez relacionada com uma espécie de resistência cívica contra a dominação e contra a opressão do regime tirânico). Implica dizer que há uma comparação entre as duas realidades, sobretudo no papel do povo nesse processo. Há reflexos deste embate ideológico, inclusive em narrativas não-atenienses, como, por exemplo, no diálogo entre Xerxes e Demarato (Hist., VII.101-105) ${ }^{45}$.

Outro ponto no qual o historiador expressa essa noção de ideologização está ainda no livro I, no conjunto narrativo sobre Creso. Heródoto relata que o lídio buscava alianças com povos gregos durante a guerra contra a Pérsia, e, numa digressão, o historiador conta a história de como Pisístrato chegou à tirania em Atenas. Logo no início dessa digressão, em I.59, o autor diz que o povo ateniense foi mantido em sujeição - novamente o uso do verbo katexein, dando a entender que houve uma fraqueza cívica, e não uma resistência ao poder tirânico. Essa fraqueza fora causada pela própria luta entre os grupos políticos rivais atenienses.

Um terceiro trecho que reforça essa ideia de Forsdyke está em V.91, quando os espartanos afirmam que Atenas, livre dos tiranos, poderia agora se igualar à própria Esparta, tornando-se, portanto, um rival a altura em território helênico. Nesse caso, fica implícito que a democracia gera crescimento e superioridade, enquanto a tirania manteria o Estado em um patamar inferior. A passagem remete ainda à contradição de que os pisistrátidas foram expulsos da Ática com a ajuda dos espartanos - que, por isso, deram condições para o crescimento do poderio ateniense, pois a fundação da democracia fortaleceu a pólis. Logo, nesse contexto, Heródoto utiliza o discurso espartano para reforçar a ideologia referente à democracia de Atenas como sendo superior.

\footnotetext{
${ }^{45}$ O diálogo em questão ocorre durante o início da campanha de Xerxes contra a Hélade. Na passagem, Heródoto narra que o persa convocou Demarato à sua presença para questioná-lo a respeito dos povos gregos. Xerxes indaga o espartano sobre a capacidade dos helenos em resistir às forças militares persas (VII.101). A resposta de Demarato foi que os helenos estavam acostumados a enfrentar com coragem a pobreza e o despotismo, e que, por isso, eles não aceitariam a servidão imposta pela Pérsia e combateriam mesmo em situações completamente adversas (VII.102). O diálogo expõe, de certa forma, a dualidade entre a resistência cívica das cidades-estado gregas perante a tirania e a escravidão impostas pela Pérsia que só lograria êxito caso houvesse uma fraqueza cívica de não resistir à invasão estrangeira. É, portanto, um choque ideológico entre práticas democráticas e autocráticas, a partir de uma perspectiva helenocêntrica.
} 
"Eu sugeri que os espartanos enunciam a ideologia democrática ateniense como uma ligação entre democracia e resistência cívica contra a tirania e a fraqueza cívica. A importância deste conjunto de associações em ideologia democrática ateniense pode ser confirmada por ser com o retorno à análise das passagens atenienses, nas quais há a mesma conexão entre o verbo katêxein, tirania e fraqueza cívica. Essas passagens mostram que essas associações ideológicas eram correntes em Atenas muito antes de Heródoto ter composto suas Histórias e, portanto, não são apenas opiniões pessoais do historiador sobre os méritos de um regime democrático" (FORSDYKE, 2001: 336)

Essa afirmação reforça o argumento de que Heródoto pode ter sido influenciado pelas fontes populares, que disseminavam a tradição de que democracias são formas de governo superiores em comparação às tiranias. $\mathrm{O}$ autor de Halicarnasso não é o único que bebe nessa tradição. Tucídides também é tributário da opinião quando afirma, em I.17, que os tiranos são usurpadores do povo em cidades helênicas, e que por toda parte a Hélade teria sido impedida de realizar feitos notáveis por causa das tiranias. E, ao afirmar isso, o historiador também usou o mesmo verbo mencionado por Forsdyke ${ }^{46}$. Essa ideia pode ser aplicada não apenas ao tirano ateniense, mas de forma geral também se encaixa em um padrão de análise que remete às monarquias Orientais, de um modo mais amplo.

\footnotetext{
${ }^{46}$ A autora afirma que outros textos gregos do período também utilizam a mesma dualidade entre tirania/democracia, como Ésquilo, Xenofonte e Eurípedes. No primeiro caso, a peça Os Persas apresenta um paralelo com Heródoto na cena em que Atossa é atormentada por sonhos de Xerxes invadindo a Grécia. O sonho retrata o fracasso de Xerxes ante uma Atenas democrática, indicando um contraste ideológico entre democracia e tirania. Haveria, ainda, um contraponto entre a servidão oriental e a liberdade grega. O fragmento, segundo Forsdyke, lembra os espartanos em Heródoto V.91. No caso de Eurípedes, o paralelismo com as Histórias está na peça Suplicantes. A associação entre democracia e tirania está expressa na crítica contra o governo democrático feita por um nobre tebano: segundo ele, os homens comuns seriam incapazes de governar com sabedoria, e que a maior parte das pessoas de baixa hierarquia ganhariam reputação constrangendo o povo com sua língua. Esse nobre em Eurípedes sugere, com o uso da palavra katéxeiv, que a democracia poderia se transformar em uma tirania se os homens se tornassem demagogos. Forsdyke afirma que há, portanto, uma associação entre tirania e fraqueza cívica, de um lado, e democracia e força cívica, de outro - remetendo à ideologia ateniense. Por fim, Xenofonte expressa o choque entre os dois modelos políticos, a partir de uma ideologização da democracia, ao descrever o cavalo mantido nas rédeas no tratado Sobre a equitação: algo similar à construção textual herodotiana, de que a tirania mantinha o povo ateniense sob suas mãos. Para mais detalhes sobre essas associações entre tirania e democracia, que partem de uma tradição também presente nas Histórias, consultar FORSDYKE, Sara. Athenian democratic ideology and Herodotus' Histories, in American Journal of Philology, vol. 122, n. 3, 2011, p. 336-341.
} 
Nesta etapa, como já discutimos brevemente a construção da ideologia democrática ateniense por Heródoto, é interessante voltarmos a pensar no assassinato de Hiparco, filho de Pisístrato, como um importante marco simbólico de resistência cívica à tirania. A própria narrativa do evento e o seu desfecho nos leva, ainda no livro $\mathrm{V}$ das Histórias, a analisar como o historiador reforça a classificação ideológica da superioridade democrática ante a tirania.

A polêmica envolvendo os tiranicidas reside no fato de que a documentação disponível a respeito deles é parcialmente controversa. Alguns elementos são divergentes, sobretudo no que diz respeito à importância da dupla no processo de deposição do regime autocrático. Três fontes gregas distintas, que datam de períodos diferentes, registram a história de Harmódio e Aristógiton com sensíveis divergências: o próprio Heródoto, nas Histórias; Tucídides, na História da Guerra do Peloponeso; e Aristóteles, na Constituição de Atenas. Cada um dos três apresenta a história com pesos diferentes para a participação dos tiranicidas.

Embora existam diferenças nas três versões, podemos constatar que Heródoto parece reproduzir ao menos uma parte de uma importante tradição política que marcou aquela geração e que guarda a herança dos tiranicidas e da transição entre tirania e democracia. A morte dos tiranos compreende uma das principais estórias da tradição democrática ateniense - da qual Heródoto parece ser tributário, por meio dos relatos orais que colheu para escrever sua obra. Esse seria um grande elemento da construção ideológica ateniense acerca do governo popular e da resistência ao poder autoritário e despótico de Pisístrato, de seus filhos e de seus seguidores. De uma forma geral, o episódio mostra a ocasião em que dois indivíduos, duas pessoas comuns, deram um importante passo para a derrota dos tiranos.

Essa estória de libertação, portanto, integra um conjunto de elementos que, juntos, contribuíram para a formação da identidade ateniense da era democrática. É justamente por isso que o evento dos tiranicidas ajuda a solidificar a ideia de que a pólis em questão era uma comunidade política superior aos Estados bárbaros, que desconheciam instituições de descentralização do $\operatorname{poder}^{47}$.

\footnotetext{
${ }^{47}$ Essa ideia sugere que o debate persa indica que Heródoto não tinha clareza quanto à concepção de regime político persa, que era altamente burocratizado, hierarquizado (THOMPSON, 1996: 53) e até certo ponto descentralizado, se considerarmos a autonomia dada aos governantes das satrapias (ASHERI, 2006: 46-47).
} 
Entretanto, o historiador de Halicarnasso é muito sucinto ao descrever o papel de Harmódio e Aristógiton na queda dos tiranos em Atenas. Conforme já mencionamos, o documento parece dar mais ênfase à participação dos alcmeônidas. A exemplo do que ocorre com outros personagens na narrativa, como Dario ${ }^{48}$, os tiranicidas são introduzidos nas Histórias de forma repentina e inesperada, sem muitas apresentações ou sem que o autor tenha apresentado a dupla de forma mais detalhada. Heródoto apenas explica que Hiparco foi morto pelos dois, numa afirmação abrupta. Porém, apesar da descrição sintética e inesperada na obra, o evento em si deixa efeitos importantes que nos indicam o pensamento político herodotiano acerca da transformação política na pólis a partir da substituição do governo tirânico pelo democrático.

O relato desta estória começa no capítulo 55 do livro $\mathrm{V}$, que narra a chegada de Aristágoras, de Mileto, a Atenas. Vindo da costa da Ásia Menor, ele havia pedido inicialmente apoio dos espartanos para a causa jônica, que se rebelava contra a dominação persa na região - o que levou as cidades a se revoltarem em busca de libertação do domínio e da influência de estrangeiros. O pedido de auxílio foi negado em Esparta e, por isso, Aristágoras decidiu buscar ajuda junto aos atenienses. O fragmento é emblemático porque, numa de suas digressões acerca da opressão política, Heródoto começa a descrever como Atenas se livrou de seus tiranos - situação que poderia ser repetida em Mileto. É essa parte que mais nos interessa.

Segundo a narrativa, Pisístrato tinha dois filhos: Hiparco e Hípias. O primeiro sucedera o pai e foi alvo de uma conspiração dos tiranicidas, Harmódio e Aristógiton. O capítulo é apresentado como um evento de conotação política, porém, a versão de Aristóteles contrasta com a de Heródoto e indica que, na verdade, se tratava de uma intriga amorosa. Heródoto conta que a dupla se dizia descendente de fenícios, acolhidos inicialmente pelos eritreus e depois pelos atenienses, sem, no entanto, dispor de todos os benefícios dos demais cidadãos (V.55). Provavelmente eram considerados metecos. Os dois teriam emboscado Hiparco durante as festividades das Panatenáicas, colocando fim ao regime tirânico.

\footnotetext{
${ }^{48}$ Dario surge na história da conspiração dos sete, no livro III, de forma repentina. Conta Heródoto que, após a reunião dos seis outros conspiradores, Dario chegou a Susa e se uniu ao grupo. "A narrativa herodotiana não nos dá nenhuma explicação para o fato de Dario ter vindo de Susa com a intenção de conspirar contra a vida do Mago; Heródoto introduz a chegada de Dario com um simples 'ele chegou' (70.3) e não adianta nada sobre a sugestão de um plano ou missão.” (MENESES SOUSA, 2010: 43).
} 
Entretanto, o regime tirânico não foi dissolvido. Hípias continuava no cargo. Os alcmeônidas, exilados de Atenas e, portanto, rivais de longa data dos pisistrátidas (V.62), teriam sido os principais protagonistas da transformação política da cidade. Eles viviam em exílio e usaram de sua influência e recursos para subornar a sacerdotisa de Delfos para que ela sempre aconselhasse os espartanos a libertar Atenas, quando estes fossem ao santuário pedir qualquer tipo de orientação (V.63). O plano deu certo, segundo Heródoto, e os espartanos enviaram uma primeira delegação militar para combater o filho de Pisístrato. No entanto, a investida deu errado.

Em seguida, Esparta designou o rei Cleomenes para comandar uma nova campanha, que é narrada nos capítulos 64 e 65. Desta vez a batalha foi vencida pelos espartanos, que em seguida e marcharam sitiaram Hípias e seus seguidores na acrópole. Contudo, o desfecho da história é a captura do filho do tirano, que, como resgate, precisou aceitar sua saída da pólis - exigência que foi cumprida. Assim, o historiador descreve como, em sua versão, os alcmeônidas usaram a astúcia para obter o apoio dos espartanos para depor os tiranos. É esse tipo de argumento que serve como base para justificar a possível predileção alcmeônida do autor, em detrimento de Harmódio e Aristógiton. De qualquer forma, é uma estória ateniense ideologizada sobre a superação da tirania.

Heródoto foi sucinto ao reproduzir a tradição dos tiranicidas. Tucídides nos fornece mais detalhes sobre a participação da dupla, mas em linhas gerais também relega um papel de maior destaque aos alcmeônidas e aos espartanos nesse processo. A narrativa tucidideana do episódio está presente no livro VI da História da Guerra do Peloponeso, também em uma digressão. De acordo com o autor, os verdadeiros responsáveis pela queda dos tiranos foram os guerreiros de Esparta, que vieram em auxílio aos alcmeônidas - e não Harmódio e Aristógiton (VI.53), que contribuíram apenas na medida em que executaram Hiparco. O regime, porém, permaneceu em vigor. Os lacedemônios, esses sim, teriam sido responsáveis pelo restante do processo de transição política que culminaria nas reformas constitucionais de Clístenes.

A histórica participação dos tiranicidas, entretanto, ganha um papel mais pessoal do que político na narrativa de Tucídides: Harmódio seria amante de Aristógiton; Hiparco, filho de Pisístrato, teria tentado seduzir Harmódio, que rejeitou o tirano e contou a Aristógiton. Hiparco, porém, sentindo-se rejeitado, humilhou publicamente a dupla (VI.54), que se vingou durante as comemorações das Panatenáicas (VI.57). 
Imediatamente após a execução do tirano, Harmódio foi morto pelos guardas de Hiparco, e Aristógiton capturado.

Essa versão é semelhante, em alguns aspectos, à narrada por Aristóteles em $A$ constituição de Atenas. Na obra, o filósofo, que escreveu no século seguinte a Heródoto e Tucídides, relembra do episódio com mais detalhes, retomando, inclusive, os eventos que levaram Pisístrato ao poder, como resultado das lutas entre facções na pólis - ou seja, o problema nasce a partir de uma crise oligárquica/aristocrática.

Segundo o filósofo, dos filhos do tirano, Hípias era o mais velho, além de ser político por natureza. Hiparco, por sua vez, era mais inclinado às diversões cotidianas, e pouco se interessava por política. O terceiro filho, Tétalo, teria se apaixonado por Harmódio, que não correspondeu. Tétalo, então, o ofendeu em público. Como vingança, Harmódio e Aristógiton organizaram um plano e assassinaram Hiparco nas Panatenáicas. Nesse ponto, a narrativa aristotélica coincide com a de Tucídides: Harmódio foi executado, enquanto Aristógiton foi capturado, torturado e condenado por Hípias, pouco depois.

Essa questão é importante porque, relata Aristóteles, Hípias apertou o cerco contra supostos conspiradores, tornando o regime tirânico mais violento - o que teria levado alguns grupos, como os alcmeônidas, a buscar apoio contra o filho de Pisístrato, o que culminaria na dissolução da tirania e no estabelecimento da democracia.

Logo, temos versões semelhantes em sua essência, mas com sutis diferenças em seu detalhamento. Independentemente dessas diferentes visões acerca do episódio, é importante pensarmos que a transição da tirania para a democracia fora difícil e conquistada por meio da luta e da resistência ao governo tirânico. É mais um elemento retórico de ideologização.

Retomando as Histórias, a narrativa a respeito dos tiranicidas retrata um importante momento de transformação em Atenas, simbolizando mais uma etapa das mudanças na forma de governo da pólis. E embora o historiador tenha dado pouco destaque à passagem do assassinato de Hiparco, o nome de Aristógiton e Harmódio volta a ser mencionado pelo autor no livro seguinte, como uma maneira de enaltecer a luta contra a opressão - que seria uma vitória da resistência cívica democrática ante a fraqueza cívica tirânica (conforme a terminologia empregada por Forsdyke).

O nome da dupla é mencionado quando o general Milcíades discursava para Calímaco, polemarco ateniense, às vésperas da Batalha de Maratona - tão celebrada em 
Atenas como um momento histórico de vitória da liberdade democrática ante o despotismo persa - na visão helênica. O general tentava convencer Calímaco a atacar os persas antes mesmo da chegada dos reforços prometidos por Esparta, para pegá-los desprevenidos e, assim, conquistar uma importante vitória para assegurar a liberdade das cidades-estado. Segundo o historiador, essas foram as palavras usadas por Milcíades no famoso pronunciamento:

\begin{abstract}
"Calímaco", ele disse, "a escolha hoje é sua, se você vai permitir que Atenas seja escravizada, ou assegurar a sua liberdade, e assim deixar tal memória para toda a posteridade, como nem mesmo Harmódio e Aristógiton deixaram. Por enquanto Atenas está na maior situação de perigo desde que se tornou a cidade mais importante; e se o povo se curvar para os medos, seu destino é certo, pois serão entregues a Hípias." (HERÓDOTO, Hist., VI.109).
\end{abstract}

O assassinato de Hiparco e, posteriormente, a expulsão de Hípias de Atenas, colocou fim a mais de três décadas de tirania, que perdurou de 545 a.C. a 509 a.C., com um pequeno intervalo ocasionado pelo breve exílio de Pisístrato, conforme relatado em I.60. A partir disso, o historiador passa a reforçar em diversos fragmentos do documento que a substituição do governo tirânico foi positiva para os atenienses - o que, consequentemente, expõe um caráter eminentemente negativo associado ao governante único (V.65). No capítulo seguinte o autor nos dá um dos maiores indicativos acerca de seu pensamento político no que diz respeito a essas duas formas de governo, comparando-as diretamente no documento:

Atenas, que antes já era grande, cresceu ainda mais agora quando se livrou de seus tiranos; e havia dois homens que ocupavam a liderança, Clístenes, um alcmeônida (...) e Iságoras, filho de Teisandro, um homem de uma nobre família, mas cuja linhagem não posso esclarecer. (HERÓDOTO, Hist., V.66)

O trecho é significativo porque o historiador faz uma comparação direta entre os dois modelos constitucionais, indicando que Atenas cresceu em importância após o fim da tirania. Ou seja, o autor implicitamente constrói um juízo valorativo entre as duas formas de governo, classificando uma como mais adequada do que a outra: a democracia, libertadora, ante a tirania. Esse pensamento é reforçado pouco adiante na 
narrativa, após relatar a respeito das reformas sociais e políticas propostas posteriormente por Clístenes.

Assim cresceu o poder dos atenienses; e isso é comprovado não por um caso isolado, mas sim pela maioria das circunstâncias em que a igualdade se mostrou uma boa instituição; olhando para eles enquanto eram governados por tiranos, os atenienses não eram melhores na guerra do que qualquer um de seus vizinhos, mas uma vez que se livraram dos tiranos eles assumiram de longe o primeiro lugar. Isso, então, prova que enquanto eram oprimidos eles se mostravam propositalmente covardes, como homens servindo a um senhor, mas quando eles se tornavam livres cada um passou a zelar para alcançar seu próprio benefício. (HERÓDOTO, Hist., V.78)

O fragmento evidencia que o historiador expõe uma significativa classificação a respeito da tirania e da democracia, caracterizando-as, respectivamente, como governos centralizador e emancipador, e pelos quais as pessoas viveriam sob uma espécie de reclusão política, no primeiro caso, e atuação coletiva, no segundo. Heródoto, ainda, frisa que a igualdade (ou a isonomia, conforme veremos na argumentação utilizada por Otanes), possibilita uma superioridade ao Estado.

Importa que Heródoto, na verdade, está reproduzindo no documento uma história bastante importante para os atenienses, provavelmente algo muito discutido publicamente. Os tiranicidas foram honrados com um monumento, em homenagem a seu feito que pôs fim à tirania, além de figurarem nos documentos de Aristóteles e Tucídides, além do próprio Heródoto.

O autor de Halicarnasso, portanto, é tributário de uma tradição que expõe as vantagens da democracia ante a tirania, o que representa a reprodução de uma ideologia de superioridade. Logo, há um juízo valorativo positivo acerca do governo democrático neste contexto. O modelo antagônico, descrito na sessão anterior deste capítulo, é visto por Heródoto como um governo negativo, opressivo e repleto de hýbris por parte do governante. Esse pensamento a respeito da democracia e da tirania acabará se desdobrando posteriormente, no debate persa. 


\subsection{O governo de poucos nas Histórias}

Nas duas sessões anteriores deste capítulo, trabalhamos a visão de Heródoto acerca da tirania nas Histórias (especificamente nos antecedentes do próprio debate persa) e da democracia (num contexto ateniense de transição entre a tirania dos pisistrátidas e a criação de uma ideologia política referente ao governo popular). São dois contextos distintos, porém, conectados na medida em que há a elaboração de um pensamento político antagônico entre essas duas formas de governo, comparando a liberdade do modelo político grego com a autocracia atribuída aos bárbaros. Esse é, em nossa opinião, o reflexo de uma elaboração teórica por parte do historiador, pela qual discute as diferenças entre as constituições e suas implicações para a distribuição/concentração de poder. O diálogo entre os modelos reside justamente na concepção herodotiana conflitante entre governos tirânico e democrático.

Tomando como correta a premissa de que há um embate ideológico entre essas duas formas de governo na obra herodotiana, é preciso reconhecer que existe um protagonismo entre Otanes e Dario no debate persa, respectivamente os defensores da democracia e da monarquia. Contudo, não podemos ignorar a presença de Megabizo na discussão e a sua proposta de instaurar o regime oligárquico na Pérsia. O governo de poucos pode ocupar uma posição hierarquicamente inferior em relação às outras duas formas de governo no fragmento III.80-82, porém, deve ser avaliado como uma espécie de meio termo entre a concentração e a distribuição de poder, oferecendo a oportunidade de ampliar a representatividade no governo, evitando assim a concentração, no entanto, sem permitir a criação de um governo das massas.

Logo, se a oligarquia foi inserida no debate persa, ela possui uma importância significativa no pensamento político herodotiano acerca das constituições. Portanto, nos cabe avaliar brevemente como a ideia sobre essa forma de governo é trabalhada por Heródoto. Para tanto, podemos recorrer a uma metodologia que mescle duas perspectivas distintas: a análise do contexto ateniense (no qual as facções desempenharam um papel fundamental para a ascensão de Pisístrato e também para a queda dos tiranos) e dos antecedentes do debate persa (que apresenta elementos de choque entre os nobres conspiradores que se insurgiram contra Smérdis) ${ }^{49}$.

\footnotetext{
${ }^{49}$ Essa metodologia é apropriada inclusive se considerarmos que a oligarquia/aristocracia é apresentada como um meio termo entre as duas constituições antagônicas do debate persa. Logo, se ela é um modelo intermediário entre a concentração e a distribuição, é válido analisá-la tanto em um contexto persa
} 
Antes de partirmos para a análise desses casos, é importante, primeiramente, indicar que também há uma ambiguidade entre os conceitos de oligarquia e aristocracia nas Histórias. A exemplo do que ocorre com a monarquia e com a tirania, os termos oligarquia e aristocracia são fluidos e intercambiáveis, e em diversas passagens o historiador os utiliza como sinônimos. Os dois acabam servindo para indicar uma forma de governo pela qual um grupo limitado de indivíduos ocupa os cargos de comando. Logo, não há um juízo valorativo claro indicando as diferenças entre o governo de poucos voltado para o bem comum daquele destinado à busca de benefícios para os próprios membros do grupo. Essa distinção surgiria apenas posteriormente na classificação de alguns filósofos políticos, como, por exemplo, na teoria aristotélica das formas de governo apresentada pelo autor no terceiro livro da Política.

Essa ausência de distinção é refletida inclusive no debate persa. O discurso de Megabizo, conforme veremos detalhadamente no próximo capítulo, pode ser interpretado de forma dúbia, indicando que o nobre defendia, na realidade, a adoção de uma constituição aristocrática (MYERS, 1991: 545), por conta dos valores dos membros do quadro político apresentados em sua argumentação (como o fato de os melhores persas tomarem conta da administração do Estado), enquanto Heródoto, como narrador, apresenta a constituição proposta como sendo oligárquica (Hist., III.81).

Independentemente de considerarmos a proposta de Megabizo aristocrática ou oligárquica, o modelo constitucional defendido permitiria que um pequeno grupo de persas formasse o corpo político do Estado. Dentre eles, estariam os sete conspiradores que lutaram contra Smérdis: Dario, Otanes, Aspatines, Góbrias, Intafernes e Hidarnes, além do próprio Megabizo. O motivo é que eles seriam mais capacitados para desempenhar a função: espera-se que dos melhores homens emanem as melhores decisões (Hist., III.81). Seriam, portanto, nobres que integrariam uma elite política persa - que formaria o novo quadro político caso a proposta de Megabizo tivesse saído vencedora.

Isso nos leva a pensar na luta política entre grupos tanto dentro quanto fora da Pérsia. Primeiramente, vamos fazer uma breve reflexão acerca da aristocracia no contexto da transição entre a tirania e a democracia em Atenas, para depois compreendermos as cisões dos grupos persas.

(classificado genericamente por Heródoto como tirânico) e ateniense (ideologicamente tipificado como democrático), ou seja, os dois pólos do embate ideológico. 
Já antecipamos a ideia de que a oligarquia/aristocracia pode ser interpretada como um governo intermediário entre a monarquia e a democracia. Analisando a realidade política ateniense, percebemos que, de certa forma, esse modelo também se reproduz nas Histórias no conjunto narrativo que envolve a ascensão de Pisístrato e, posteriormente, na queda do tirano. As lutas aristocráticas da pólis permeiam não apenas a discussão entre concentração e distribuição de poder, mas também como os grupos declaram apoio ora em favor do tirano, ora em favor de sua derrubada.

O surgimento da política de grupos de nobres em Atenas, porém, é anterior ao século VI a.C. Segundo Mossé (1970: 18), a antiga monarquia ateniense fora substituída por um tipo de governo aristocrático, cujas atribuições estavam distribuídas em três autoridades básicas. Por um lado, havia o basileus, que basicamente resguardava atribuições de caráter religioso. Por outro, havia o polemarco, que herdara dos antigos reis as funções como chefe militar. Por fim, havia o arconte, que se ocupara da tarefa de administrador da justiça. Enquanto instituição política de governo, essa aristocracia era completada por

seis tesmótetas encarregados da redação das leis e um secretário, para formarem um colégio de dez magistrados postos à cabeça da cidade e usando todos o nome genérico de arcontes. Os arcontes administravam a cidade assistidos pelo conselho formado pelos antigos arcontes e chamado Conselho do Areópago, do nome da colina dedicada ao deus Ares, onde se reunia. (MOSSÉ, 1970: 18)

Essa sociedade aristocrática tinha suas bases, sobretudo, na concentração de riquezas e na posse de terras. Isso resultava, segundo Hirata, em uma espécie de monopólio de todas as esferas de justiça por meio do controle das magistraturas (HIRATA, 1996/1997: 65). Contudo, a legitimidade desses grupos no poder também estava fundamentada por motivos religiosos, uma vez que

A hegemonia política da aristocracia fundiária contava com o respaldo fundamental da religião. Esta era a base ideológica de todo o sistema. As grandes famílias detentoras do poder reportavam-se a antepassados heróicos, cuja memória era alimentada pelos cultos de cunho privado, mas que assumiam uma dimensão pública na medida em que tal ascendência ilustre justificava a posse de um sacerdócio de importantes divindades políades. (HIRATA, 1996/1997: 65) 
Isso implica dizer, portanto, que a concentração de terra e de riqueza, além do monopólio dos cargos público-administrativos, era assegurada pela legitimação oriunda dos elementos religiosos de Atenas. Esses aristocratas, deste modo, comandaram a pólis a partir de práticas de grupo. Esse tipo de governo de poucos mantém seus efeitos posteriormente, chegando a influenciar a política de Atenas no século VI a.C., mesmo com a presença de um tirano no cargo. Isso ocorre porque os grupos mantinham sua influência na medida em que declaravam apoio ao governante - ou se reuniam a outras elites para combatê-lo.

O fato é que esses grupos tinham interesses distintos na cidade, e travavam um acirrado conflito entre si na busca pela expansão de sua influência e de seu prestígio. Heródoto aponta a presença de três grupos muito bem identificados no século VI a.C., que basicamente poderiam ser divididos a partir de sua posição geográfica em Atenas. Eram, portanto, elites territoriais, que construíam sua base de apoio principalmente na localidade onde viviam.

A história da aristocracia/oligarquia ateniense é narrada nas Histórias em uma digressão dentro do lógos de Creso. De acordo com o historiador, havia uma desavença histórica entre os moradores da costa e os da planície, no século VI a.C.. Esses grupos, diante do impasse, se organizaram em duas facções distintas. Mégacles, da família dos alcmeônidas, liderava os atenienses da costa, enquanto seu rival era Licurgo, que chefiava os indivíduos da praia. Pouco depois disso, Pisístrato, descrito por Heródoto como alguém que almejava o poder soberano, organizou uma terceira facção ao reunir os habitantes das montanhas (Hist., I.59), formando assim o terceiro partido geográfico da cidade.

A versão das Histórias é muito semelhante à da Constituição de Atenas, na qual Aristóteles argumenta que os grupos seguiam ideologias políticas bem demarcadas num período de tumultos internos causados por motivos diversos, mas atribuídos às reformas de Sólon no início do século. Um dos problemas é que o legislador aboliu a escravidão por dívidas. Como a concentração de riquezas era a base para o poder dos grupos, muitas pessoas foram à pobreza por conta da nova lei. Segundo Aristóteles, Mégacles e seus aliados eram favoráveis à política moderada; Licurgo era um oligarca; por fim, Pisístrato podia ser classificado como um líder que parecia ser mais democrático por se sustentar no apoio das massas (ARISTÓTELES, Const. Atenas, 13). Esse terceiro grupo teria ganhado muitos adeptos advindos da política de cancelamento de dívidas que 
Sólon aprovara anteriormente - nobres que viram a riqueza minguar quando se aboliu a escravidão por dívidas. O empobrecimento levou essas pessoas a aderirem à facção de Pisístrato, tornando-o mais popular. Além disso, essa situação criou condições para que ele de fato conquistasse a tirania posteriormente. Além disso, tanto Aristóteles quanto Heródoto atribuem parte do apelo popular de Pisístrato ao fato dele ter atuado como general na guerra contra Mégara - possivelmente como polemarco, um cargo de distinção.

Pode-se dizer, portanto, que o conflito aristocrático criou as condições para que um tirano ascendesse ao poder em Atenas, colocando-se como o indivíduo capaz de levar ordem ao caos.

A versão aristotélica nos indica que esse foi um choque entre ideologias distintas, uma vez que cada grupo lutava para fazer com que seus interesses prevalecessem. Logo, as elites estavam preocupadas em suplantar os interesses das facções rivais, e não encontrar um modo de levar benefícios a toda a comunidade política.

Heródoto, ainda em I.59, narra que Pisístrato conquistou o poder valendo-se da popularidade, do oportunismo e da astúcia. O líder da montanha feriu a si próprio, mas alegou ser vítima de um ataque inimigo. Por conta de seu prestígio, ele conseguiu convencer a população de que precisava andar armado para se proteger de novas agressões dos rivais. Com a aprovação do direito de andar com uma escolta armada, Pisístrato ocupou a acrópole e chegou à tirania. Essa ascensão ocorrera em meio a uma grave crise interna. A idéia de que a legislação se mostrava incapaz de conter os problemas sociais, logo, Pisístrato surgiu como uma alternativa para a solução dos conflitos.

Essa hipótese nos mostra que a luta interna entre os grupos aristocráticos/oligárquicos tem, nas Histórias, a função de justificar um caos político e social nas póleis. E apenas a ascensão de um indivíduo dotado de astúcia é capaz de resolver o problema, reordenando a sociedade. Posteriormente, Heródoto usaria uma fórmula semelhante para idealizar as figuras de Deioces e Dario a partir de uma perspectiva muito parecida: os dois são retratados como governantes que também emergiram em um momento de caos, usaram a sua métis para superar as disputas entre as elites, levaram ordem ao Estado e, com isso, conseguiram se transformar em governantes únicos. 
Entretanto, a história de Pisístrato revela que nem mesmo o advento do tirano livra as cidades dos aristocratas/oligarcas. A influência das elites não terminou com o surgimento do governante único. Segundo Heródoto, diante da ascensão de Pisístrato seus antigos rivais, Mégacles e Licurgo, decidiram deixar as diferenças de lado e unir forças contra o tirano (Hist., I.60). Essa aliança culminou no primeiro exílio de Pisístrato, que ocorreu seis anos após sua chegada ao poder, de acordo com narração de Aristóteles (Const. Atenas, 14).

O historiador de Halicarnasso não detalha como ficou a situação política ateniense nesse período, mas afirma que logo após a deposição do inimigo os outros dois grupos voltaram a conflitar entre si, retomando a situação de caos imposta pela cisão entre os grupos da costa e da planície. Aristóteles argumenta que Mégacles, chefe dos alcmeônidas, sofria muitas pressões por conta dessa dissensão política, e buscou apoio no próprio Pisístrato para vencer seu rival. Nesse ponto, as versões de Heródoto e Aristóteles são semelhantes: Mégacles ofereceu sua filha em casamento para Pisístrato, como forma de estabelecer uma ligação, e juntos articularam um plano para o retorno do tirano a Atenas, que contou com a aprovação popular. Ou seja, um aristocrata até então rival e que conspirara contra Pisístrato o ajudou em seu regresso.

Esse retorno, porém, durou sete anos (Const. Atenas, 14), pois Pisístrato teria se desentendido novamente com Mégacles, foi expulso mais uma vez da cidade; em seguida, empreendeu uma série de conquistas militares fora do território da Ática para reunir forças, até que, finalmente, tomou Atenas mais uma vez, desarmou a população e restabeleceu a tirania ${ }^{50}$.

Essa situação mostra como a política ateniense sofria a influência das decisões dos grupos aristocráticos/oligárquicos da cidade. Essas facções uniam-se em alianças frágeis, que frequentemente eram desfeitas por razões políticas (quase nunca com o objetivo de beneficiar a comunidade política), modificando o curso das próprias lutas internas. Essa situação expressa o caos interno e a necessidade de superar os problemas causados pelas elites. Deste modo, a oligarquia influencia diretamente na alternância entre as situações de caos e ordem nas Histórias - situação que precisa ser superada. Logo, Heródoto nos indica a ideia de que o governo de poucos não é capaz de produzir ordenamento social e político.

\footnotetext{
${ }^{50}$ Os relatos de Heródoto e Aristóteles são muito semelhantes no que diz respeito às idas e vindas de Pisístrato ao posto de tirano. É plausível supor que Aristóteles usou a narrativa herodotiana como base para a sua versão da história.
} 
A elaboração desse pensamento acerca da aristocracia/oligarquia também pode ser compreendida a partir da leitura dos antecedentes do debate persa, no próprio livro III das Histórias, portanto, uma narrativa dentro de um contexto oriental. A ascensão de Smérdis ao trono e a posterior luta travada para a queda do tirano podem ser interpretadas como parte da influência das elites dentro do império persa. Embora não houvesse uma constituição aristocrática na Pérsia, podemos considerar que os nobres se dividiam em grupos com posições políticas privilegiadas e divergentes, dispondo de maior ou menor grau de prestígio junto ao monarca. Além disso, devemos reconhecer que em muitas situações essas diferenças entre os membros das elites culminaram em conflitos ideológicos pautados pelos interesses particulares de cada grupo.

A própria conspiração dos sete é um exemplo do embate entre nobres da elite que se encontravam em lados distintos do jogo político. Logo após a inclusão de Dario ao grupo, o aquemênida passou a confrontar o posicionamento de Otanes, mostrando que havia uma rivalidade entre os dois. Se analisarmos essa rivalidade a partir das categorias expressas no debate persa, podemos dizer que é um confronto entre os partidários da monarquia e da democracia, respectivamente. Portanto, é uma dissensão entre dois nobres com ideias divergentes acerca da melhor forma de governo.

O primeiro choque entre eles é narrado em III.71, quando Dario defende a ação imediata contra Smérdis, pois seria a melhor alternativa para assassinar o mago antes que ele recebesse qualquer alerta sobre a conspiração. Otanes, por sua vez, responde ao aquemênida, inicialmente elogiando o valor de Dario para a Pérsia, mas logo em seguida o aconselha a ser mais prudente antes de advogar em favor do ataque. Dario, porém, é mais incisivo ao contra-argumentar o rival:

"Senhores, se vocês fizerem como Otanes aconselha, devem saber que vão perecer de uma maneira miserável; alguém informará tudo ao mago, desejando recompensas pessoais. Agora, teria sido melhor para vocês se tivessem realizado seus objetivos por vocês mesmos; mas vendo que era seu intento ampliar a trama para mais pessoas, e por isso confiaram em mim para participar dela, vamos, eu digo, agir hoje mesmo; se deixarem passar o dia de hoje, eu asseguro que ninguém vai acusá-los antes de mim, porque eu mesmo vou relatar a questão para o mago.” (HERÓDOTO, Hist., III.71) 
Podemos considerar que a posição oposta entre os dois não é reflexo de uma preocupação individual de cada um, mas sim uma preocupação ligada aos grupos aos quais estavam integrados - sobretudo se pensarmos que dificilmente os sete agiram sozinhos contra Smérdis, e que provavelmente receberam o apoio de tropas pessoais. Otanes possivelmente era o líder de um grupo formado por nobres que se opunham à centralização política imposta pela gestão de Cambises e posteriormente também adotada pelo mago (EVANS, 1981: 81). Dario, por sua vez, devia integrar um grupo partidário da restauração da dinastia aquemênida, da qual ele próprio fazia parte e certamente seria beneficiado com a queda do usurpador. Não haveria necessariamente, nesse caso, um interesse pela descentralização, mas sim por uma questão dinástica. Se considerarmos essa premissa correta, temos, então, o choque entre duas elites oligárquicas/aristocráticas que buscavam formas de ter seus interesses atendidos após a vitória contra o falsário.

Esse primeiro embate entre Dario e Otanes termina com a vitória do aquemênida, uma vez que o grupo decide atacar imediatamente, cedendo à pressão do sétimo conspirador. Heródoto reproduz um suposto diálogo no qual ele afirma ser fácil entrar no palácio justamente por serem nobres, e, portanto, não teriam dificuldade para passar pelos guardas sem a necessidade de confronto (III.72). Dario recebe apoio de Góbrias, que ao lado de Otanes e Aspatines dera início à conspiração. Ele defende que o momento era, de fato, o mais adequado para tomar o poder ou morrer tentando - numa evocação de que os nobres conspiradores concluiriam a missão ou dariam suas vidas para a causa, fazendo uma alusão à virtude dos aristocratas.

$\mathrm{Na}$ sequência, Heródoto afirma genericamente que todos concordaram - sem esclarecer se Otanes fora de fato convencido a atacar Smérdis imediatamente (III.73). De qualquer forma, o apoio de Góbrias a Dario pode representar uma coalizão não apenas entre os dois, mas sim entre as facções comandadas por eles, com o objetivo de derrotar um inimigo comum (a exemplo do que fizeram Mégacles e Licurgo em Atenas, na ocasião do primeiro exílio de Pisístrato).

Porém, haveria ainda um segundo confronto entre as ideias de Dario e Otanes, por conta da revelação feita na Pérsia de que Smérdis era um falsário, e não o filho legítimo de Ciro (III.74-75) - fato até então desconhecido pela maioria dos persas. Heródoto afirma que os adeptos de Otanes se mostraram favoráveis a aguardar e não atacar naquele momento, para compreender melhor a situação; enquanto isso, o grupo que apoiava Dario defendeu o contrário (III.76). Nesse caso, o historiador narra que os 
sete conspiradores já tinham assumido posições claras em apoio a Otanes e Dario, resultando em uma bipolaridade política. Novamente, podemos interpretar que cada um dos sete persas tinha consigo o apoio de outros nobres e, principalmente, de forças militares.

A própria Inscrição de Behistun nos ajuda a fundamentar essa afirmação, uma vez que no documento autobiográfico o próprio aquemênida afirma que houve um confronto entre os conspiradores e os homens Smérdis $(D b, 13)^{51}$. Essa versão indica que houve uma guerra civil entre os grupos comandados pelos conspiradores e os defensores do mago.

Dessa forma, é possível interpretar que os persas rebelados contra Smérdis formavam facções próprias e com interesses próprios, e que eles construíam alianças a partir do momento em que identificavam interesses e necessidades comuns. Entretanto, as divergências podiam levar ao caos, que só poderia ser superado a partir da ascensão do governante único - assim como ocorreu em Atenas.

Mais uma vez, Otanes saiu perdedor da disputa contra Dario. A terceira e última derrota seria o próprio debate persa, quando a sua defesa do governo popular perdeu a disputa para a proposição monarquia do aquemênida.

Neste segundo capítulo buscamos, portanto, mostrar como Heródoto constrói o pensamento político acerca das formas de governo que posteriormente seriam expostas na fala dos três persas em III.80-82. Tivemos a oportunidade constatar que nos antecedentes do debate persa o historiador esboça um juízo valorativo negativo do governante único, ao usar, sobretudo, os exemplos de Cambises e Smérdis para denunciar ao leitor os excessos cometidos por eles. Seria essa hýbris - envolvendo o desrespeito às leis e à religião, além da arbitrariedade das decisões - que justifica o fato do regime tirânico ser classificado como negativo pelo autor.

Em contrapartida, o modelo antagônico da monarquia/tirania, ou seja, a democracia, é apresentada a partir de um juízo valorativo positivo, uma vez que se trata de uma ideologização do regime democrático ateniense. Heródoto é partidário da ideia de que o governo da maioria é positivo, pois possui características libertadoras, enquanto a tirania resulta em centralização e opressão. Essa comparação é importante porque será apresentada também no debate entre Otanes e Dario, posteriormente.

\footnotetext{
${ }^{51}$ No documento, Dario afirma que ele e alguns poucos homens derrotaram o mago (chamado de Gauamata na inscrição) e seus seguidores.
} 
Por fim, terminamos o capítulo analisando a oligarquia nas Histórias, uma forma de governo também tratada de modo ambíguo pelo historiador, uma vez que aristocracia e oligarquia muitas vezes são usadas como sinônimos na obra. De qualquer forma, percebemos que o governo de poucos funciona como um modelo intermediário entre a centralização e a descentralização de poder. Porém, tivemos a oportunidade de verificar como os grupos aristocráticos/oligárquicos expõem um confronto de interesses particulares, e como esse conflito é instrumentalizado ora em favor do governo, ora contrário ao governante. Essa dinâmica sugere que o governo de poucos é responsável pela situação de caos político nas póleis, que precisa ser superado a partir de um novo ordenamento.

No próximo capítulo, vamos analisar diretamente o debate persa, verificando como Heródoto trabalha com a reprodução das supostas falas dos nobres, além de estudar como os diálogos de Otanes, Megabizo e Dario são construídos pelo historiador, a partir de uma perspectiva da teoria e da filosofia política. Essa etapa da dissertação é importante para mostrarmos como é possível interpretar o debate por uma perspectiva diferente da tripla classificação das constituições, mas sim a partir de uma hexa classificação, que leva em conta elementos positivos e negativos sobre cada governo proposto no diálogo, resultando em formas de governo positivas e negativas - debate teórico que antecipa o que fariam, por exemplo, Aristóteles e Políbio posteriormente. 


\section{Capítulo 3: A teoria política sobre o debate persa}

\subsection{Introdução ao debate persa}

No capítulo anterior, apresentamos uma possível interpretação para a construção do pensamento político de Heródoto nas Histórias acerca das formas de governo, que acaba se reproduzindo, de certa forma, no debate persa em si. No próprio livro III da obra, percebemos que o historiador constrói uma concepção de monarquia bastante negativa, tendo como exemplos os governos de Cambises (considerado louco, sacrílego e um governante que abusa do poder) e Smérdis (um usurpador, que chegou ao trono por meio da mentira e do golpismo). Concluímos que o juízo valorativo é negativo, pelo menos dentro deste contexto, porque o autor ressalta em várias passagens os aspectos considerados amorais do comportamento dos governantes em questão - sob um ponto de vista helênico.

Heródoto, ademais, não cria nenhuma tipologia que diferencie os governos monárquico e tirânico, logo, os exemplos dos monarcas persas servem como modelos políticos tirânicos dentro desse contexto estudado no capítulo anterior. O mesmo problema é visto nos casos da oligarquia e aristocracia, também confundidos pelo autor. O motivo é que, provavelmente, os conceitos acerca das constituições eram fluidos no tempo do historiador - o que não o levou a ter uma concepção clara a respeito das mais diversas formas de governo, optando por trabalhar com as tipologias mais consagradas na época, embora, de forma não-sistematizada, ele proponha novas possibilidades de interpretação, como veremos neste capítulo.

O juízo valorativo negativo da tirania/monarquia contrasta com a experiência política antagônica, a democracia. Esse conflito ideológico é construído dentro de um contexto de memória ateniense. Vimos, por meio da análise do livro $\mathrm{V}$, a construção do juízo valorativo do governo popular, especificamente em um contexto de Atenas - no qual a discussão sobre essa forma de governo foi fundamental para a formação política da geração de Heródoto e para a criação de uma identidade ateniense/grega, em contraste a uma identidade bárbara (o que, no limite, remete à distinção entre a liberdade e o despotismo, segundo a visão dos autores helenos).

Deste modo, o segundo capítulo nos possibilitou analisar a construção do antagonismo entre esses dois modelos políticos pelo historiador, classificando um como bom, enquanto o outro aparece como ruim. Esse embate ideológico vai se reproduzir no 
discurso dos três persas em Heródoto III.80-82, ora como uma defesa da monarquia ante a democracia, ora em uma situação oposta.

Neste terceiro capítulo, vamos trabalhar diretamente sobre o debate persa, mas aplicando a teoria política esboçada por Heródoto acerca da tirania e da democracia de forma mais ampla, demonstrando como o fragmento III.80-82 contribuiu para a teorização das formas de governo de modo a introduzir na documentação helênica um pensamento sobre as diversas constituições. Nossa ideia é utilizar esses conceitos na análise dos discursos dos três persas de modo a compreender como o autor utiliza a reprodução das falas para desenvolver seu pensamento político sobre as constituições mesmo tendo feito isso de forma não-sistematizada. Veremos, por exemplo, que a tripla classificação dos governos pode, na realidade, ser compreendida como uma hexa classificação, considerando a possibilidade da elaboração tanto de uma teoria positiva quanto negativa de cada modelo constitucional mencionado no debate - tudo porque os nobres persas, em suas falas, sugerem a existência das três formas de governo devidamente tipificadas por Heródoto (monarquia, oligarquia e democracia), contudo, apontam indícios da existência de outros três modelos, mas desta vez sem nomeá-los especificamente: tirania, aristocracia e oclocracia. Alguns autores, como Romilly, já indicavam para essa possibilidade, referindo-se especificamente à influência da tradição sofista de representar cada constituição com dois aspectos, um positivo e outro negativo, criando uma interpretação que leva em conta os governos bons e maus, muito embora nenhum autor tenha sistematizado os seis governos até Platão, Aristóteles e Políbio (ROMILLY, 1959: 82).

Bobbio afirma que há, em Heródoto, uma teoria positiva e outra negativa: cada persa descreve uma constituição de forma positiva e outras duas de forma negativa, indicando a existência, portanto, de seis regimes políticos no fragmento - que seriam sistematizados posteriormente (BOBBIO, 1985: 41).

Além disso, também podemos concluir, a partir da fala de Dario, especificamente, que há em Heródoto uma espécie de início da teoria cíclica, ou anaciclose, presente no debate, uma vez que fica implícito no discurso do aquemênida (III.82) a ideia de que há uma evolução das formas de governo, criando um fluxo - que, para o persa, conduz os governos oligárquico e democrático a se transformar até a instauração de uma monarquia, capaz de levar ordem à anomia $^{52}$, dando fím à stásis, ou

\footnotetext{
${ }^{52}$ É a passagem da anomia para a eunomia por meio da monarquia, já conhecida no método herodotiano a partir da semelhança com as ascensões de Deioces, na Média, e Pisístrato, em Atenas.
} 
seja, ao conflito civil dentro do Estado. Esse princípio seria sistematizado mais tarde, na obra de Políbio.

Um ponto inicial importante é a opção do historiador em esboçar seu pensamento político, em III.80-82, não como um narrador teoricamente imparcial (ou objetivo), que relata diretamente a teoria, mas sim por meio da reconstrução dos supostos discursos pronunciados pelos nobres persas após a deposição de Smérdis. Metodologicamente, trata-se de uma maneira de agir como porta-voz do outro, dando espaço a uma espécie de polifonia no documento. Um primeiro problema acerca desse método é a impossibilidade de acreditarmos numa fiel reprodução da fala de cada persa, justamente pela falta de documentação sobre o evento, ou mesmo de testemunhas oculares - isso se tomarmos como premissa que os discursos foram de fato pronunciados.

Sobre esse assunto, Meneses Sousa afirma, em um artigo, que

Entre as formas de delegação da palavra aos bárbaros, de reprodução da enunciação do outro, temos os "discursos relatados" em que o locutor se coloca como "porta-voz" do outro, como no caso da narrativa do debate persa que se apresenta como a reprodução dos discursos pronunciados pelos nobres persas que debateram sobre a melhor forma de governo e o regime a ser instituído após a morte de Cambises e a matança dos magos, fato que é datado suposta e provavelmente em 522 a.C., enquanto a data de composição desta narrativa é improvável e se confunde com as datas estabelecidas para os escritos de Heródoto, ou seja, aproximadamente entre 445 e 425 a.C. (MENESES SOUSA, 2009: 85)

Nesse sentido, é preciso considerar a improbabilidade de Heródoto ter conseguido reproduzir fielmente os discursos uma vez que ele não esteve presente durante o debate e provavelmente não teve acesso a testemunhas oculares. Entretanto, o problema da data em si não é o principal. Inclusive porque discutir a plausibilidade da reprodução do discurso, no limite, é entrar na discussão da negação ou da comprovação do fato histórico, já muito discutido em pesquisas. Contudo, o autor ressalta para o fato de Heródoto adotar como método da descrição do outro, no caso os persas, por meio da reprodução de supostos discursos diretos, o que 
(...) não é nem uma possibilidade e nem um ideal historiográfico para os historiadores gregos, na verdade, a prática da reconstituição dos discursos repousa sobre a seletividade. Essa característica de seletividade do discurso histórico é inerente ao uso da narrativa e se a escritura histórica de Heródoto é inseparável da narração, ela necessariamente não pode prescindir de uma seleção dos fatos, de um sistema de escolhas, de valorações, elementos que aparecem na reconstituição do debate persa (MENESES SOUSA, 2009: 85)

A reprodução dos discursos de forma direta é uma impossibilidade justamente por ser um fato muito anterior ao nascimento do próprio historiador, e que não é documentado por nenhuma outra fonte historiográfica. Logo, sabemos que as falas foram construídas pelo próprio autor, independentemente do motivo - investigar as motivações não está nos objetivos desta dissertação, inclusive porque nos levaria a resultados subjetivos e baseados em conjecturas. O efeito dessa opção narrativa, no entanto, é o que nos interessa, pois, a forma adotada pelo historiador para colocar em evidência o choque entre os modelos constitucionais carrega uma série de valores próprios (valores de uma cultura grega/ateniense) acerca das formas de governo e da própria cultura política em si. Sendo assim, a fala de cada persa carrega, inevitavelmente, diversos elementos valorativos atribuídos a Otanes, Megabizo e Dario pelo próprio historiador - criando, assim, um importante texto sobre teoria política clássica.

Além disso, consideramos que o debate persa é o segundo confronto entre os sete conspiradores. O primeiro embate foi descrito pouco antes, quando os nobres se reuniram para decidir se deveriam atacar os magos imediatamente ou aguardar (ASHERI, 2007: 471). O mesmo autor argumenta que o fragmento pode ter de fato sido inventado por Heródoto, porém, ele está completamente integrado ao seu contexto narrativo: a própria oposição ideológica entre Otanes e Dario nos dois debates é uma forma de justificar essa afirmação.

O debate constitucional persa constitui um dos mais antigos tratados de teoria política da história ocidental (ASHERI, 2006: 86; KAGAN apud EVANS, 1981: 79), e essa passagem das Histórias foi responsável, de acordo com alguns especialistas, pela criação de uma tradição importante para o campo da filosofia política (BUTTI DE 
LIMA, 2008: 4). Contudo, não é comum que os especialistas em ciência política o considerem o marco fundador da teoria das formas de governo, justamente por não ser uma teoria sistematizada. Bobbio (1985: 39) e Châtelet, Duhamel e Pisier-Kouchner (1994: 16) talvez sejam os únicos que mencionam as Histórias, respectivamente nos livros Teoria das Formas de Governo e História das ideias políticas, como uma obra inauguradora da discussão do constitucionalismo ${ }^{53}$. O primeiro é um manual sobre o assunto, no qual o cientista político italiano discorre sobre a evolução histórica do debate das formas de governo, partindo de Heródoto até chegar aos pensadores modernos, como Montesquieu. No segundo, um livro mais amplo sobre as origens do pensamento político ocidental, os autores discorrem basicamente sobre a gênese do pensamento político ocidental - partindo dos estudos da Antiguidade até chegar a pensadores e conceitos mais contemporâneos, e menciona a reprodução das falas presentes em III.80-82 como um marco importante para o pensamento constitucional ocidental.

Nenhum outro teórico da ciência política, no entanto, coloca Heródoto na relação dos autores que buscaram compreender a questão das formas de governo. Uma possível explicação é que os cientistas políticos ignoram a obra herodotiana porque o autor não sistematizou a discussão, o que pode não configurar uma teoria devidamente completa acerca do assunto. Outra hipótese é que a apresentação das ideias por meio da reprodução de discursos afeta parcialmente a construção de uma teoria política por deixar muitos elementos implícitos, como o próprio juízo valorativo negativo/positivo das constituições mencionadas.

Entretanto, o autor parece nos oferecer uma leitura muito mais aprofundada do que aparenta sobre as constituições, pois já indica a possibilidade de considerarmos não apenas uma tripla classificação dos governos, mas sim a partir de uma hexa tipificação, na qual as formas de governo podem ser divididas em três modelos legítimos, ou seja, aqueles pelos quais os governantes ocupam os cargos de modo a governar para o bem comum, e três modelos ilegítimos, nos quais as preocupações dos administradores públicos não estão voltadas, necessariamente, para o benefício da comunidade.

\footnotetext{
${ }^{53}$ Considerando constitucionalismo, neste caso, como sendo o estudo da "divisão de poder, de modo que se impeça todo tipo de arbítrio"; (...) "o constitucionalismo representa o governo das leis, e não dos homens, da racionalidade do direito e não do mero poder" (MATTEUCCI, 1998: 248, in: BOBBIO, Norberto; MATTEUCCI, Nicola; PASQUINO, Gianfranco. Dicionário de Política. Brasília: Editora UnB, 1995).
} 
Logo, propomos a possibilidade de interpretar o debate persa em Heródoto de uma forma semelhante, porém não-sistematizada, da discussão que Aristóteles faria posteriormente no terceiro livro de sua Política, fragmento no qual discute justamente a existência de uma hexa classificação das formas de governo. Isso é possível porque os persas em Heródoto III.80-82 trabalham de forma a apresentar argumentos e contraargumentos uns em relação aos outros. Deste modo, o governo popular defendido por Otanes resguarda características associadas à democracia; por outro lado, a crítica de Megabizo acerca do governo da maioria apresenta problemas normalmente relacionados à oclocracia. Do mesmo modo, as críticas de Otanes e de Megabizo o governante único utilizam argumentos que remetem à tirania; porém, Dario defende o governo de um utilizando elementos típicos da monarquia. Quanto ao governo de poucos, no entanto, é possível encontrar argumentos contraditórios no próprio capítulo 81: quem indica ser uma oligarquia é o narrador (Heródoto), enquanto na fala do próprio Megabizo há a indicação de que se trata de uma defesa do modelo aristocrático.

Como a discussão das formas de governo muito provavelmente já era conhecida pelos gregos do período anterior a Heródoto, conforme já discutimos anteriormente, podemos considerar também que a hexa classificação estava presente nas discussões das ágoras. Portanto, a construção do pensamento político herodotiano, a partir de III.8082, indica que o início da teorização acerca desse assunto já era conhecido - assim como a discussão acerca da evolução das formas de governo.

Para Bobbio (1985, p. 33), essa discussão passa por duas esferas analíticas distintas, uma de caráter descritivo e outra de natureza prescritiva. O elemento descritivo seria criar as tipificações de cada uma das formas de se governar um Estado. Como já mencionamos, nesse aspecto o historiador provavelmente reproduziu a tipificação das formas de governo consagradas no seu tempo. Certamente, Heródoto escreveu sobre um problema contemporâneo de sua época, ou seja, a discussão sobre as constituições já existia. O historiador não deve ter sido, portanto, o primeiro a levantar essa questão. Entretanto, ele foi pioneiro na escrita do tema, dando início à sua teorização. Possivelmente era um tipo de assunto bastante comum nas póleis gregas, mas que ainda carecia de uma análise teórica, mesmo que de forma não-sistematizada, como fez o historiador. Já o elemento prescritivo provém do exercício de analisar, criticar e qualificar cada uma das formas de governo como boas ou más, seguindo determinados critérios. 
Partindo dessa premissa, podemos admitir que a discussão sobre as formas de governo ocupava um lugar importante no pensamento grego, sobretudo ateniense, do período pós-Guerras Médicas. O motivo era a necessidade de compreender a própria realidade/identidade política, em oposição ao invasor estrangeiro. Esse contexto é importante para sabermos que Heródoto vivia num ambiente no qual a questão muito provavelmente era constantemente debatida não apenas na ágora, mas também em diversos outros momentos da vida social da pólis. Segundo Roy, Heródoto III.80-82 revela que no quinto século a.C. a classificação das formas de governo era bastante familiar aos gregos, que

já descreviam aquelas constituições em termos de como o poder era distribuído, e que eles faziam a distinção entre o governante racional e o impulsivo, o mau governante. (...) A apresentação de Heródoto é valiosa porque mostra que um historiador pode oferecer a compreensão do desenvolvimento do debate constitucional (...) (ROY, 2012: 298-299)

A justificativa para isso é que as Guerras Médicas colocaram os gregos em contato com um novo tipo de sociedade. Essa integração contrapunha, pela visão ática, a democracia à monarquia - comumente confundida com a tirania pelos próprios escritores gregos, como Heródoto, que praticamente não faziam distinção entre as duas formas de governo ${ }^{54}$.

Alguns autores consideram que o debate persa integra o conjunto de narrativas da etnografia persa de Heródoto ${ }^{55}$ (PELLING apud ROY, 2012: 299), num importante momento descritivo dos valores políticos persas sobre governo. Partindo desse ponto de vista, Sydnor Roy sugere que o fragmento convida a audiência de Heródoto a olhar o debate "com um pouco de distanciamento e talvez mais abstração" (2012: 299). Desse modo, o autor argumenta que isso não elucida o nosso problema contemporâneo sobre a questão, mas que provavelmente ajudava o público grego a pensar sobre sua própria escolha para o futuro político da pólis. Ou seja, Heródoto teria instrumentalizado o

\footnotetext{
${ }^{54}$ Aristóteles, por sua vez, rompeu com essa tradição no livro III de Política e definiu que a monarquia era o governo de um só, cujo governante trabalhava em benefício da comunidade. A tirania, por outro lado, seria a forma degenerada, na qual o governante único visava apenas o benefício próprio. A teoria das formas de governo em Aristóteles é uma das mais estudadas pelos autores contemporâneos da ciência política.

${ }^{55} \mathrm{Ou}$ seja, dentro de uma grande lógica narrativa da história da Pérsia, em um amplo lógos.
} 
discurso dos persas para chamar a atenção para questões internas das póleis. Thompson argumenta que Heródoto não tinha clareza da concepção de regime político persa (1996: 53). Asheri complemente, dizendo que a fonte do historiador deveria ser, possivelmente, ateniense, uma vez que a polêmica sobre as formas de governo tinha lugar em Atenas, no mesmo período (2006: 86).

É um ponto de vista interessante, que coloca, em nossa opinião, novamente o uso das analogias de eventos ocorridos na Hélade dentro de um conjunto narrativo de outro contexto (HARTOG, 1999: 242-244), de modo a instrumentalizar o debate e provocar uma discussão dentro do território heleno.

$\mathrm{O}$ fato de o debate persa possuir marcas da retórica argumentativa grega ajuda a corroborar com essa hipótese. A fórmula adotada por cada um para expor seus argumentos é a mesma: expor possíveis falhas das outras duas formas de governo e enaltecer as qualidades daquela que defende. Contudo, novamente, seria uma análise da estrutura literal - e não da teoria política, que é o nosso objetivo.

Para isso, vamos, agora, nos dedicar ao estudo do fragmento em si para, em seguida, nos apoiar na filosofia política, sobretudo nas obras de Aristóteles e Políbio, para compreendermos as influências do debate constitucional presente nas Histórias.

Vamos, nas próximas três sessões, analisar separadamente o discurso de cada um dos três persas, de modo a verificar, com o suporte da filosofia e da teoria política, como fala ajuda a construir a hexa classificação das formas de governo na obra herodotiana. 


\subsection{O discurso de Otanes}

Comecemos a análise do fragmento com o discurso de Otanes, o primeiro conspirador a se manifestar sobre o futuro do governo da Pérsia após a execução do usurpador e dos magos. Trata-se, segundo Heródoto, do aristocrata que deu início à conspiração dos sete, ao descobrir a verdade sobre o falso Smérdis e reunir os primeiros aliados na tentativa de depor o falsário - e aquele que, nos antecedentes do debate, já havia confrontado Dario em duas oportunidades (Hist., III.71-72 e III.76), ambas demonstrando um comportamento político antagônico ao do aquemênida.

Antes de introduzir a reprodução do discurso, Heródoto, assumindo a função de narrador, alerta sua audiência quanto à estranheza da fala que viria a seguir. $\mathrm{O}$ autor afirma que muitos duvidariam do que foi dito - provavelmente aludindo que os leitores gregos estranhariam o fato de três persas debaterem sobre a melhor forma de governo para a Pérsia. Isso reforça os argumentos de que o debate persa fala grego (MURARI PIRES, 2012: 183), inclusive porque sua audiência era composta por helenos.

Além disso, antes da fala do persa Heródoto indica que houve um intervalo de cinco dias entre a morte do mago e o debate constitucional. Alguns autores consideram que esse interregno corresponde a um período de anomia, ou seja, de ausência de leis, comum às Histórias ${ }^{56}$.

O historiador de Halicarnasso reproduz a arguição de Otanes sobre o governo popular da seguinte maneira:

Quando o tumulto cessou e passados cinco dias, os persas que estavam rebelados contra os magos deliberaram conjuntamente sobre a situação; e os discursos pronunciados são considerados incríveis por alguns helenos, mas eles foram realmente pronunciados.

Otanes pleiteou a entrega do governo ao povo persa; ele disse: "Minha opinião é de que um único homem não tem mais que governar sobre nós com a autoridade monárquica; isso nem é bom e nem agradável. Vocês viram efetivamente em que ponto chegou o orgulho insolente de Cambises, e vocês viram, também, a insolência experimentada pelo mago. Como a monarquia seria bem organizada, se ela admite que o governante faça o que quiser, sem prestar contas de seus

\footnotetext{
${ }^{56}$ Em I.97, na descrição da ascensão de Deioces, por exemplo. Na passagem, Heródoto narra que houve um período de ausência de leis e justiça, configurando uma situação de caos que só pode ser ordenada a partir da métis (astúcia) do novo governante único.
} 
atos a ninguém? $\mathrm{O}$ melhor homem do mundo, investido deste tipo de autoridade, seria conduzido para fora de seus pensamentos habituais. A prosperidade que ele goza faria nascer nele essa insolência orgulhosa; e a natureza fez os homens invejosos desde a sua origem. Tendo esses dois defeitos, a monarquia resguarda em si toda a maldade; repleto de orgulho, o monarca comete muitos atos loucamente criminosos; o mesmo ocorre por conta da inveja. Um tirano, na realidade, deveria ignorar a inveja melhor que os demais, pois ele possui todos os bens; mas sua atitude de invejar os cidadãos exprime justamente o contrário: ele inveja a maneira de conduzir-se e de viver dos homens de bem; ele se compraz com a pior parte da população, e ele é muito duro para acolher as calúnias. Ninguém é mais inconsequente: se você o admira moderadamente, ele o verá como alguém que não o admira o suficiente; e se o cortejo é demasiado, ele o verá como um adulador vil. E eu vou dizer o que há de mais grave: ele subverte os costumes ancestrais, violenta as mulheres e condena à morte sem julgamento. Em contrapartida, o governo do povo, em primeiro lugar, carrega consigo o mais belo dos nomes: isonomia. Em seguida, ele não comete nenhum dos excessos do monarca: nós obtemos as magistraturas por sorteio, somos responsáveis pela autoridade que exercemos e todas as deliberações são submetidas ao público. Proponho, então, que renunciemos à monarquia, e que elevemos o povo ao poder, pois tudo reside na maioria." (Hist., III.80)

Uma primeira observação é que, segundo Myers (1991: 543-544), o principal argumento do discurso de Otanes é, na realidade, uma aspiração dos democratas no que diz respeito à justiça. Essa justiça, para o autor, é definida pelo persa apenas como um governo livre de opressões arbitrárias - de modo que o discurso nem sequer mencione conceitos como desigualdade econômica. Apenas o aspecto político é utilizado durante a argumentação, ou seja, fica implícito que, segundo Otanes, a centralização política é nociva à comunidade política. Nesse sentido, o termo isonomia é empregado como sinônimo de política anti-tirânica baseada na ideia de distribuição igualitária de poder político (ASHERI, 2007: 474).

Em segundo lugar, a maioria dos intérpretes do debate persa considera que a fala de Otanes dialoga diretamente com a audiência grega mais do que as outras duas falas, inclusive pela presença de expressões presentes em discursos políticos gravados na memória ateniense dos primórdios da democracia, na passagem do século VI a.C. para o 
V a.C. O principal argumento que sustenta essa ideia é o fato do nobre se valer do mesmo tipo de crítica à monarquia/tirania presente nos antecedentes do próprio debate persa, e enaltecer pontos supostamente positivos do governo do povo.

Desta forma, o discurso de Otanes começa com uma dura crítica ao governante único, que não seria apropriado por conta dos atos extremos cometidos por Cambises e Smérdis - já debatidos no segundo capítulo desta dissertação. O persa, inclusive, dá a entender que a tirania, de forma geral, é um governo marcado por excessos, como a possibilidade de que o tirano cometa desrespeitos às leis e costumes - simbolizando que, segundo essa interpretação, um governo monárquico jamais seria orientado para o bem do estado e da população. A fala de Otanes, portanto, constrói um juízo valorativo negativo acerca da tirania.

Nesse sentido, o termo hýbris é utilizado por Heródoto - na reprodução da fala de Otanes - como forma de denúncia contra os excessos monárquicos/tirânicos atribuídos aos governantes persas utilizados como exemplos.

De acordo com Meneses Sousa

Essa expressão (hýbris), largamente utilizada por Heródoto para designar as atitudes dos soberanos bárbaros nas Histórias, é típica do vocabulário da tragédia grega e diversos autores já notaram a importância da tragédia no nascimento da história, particularmente na obra de Heródoto, que tem como referências enunciativas os relatos trágicos das guerras medas (...). A caracterização do poder monárquico ou tirânico no discurso de Otanes é trágica, tendo em vista que o personagem trágico é um ser tomado pela hýbris e o poder monárquico ou tirânico no discurso de Otanes é o próprio lugar da hýbris. (MENESES SOUSA, 2009: 89-90)

Para exemplificar a crítica de Otanes, Heródoto recorre a alguns exemplos práticos quanto à atuação de Cambises e do mago, tais como a subversão dos costumes ancestrais, o estupro e a arbitrariedade na condenação à morte. Embora os termos monarquia e tirania sejam confundidos no discurso, podemos considerar que esses elementos apresentados por Otanes fazem menção não a um governo monárquico, mas sim a um tirânico. As características presentes nessa fala estão associadas com o uso excessivo do poder político centralizado - que neste caso está concentrado nas mãos de um único indivíduo. Pela lógica do discurso, esse tipo de abuso só foi cometido porque 
o governante único não precisa prestar conta de seus atos à população, de modo que ele possa governar pensando unicamente em suas vontades, e não no bem da comunidade política.

Conforme já mencionamos, provavelmente havia uma fluidez quanto às tipologias no período, e as formas de governo não compunham categorias muito bem definidas no tempo de Heródoto. Porém, a discussão já existia, embora não tivesse sido sistematizada. Logo, se tomarmos como base a classificação das constituições proposta posteriormente por Aristóteles, já no século IV a.C., temos um indicativo de que o historiador de Halicarnasso construiu uma crítica à tirania, e não à monarquia, no discurso de Otanes - sem, no entanto, a classificar como tal. É desse modo que o filósofo de Estagira argumenta sobre as diferenças entre os dois governos formados por um indivíduo:

Nós chamamos comumente de realeza aquelas monarquias que tem em vista $o$ bem comum, e aristocracia o governo de um pequeno número de homens, mas não de uma única pessoa, seja porque são os melhores no poder, ou porque seu poder tem como objetivo o bem maior da pólis e de seus membros; quando a massa governa a cidade em vista do bem comum, nós damos a esse governo o nome de politéia (...) Os desvios que correspondem às constituições enumeradas são a tirania, desvio da monarquia; a oligarquia, da aristocracia; e a democracia, da politéia. (...) Uma tirania é, como já dito, uma monarquia governando despoticamente a comunidade política. (ARISTÓTELES, Pol., III, VII.3-5, VIII.2)

Essa passagem de Política indica que Aristóteles tinha uma preocupação com a autoridade política (TAYLOR, 1995: 233), ou seja, com o modo pelo qual o poder é distribuído (para um, para poucos ou para a maioria) e a forma como era empregado dentro da sociedade. Nesse sentido, é possível julgar como a constituição organizava os diversos atores políticos, de modo a verificar como a autoridade era exercida, se para o bem comum ou não (SHIELDS, 2007: 364; TAYLOR, 1995: 240).

O tipo de argumento utilizado por Otanes em III.80 na crítica ao governante único corresponde, por meio desta associação com Aristóteles, às características tipicamente relacionadas à tirania, ou seja, um governo despótico (como no caso de Smérdis) e sem a preocupação com o bem comum, mas sim em benefício próprio (como 
Cambises). Aristóteles estava, possivelmente, inserido na mesma tradição do estudo das constituições do século V a.C., porém, em um estágio posterior no qual foi possível definir melhor as tipologias - e inclusive criticar a democracia por conta da experiência ateniense no fim do século.

Heródoto, portanto, pode não ter distinguido as duas formas de governo de forma sistemática, não criando uma tipologia específica para cada uma, mas deixou implícita a existência de uma variedade da monarquia - que segundo a fala de Otanes, os antecedentes do debate persa e a continuidade dessa tradição por Aristóteles, indica ser uma tirania, ou seja, um governo carregado de características negativas e que não exaltam a virtude do governante imbuído no cargo. Logo, o texto herodotiano traz uma reflexão política um pouco mais complexa do que uma análise descuidada do fragmento permite constatar.

Nesse aspecto, o tirano criticado por Otanes é um tipo de governante que despreza regras e recusa os princípios de igualdade social e civil, causando como efeito uma espécie de anomia política na sociedade. A hýbris do tirano, portanto, vai contra a tradição ética presente no pensamento político grego, relacionada à moderação e à harmonia políticas (MENESES SOUSA, 2009: 90). Essas características vão em direção contrária à condição política possibilitada pela isonomia - na igualdade perante a lei, proposta pelo persa.

Logo depois de apresentar as críticas contra a tirania, o historiador apresenta os argumentos favoráveis ao governo popular. Heródoto não menciona no debate persa a tipologia "democracia". Entretanto, uma análise dos argumentos utilizados por Otanes leva à compreensão de que esse governo popular seria de natureza democrática, seguindo moldes conhecidos pelos atenienses após as reformas de Clístenes e que, por sua vez, representam basicamente uma oposição à própria tirania, compondo assim o antagonismo constitucional.

O conceito da isonomia é um dos principais indícios que levam à constatação de que Heródoto se refere ao governo clisteniano. O motivo é que, na fala de Otanes, há alguns elementos que podem ser associados ao modelo democrático ateniense que se tornara motivo de orgulho para uma parte considerável da população de Atenas. Segundo o discurso, o persa propõe que a igualdade perante a lei possibilitaria o combate às injustiças e às decisões arbitrárias do governante único, além de possuir sistemas pelos quais as decisões políticas seriam tomadas em debates na assembleia e os 
cargos públicos seriam distribuídos por meio de sorteios. Essas são características comuns à democracia ateniense originária do fim do século VI a.C., que chega a seu apogeu no século V a.C.. Esse modelo pressupõe que existe uma distribuição de poder dentro da pólis, evitando a concentração nas mãos de um único indivíduo. Pelo fragmento - e pela contextualização da democracia apresentada no capítulo anterior Heródoto parece ser tributário de uma tradição favorável a essa forma de governo.

De qualquer forma, é preciso considerar que o termo "democracia" talvez ainda não tivesse sido popularizado na época. Portanto, Heródoto utiliza a palavra "isonomia" como uma espécie de sinônimo, embora seja um termo distinto e historicamente anterior à democracia. Desta forma, é aceitável interpretá-lo como uma equivalência à partilha de poder, ou simplesmente como forma de indicar um governo conceitualmente oposto à tirania (ASHERI, 2007: 474). Nesse aspecto, de acordo com Ehrenberg (1950: 526), a teoria que orienta o debate parece ser orientada por uma espécie de "tiranofobia", uma vez que o contexto ateniense recente - da deposição dos filhos de Pisístrato - norteia boa parte da concepção herodotiana acerca da contraposição entre os dois modelos constitucionais expressos no debate.

Por fim, antes de defender veementemente a democracia como alternativa ao governante único, o discurso de Otanes ainda afirma que no governo popular os indivíduos se tornam responsáveis por seus atos políticos quando estão no exercício das funções públicas. Isso remete ao bom uso do poder político, uma característica tipicamente associada à democracia ateniense - e não à oclocracia, que corresponderia ao uso abusivo do poder por parte da maioria da população, ou seja, à hýbris da turba ou das massas - que governaria de forma irresponsável.

Em síntese, podemos dizer que o governo popular proposto por Otanes tem três características da democracia de Clístenes em Atenas. A primeira seria a escolha por sorteio; a segunda, a responsabilidade dos agentes públicos pelos cargos exercidos; a terceira, por fim, a legitimação das decisões em assembleia. São argumentos que fazem referência a uma espécie de cidadão ideal do Estado democrático (MYERS, 1991: $544^{57}$ ): aquele que sabe seu lugar dentro da comunidade política e que, além disso, toma decisões de forma racional e consciente, sempre orientado para o bem comum. Esse

\footnotetext{
${ }^{57}$ Myers (1991: 544-545) afirma que o discurso de Otanes em defesa da democracia possui, de fato, um caráter moral que indica o cidadão democrático ideal. Porém, a mesma fala apresenta um elemento que ele classifica como hipócrita, que é o reflexo do persa ser um bom exemplo para a personificação do "humor popular". É que, com a vitória de Dario e da monarquia no debate, Otanes afirma que não quer nem comandar e nem ser comandado (III.83), em sinal claro de descontentamento com a derrota.
} 
modelo democrático criado por Clístenes, proposto supostamente por Otanes e que de certa forma está presente também no conceito de politéia de Aristóteles, depende, portanto, do interesse virtuoso do cidadão para que o regime funcione de forma adequada (TAYLOR, 1995: 240). Do contrário, a constituição poderia se degenerar a ponto de ser convertida em uma democracia, que segundo a concepção aristotélica seria um desvio constitucional (Pol., III.VIII.1), ou seja, um governo administrado pelos pobres, e não pelos melhores e mais virtuosos (SHIELDS, 2007: 356). Ou, segundo Políbio, poderia ser classificada como uma oclocracia, um governo da maioria, porém, desordenado (POLÍBIO, Hist., VI.II.4) ${ }^{58}$.

Por fim, a conclusão do discurso do persa, de que "tudo reside na maioria" (III.80), faz novamente uma referência implícita à democracia ateniense. O conceito pressupõe que a democracia opera tanto no sentido de atender a maior parte dos cidadãos (o bem comum, mencionado por Aristóteles), mas também de modo a ser uma expressão da vontade da maioria dos cidadãos. É possível afirmar que o poder nas mãos e os argumentos contrários à tirania possuem diversos paralelos nas Histórias, sobretudo no contexto da isonomia/democracia ateniense presente em V.78 (ROY, 2012: 301) - o que demonstra o pensamento político herodotiano sendo elaborado em um amplo contexto na obra.

Retomando os argumentos de Bobbio, de que o estudo das formas de governo possui um aspecto descritivo e um prescritivo, podemos considerar que Heródoto descreveu apenas uma tipologia de governo único, que seria a monarquia, entretanto, implicitamente prescreveu uma tirania.

Neste embate ideológico apresentado por Heródoto, através da fala de Otanes, vemos que o fragmento discute não apenas a forma como o poder é distribuído, ou seja, na quantidade de participantes do jogo político, mas também no modo como as decisões são tomadas: se racionais ou impulsivas, orientadas para o bem comum ou para o bem do governante (ROY, 2012: 299).

\footnotetext{
${ }^{58}$ Políbio argumenta que existem seis formas tradicionais de governo, três boas e três más. Além delas, há uma sétima constituição, que é o chamado governo misto (BOBBIO, 1985: 66), a forma de governo da República de Roma, na qual existe uma mescla entre elementos com características monárquicas (cônsules), aristocráticas (senadores) e democráticas (tribunos).
} 


\subsection{O discurso de Megabizo}

Após o discurso de Otanes em favor da adoção de um governo popular, Heródoto relata que foi a vez de Megabizo expor a sua opinião. Trata-se de um persa que aderiu à conspiração a convite de Gobrias (III.70). A fala desse nobre indica implicitamente, mais uma vez, a ideia de que existem formas de governo legítimas e seus desvios respectivos desvios constitucionais. É mais uma demonstração de que o historiador de Halicarnasso elaborava um pensamento político acerca da hexa classificação dos governos, e não apenas a respeito da tripla tipologia.

Heródoto nos apresenta o discurso do segundo conspirador a debater da seguinte forma:

Essa foi a opinião apresentada por Otanes. Mas Megabizo queria confiar o governo a uma oligarquia; ele disse: "Quando Otanes aconselha a abolição do regime tirânico, concordo com suas palavras; mas quando ele pediu-lhes a entregar o poder ao povo, ele descartou a opinião mais sábia. Pois nada é mais insolente que uma multidão indolente. $\mathrm{E}$, sem contar, escapar da insolência de um tirano para trocá-la pela insolência da população desenfreada é uma coisa que não podemos tolerar de forma alguma. O tirano, se fizer qualquer coisa, o faz com conhecimento de causa; o povo não possui capacidade nem mesmo desse conhecimento. Como poderia ter, de fato, se não recebeu instruções de ninguém e nem poderia saber por ele mesmo, e ser empurrado aos negócios públicos ou se lançar a eles sem reflexão, como uma torrente? Que aqueles que desejam mal aos persas adotem a democracia; mas nós, escolhamos um grupo dos melhores homens, e entreguemos a eles o poder; pois, obviamente, nós estaremos entre eles, e é natural a probabilidade que dos melhores homens surgem as melhores decisões." (Hist., III.81)

O modelo do discurso apresentado pelo persa segue a seguinte lógica da fala anterior, apresentando uma crítica e, posteriormente, uma proposta constitucional. Inicialmente, Megabizo concorda com a crítica de Otanes à tirania; em seguida, ataca o governo popular; por fim, propõe à concessão do poder a um grupo restrito, porém, apto para comandar o estado persa.

Deste modo, temos um primeiro argumento que corrobora com o ponto de vista de Otanes acerca do governante único. Assim como no primeiro discurso, Heródoto 
elabora uma crítica contra a tirania, e não contra a monarquia. O motivo é que a fala de Megabizo também evoca o problema da hýbris da constituição tirânica, cujo principal problema seria a insolência do tirano. Deste modo, seria uma forma de governo não orientada para o bem comum, configurando, portanto, um desvio constitucional - caso utilizemos o modelo aristotélico como exemplo, pois o próprio Heródoto não elabora a diferença entre monarquia e tirania na fala de Megabizo, da mesma forma como não o fez no caso de Otanes.

Além disso, ao afirmar laconicamente que concorda com as palavras de Otanes, fica subentendido no discurso do segundo persa que também há críticas quanto ao desrespeito às leis e aos costumes, à violação de mulheres e à condenação à morte de forma arbitrária sem a realização de julgamentos - todos argumentos utilizados por Otanes para atacar a tirania. Deste modo, podemos compreender que a hýbris tirânica, segundo Megabizo, também seria responsável por causar esses problemas à Pérsia. Embora não cite exemplos, essa segunda fala possivelmente também é fundamentada pelas críticas a Cambises e Smérdis presentes nos antecedentes de um contexto mais amplo do debate persa.

Megabizo, porém, concorda com Otanes apenas no que diz respeito ao governante único. O persa rompe com o discurso do outro conspirador ao questionar a eficiência do governo popular, também a acusando de resultar em insolência. Heródoto, porém, não parece se referir à democracia nesse fragmento. Os conceitos utilizados para desmontar o argumento positivo ao governo popular indicam se tratar, na realidade, de uma oclocracia. Dois elementos, basicamente, levam a esse tipo de conclusão. O primeiro é a referência à multidão desenfreada. O segundo é a acusação de que o povo não seria apto a governar por falta de instrução e de capacidade de aprender o exercício de governo sozinho - de modo a se lançar cegamente na condução dos negócios do estado.

Esses dois argumentos indicam que há, também, uma hýbris relacionada ao governo popular, que qualifica negativamente as ações dos indivíduos numa democracia e remetem à memória e à experiência política na pólis ateniense (MENESES SOUSA, 2009: 93). Essa crítica à democracia - ou ao seu desvio constitucional - talvez fosse comum à realidade de Atenas no período de Heródoto, uma vez que o governo popular nunca foi unanimemente considerado como sendo a melhor constituição. O modelo democrático também enfrentava oposição dentro da cidade, e o uso desenfreado de seus instrumentos, como o ostracismo, por exemplo, poderiam servir como base para 
fundamentar a crítica contra uma espécie de experiência radical da democracia. Essa constituição ganha a tipologia, para alguns autores, de oclocracia, ou seja, o poder da turba ou da multidão. Partindo desta premissa, é possível pensar, portanto, que a subversão do governo democrático também era conhecida pelos gregos da geração de Heródoto - embora ainda não houvesse uma tipologia específica para essa forma de governo desviada. Talvez tudo fosse tratado como democracia: democracias boas e ruins. Não havia, provavelmente, uma discussão mais complexa, que acenava para a possibilidade de uma espécie de democracia ilegítima, por assim dizer.

No que diz respeito ao governo popular e à tradição política acerca de suas características e derivações, os filósofos gregos das gerações posteriores a Heródoto possuem interpretações distintas. Aristóteles, por exemplo, também trabalha com a existência de dois modelos de constituição popular, uma justa e outra desviada. Contudo, o autor não classifica a democracia como um governo positivo. Pelo contrário. O filósofo prescreve a politéia como sendo o bom governo da maioria, orientada para o bem comum dos cidadãos e para o benefício da comunidade política (Pol., III.VII.3), enquanto a democracia seria sua forma desvirtuada, que buscava angariar benefícios para os indivíduos desprovidos de posses - em detrimento do bem coletivo (Pol., III.VIII.1). A ideia é que esses homens desprovidos de posse se transformariam na maioria da população, e sua hýbris os levaria a tentar expropriar os bens dos mais ricos, causado conflito social, ou stásis.

Quando a massa governa a cidade tendo em vista o interesse geral, nós damos a essa forma de governo o nome de politéia, que é comum a todas as constituições; e com razão, pois é possível que um indivíduo, ou um pequeno grupo, se distinga por sua virtude, mas quando é um grande número há mais dificuldade de se buscar a perfeição em todo tipo de virtude: isso, de fato, é encontrado nas massas; é por isso que nesta constituição a autoridade suprema é depositada nas mãos da classe guerreira ${ }^{59}$, participando do governo aqueles que possuem armas. E o desvio que corresponde (...) é a democracia. (ARISTÓTELES, Pol., III.VII.3-5)

Já Políbio, considerado o criador da teoria do governo misto pela maior parte dos autores (LEVORIN, 2001: 4), anotou sua contribuição para o debate constitucional

\footnotetext{
${ }^{59}$ A referência à classe guerreira pressupõe que o cidadão-soldado é habilitado a governar porque ele está habituado a sacrificar seus próprios interesses em detrimento da necessidade de defesa da pólis.
} 
apenas no século II a.C.. Portanto, teve a oportunidade de analisar a questão a partir de outra perspectiva e com um grande distanciamento de tempo e espaço do acalorado debate sobre a democracia ateniense. A tradição sobre as formas de governo chegou até Políbio seguindo basicamente as tipologias clássicas enunciadas por Heródoto (monarquia, oligarquia e democracia), mas, a exemplo de Aristóteles, também encontrou um modo de criar outras classificações, que permitiriam uma análise das constituições a partir da divisão entre as boas e as más. Sendo assim, ele também divide os modelos.

A maioria daqueles cujo objetivo foi instruir-nos metodicamente sobre tais assuntos - distinguir três tipos de constituições -, falam de monarquia, aristocracia e democracia. (...) Portanto, nós podemos afirmar que há seis formas de governo, as três mencionadas acima que estão na boca de todos, e as três que são associadas a elas, quero dizer a tirania, a oligarquia e o governo da multidão (oclocracia). (POLÍBIO, Hist., VI.II.3-5) ${ }^{60}$

Neste caso, é possível perceber uma dualidade clara entre os governos populares. Heródoto, apesar de não criar uma tipologia específica para o desvio constitucional, parece conhecer um modelo - mesmo que teórico - que subverte o poder do povo em uma constituição permissiva, que por ser regida por homens despreparados acaba causando o mal para os persas (HERÓDOTO, Hist., III.82). Essa afirmação implícita nas Histórias nos parece remeter, logo, à oclocracia (que corresponde ao conceito de democracia para Aristóteles).

Ainda pensando no curto discurso de Megabizo, surge também uma distinção teórica não-sistematizada entre os governos oligárquico e aristocrático, que posteriormente seriam tratados pelos autores por meio de duas tipologias distintas, mas que em Heródoto são fluidas e permeáveis.

A primeira questão importante a ser considerada é que, na reprodução de discurso, Megabizo em momento algum afirma que está propondo a instauração de uma oligarquia. O persa não nomeia a forma de governo deste modo. É o próprio Heródoto, como narrador do fragmento, que afirma se tratar de um modelo oligárquico: "Essa foi a

\footnotetext{
${ }^{60}$ Voltaremos a tratar das constituições, para Políbio, na próxima sessão, para demonstrarmos como Heródoto sugere a existência de uma espécie de transformação natural das formas de governo - o que seria elaborado sistematicamente posteriormente, sobretudo por Políbio.
} 
opinião apresentada por Otanes. Mas Megabizo queria confiar o governo a uma oligarquia (...)" (Hist. III.81). O historiador utiliza o termo oligarxíe.

Heródoto não apresenta nenhum tipo de característica para esse governo oligárquico nessa breve introdução à fala de Megabizo. As características do governo de poucos são apresentadas apenas na reprodução da suposta fala do persa. Heródoto, nesse ponto, nos leva a pensar na possibilidade de que a proposta de Megabizo seja, na realidade, a instauração de uma constituição aristocrática (MYERS, 1991: 545). Um dos possíveis argumentos utilizados para sustentar essa ideia é que o discurso utiliza palavras como ariston, arista e kratos, que remetem ao governo dos melhores inclusive porque os termos, se somados, formariam "aristocracia". Além da própria estrutura textual do fragmento, o discurso afirma nessa passagem que o poder deveria ser entregue a um grupo dos melhores persas - que seriam os indivíduos mais aptos a comandar o estado e a tomar as melhores decisões. Há, nesse caso, uma espécie de virtude do grupo, que reforça o argumento de que Megabizo propunha uma aristocracia para a Pérsia, e não uma oligarquia.

A hipótese de que Megabizo defende a constituição aristocrática é sustentada por autores como Sealey, para quem

Assim, oligarquia é o termo usado pelo narrador (Heródoto) e pelo crítico (no caso, Dario), mas é evitado pelo defensor (do governo de poucos). Pode-se inferior que a palavra oligarquia tinha um sabor desagradável, enquanto que aristocracia soava melhor. (SEALEY, 1973: 273-274)

O crítico, mencionado por Sealey, é Dario, que em seu discurso no fragmento seguinte questionaria a eficiência do governo oligárquico ao afirmar que essa constituição leva ao caos por meio da luta (stásis) entre facções (Hist., III.82). Por conta disso, seria mais um tipo de mau governo.

No limite, podemos compreender que a fala de Megabizo nos remete a uma relação intensa entre caos e ordem, envolvendo a tirania e a oclocracia, que levariam a Pérsia para o caos, enquanto a aristocracia seria a responsável por restabelecer o ordenamento político.

Se tomarmos como correta a ideia de que o fragmento III.81 possui essa dupla apresentação do governo de poucos, devemos considerar que a distinção entre oligarquia e aristocracia já era conhecida no tempo de Heródoto, provavelmente 
também em um contexto ateniense. Autores posteriores, como Platão e Aristóteles, sistematizaram, cada um à sua maneira, a análise prescritiva dessas duas formas de governo. Assim, a aristocracia seria definida na obra aristotélica como uma constituição que distribui o poder para poucos indivíduos - ou porque são considerados os melhores ou porque governam pensando no bem da comunidade política e de seus membros (Pol., III.VII.3). O discurso de Megabizo parece indicar que essa é de fato a forma de governo proposta. A contraparte seria a oligarquia, cuja principal característica seria a defesa dos interesses das classes economicamente mais favorecidas (Pol., III.VII.5), ou seja, a manutenção dos privilégios, como a riqueza. Esse ponto é importante dentro de uma perspectiva ateniense porque as reformas de Sólon levaram uma parte dos nobres à miséria com a aprovação da lei que abolia a escravidão por dívidas.

A frase "que aqueles que desejam mal aos persas adotem a democracia" (Hist., III.81), indica, para Myers, que a aristocracia proposta por Megabizo não tinha um caráter universal. Ela serviria apenas para a Pérsia:

"Megabizo não quer que entendamos os benefícios da aristocracia ao exterior da Pérsia; pelo contrário, ele deseja que os inimigos de seu país adotem o regime considerado decididamente inferior, a democracia (III.81). Como o polemarco na República de Platão, Megabizo vê o kalon como princípio para fazer o bem a seus amigos e o mal a seus inimigos" (MYERS, 1991: 546)

Por fim, podemos considerar a observação de Lateiner (1989:168), que se surpreende com o tamanho muito reduzido do discurso atribuído a Megabizo, se comparado à fala de Otanes e, principalmente, à defesa da monarquia proposta por Dario (que não é apenas extensa, mas também complexa quanto às ideias políticas elaboradas por Heródoto nessa passagem). O tamanho reduzido pode indicar a pequena importância do governo oligárquico/aristocrático na elaboração do pensamento político de Heródoto nas Histórias, no que diz respeito ao confronto ideológico entre tirania e democracia. Meneses de Sousa (2009: 95), por sua vez, argumenta que o discurso oligárquico/aristocrático de Megabizo incorpora muitos elementos presentes na fala de Otanes (o que pode justificar a concisão das críticas à tirania/monarquia, pois o que já foi falado anteriormente não precisaria ser repetido). Contudo, isso não significa 
necessariamente "economia de argumentos", pois as críticas ao governo único ficaram subentendidas.

Além disso, podemos considerar que, na concepção política de Heródoto, a oligarquia/aristocracia representa uma forma de governo intermediária entre um modelo com maior concentração de poder e outro que prevê a distribuição. Portanto, a reprodução da fala de Megabizo é minoritária na obra herodotiana porque não corresponderia diretamente ao choque ideológico entre os dois modelos antagônicos expressos na obra herodotiana.

Talvez sob o conjunto da narrativa das Histórias a oligarquia receba um enfoque secundário e particularmente nesse contexto da ascensão de Dario, deve-se notar que Heródoto faz apenas breves alusões à revolta dos magos e não diz nada sobre as insurreições oligárquicas dos países submetidos ao império persa, ao contrário da inscrição de Behistun de Dario. (MENESES SOUSA, 2009: 95)

Entretanto, é fundamental ressaltar que, apesar de curto e de tratar de uma constituição menos importante para o embate ideológico elaborado por Heródoto, o fragmento III.81 é interessante para verificarmos a possibilidade da existência de dois governos de poucos, um bom e outro mau - que são indicados na passagem de forma implícita pelo historiador, mas que demonstram uma dualidade do juízo valorativo. Sem a suposta reprodução da fala de Megabizo tal e qual ela foi descrita nas Histórias, talvez não fosse possível sugerir a presença de seis categorias de governo no pensamento político do historiador durante o debate persa. 


\subsection{O discurso de Dario}

Por fim, após reproduzir os supostos discursos de Otanes e Megabizo, proponentes do governo da maioria e do governo de poucos, respectivamente, Heródoto conta que Dario tomou a palavra em defesa da manutenção da monarquia (III.82). Das três falas presentes no debate persa, essa sem dúvidas é a mais complexa e a mais teórica - além de ser a mais extensa. No fragmento, o historiador esboça não apenas uma teoria acerca do governante único, como sendo um contraponto à democracia, mas nos dá indicativos inclusive para pensarmos em uma evolução das constituições na sociedade, que por sua vez apresenta elementos de uma tradição que posteriormente seria sistematizada inicialmente por Platão, mas, principalmente, por Políbio - que argumenta a respeito do chamado ciclo de constituições ou anaciclose.

Alguns autores, como Roy, ressaltam inicialmente o fato de Heródoto apresentar a defesa de Dario de modo diferente à fala dos outros dois conspiradores (2012: 311). O motivo é que antes de reproduzir os discursos de Otanes e Megabizo, o historiador faz uma espécie de síntese da ideia principal a ser introduzida na sequência. Deste modo, Heródoto afirma que Otanes pleiteou a entrega do poder ao povo (fazendo alusão de que o persa argumentaria em favor da democracia), enquanto Megabizo propôs a criação de um regime oligárquico (muito embora o próprio Megabizo não tenha nomeado seu governo com essa tipologia, conforme vimos na sessão anterior). Em III.82, porém, diz apenas que Dario foi o terceiro a falar, sem usar o mesmo método de introdução ao modelo político a ser teorizado na sequência.

O discurso de Dario representa no debate persa o trecho mais importante para pensarmos na teoria política presente na obra herodotiana. Importante não porque a monarquia se mostra superior às outras formas de governo, mas sim porque a passagem apresenta a maior quantidade de elementos teóricos acerca das constituições, de forma implícita, nos permitindo avaliar as versões negativas dos governos propostas pelos dois rivais de Dario, além de esboçar a ideia do governo monárquico como sendo o mais adequado para a superação do caos - indicando o já mencionado ciclo de constituições. Compreender o discurso do aquemênida é fundamental não apenas para pensarmos no antagonismo dos dois principais modelos políticos apresentados pelo historiador no documento, mas também para consolidarmos a ideia de que Heródoto fala diretamente de três constituições, além de indicar implicitamente a existência de outras três formas de governo. 
A fala de Dario sobre o governante único é reproduzida pelo historiador da seguinte maneira:

Essa foi a opinião apresentada por Megabizo. O terceiro, Dario, expôs sua opinião com os seguintes termos: "Para mim, o que disse Megabizo acerca do regime popular parece ter sido bem dito, mas não no que diz respeito à oligarquia. Dos três regimes oferecidos a nós, teoricamente todos são tão bons quanto possível - a democracia é tão boa quanto possível, a oligarquia da mesma forma, mas o regime monárquico, afirmo que este último é o melhor. Nada pode ser preferível a um governante único, se ele for o melhor dos homens; tendo seus pensamentos na medida, ele pode governar o povo de um modo irrepreensível; e com ele pode-se guardar melhor os segredos que visem ao inimigo. Numa oligarquia, dentre os vários homens aplicam seu talento pelo interesse comum, normalmente nascem inimizades pessoais violentas entre eles; pois cada um quer o líder e fazer com que suas opiniões prevaleçam, e eles acabam odiando fortemente uns aos outros; das inimizades nascem as discórdias, e das discórdias surgem as mortes, e essas mortes levam à monarquia; isso mostra o quanto esse último regime é melhor. Por outro lado, quando é o povo que está no poder, é inevitável que a incompetência surja; e, quando a incompetência se desenvolve na administração dos assuntos públicos, não é a inimizada que nasce entre os incompetentes, mas sim a amizade violente; pois aqueles que colocam o estado no mau caminho o fazem em conluio entre eles. É justamente nesse momento que um homem, tornando-se o protetor do povo, coloca um fim à ação desses homens incompetentes; esse homem, consequentemente, é admirado pelo povo; e, com a admiração, ele é proclamado monarca; esse caso também prova que a monarquia é o melhor regime. E, resumindo tudo em poucas palavras, de onde vem a liberdade? A quem nós devemos essa liberdade? Do povo, da oligarquia ou da monarquia? Portanto, eu sou da opinião, libertados graças a um único homem, nós devemos conservar o governo de um único homem; e, além disso, não devemos extinguir as instituições de nossos antepassados se elas eram sólidas; isso não seria vantajoso." (Hist., III.82)

O discurso de Dario, a exemplo do que ocorre com as falas dos outros dois persas, também pode ser dividido em partes. A primeira é a concordância com o argumento de Megabizo no que diz respeito à crítica contra a democracia, sem nada 
acrescentar, inicialmente, à fala do nobre persa. A segunda, por sua vez, contraria Megabizo ao criticar o governo oligárquico proposto por ele. Há, ainda, uma extensa terceira etapa da fundamentação teórica que apresenta uma comparação entre a monarquia e as outras formas de governo mencionadas anteriormente - na qual Heródoto expõe diversos elementos teóricos essenciais para o pensamento constitucional grego, sem, no entanto, sistematizá-los.

Inicialmente, o aquemênida trabalha com um pressuposto filosófico ao afirmar que cada constituição parece ser a melhor possível para o seu proponente ${ }^{61}$, uma vez que são debatidas na teoria, para em seguida assegurar que o governo único é o mais vantajoso dos três. Contudo, ele próprio faz uma ressalva quase idealista: a de que nada é preferível ao governante único desde que esse governante seja "o melhor dos homens" $^{\text {"62 }}$ (III.82). Essa afirmação pode ser compreendida dentro de uma lógica semelhante à classificação criada posteriormente por Aristóteles, segundo a qual a monarquia é o governo de um só no comando, porém, orientado para o bem comum e, portanto, visando o benefício de toda a comunidade política, e não apenas do governante (ARISTÓTELES, Pol., III.VII.3). Logo, a fala de Dario - a exemplo do pensamento aristotélico -, indica que o monarca deve ter a virtude política necessária para governar o império de modo a atender às necessidades coletivas da população, e não os seus próprios interesses. Esse modelo político se distingue de seu desvio constitucional, a tirania, porque neste caso o governante trabalharia pensando apenas em seu próprio benefício (Pol., III.VII.5), agindo de forma arbitrária e com hýbris, a exemplo do que fazia Cambises, conforme observamos em algumas oportunidades do próprio livro III das Histórias, e na crítica de Otanes à monarquia/tirania.

Portanto, segundo essa concepção, é possível classificar o governo proposto por Dario como sendo uma monarquia, e não uma tirania. Isso indica que a defesa do aquemênida propõe, na realidade, uma constituição diferente daquela criticada por Otanes e Megabizo - que se tratava de um governo tirânico segundo os padrões da tradição política grega. Romilly, em seu artigo clássico, já acenava para o fato do debate

\footnotetext{
${ }^{61}$ Segundo Meneses Sousa, esse é um aspecto importante porque o discurso se vale da expressão tôi logôi $i$, que significaria "nas palavras", ou "em tese". Isso implica pensarmos que o aquemênida indica que cada forma de governo defendida pelos nobres parece ser a mais apropriada, quando analisadas apenas de modo teórico. Seria, portanto, uma maneira teórica de identificar aspectos positivos em cada modelo constitucional. Após afirmar isso, o discurso utiliza argumentos para defender a superioridade da monarquia ante as demais. A diferença entre teoria e prática está presente da tradição política grega, inclusive nas obras de Platão e Aristóteles (2009: 96).

${ }^{62}$ Grifo nosso.
} 
persa apresentar aos leitores a defesa ao governo monárquico e a crítica ao tirânico (ROMILLY, 1959: 84) - indicando, no entanto, que ambas as constituições possuem a mesma característica de centralização de poder, porém, com exercícios e interesses divergentes. Bobbio, posteriormente, chegaria à mesma conclusão: a de que existe uma elaboração de argumentos positivos e negativos no fragmento, indicando uma “classificação completa, que será enunciada por sucessivos pensadores, para quem elas (as constituições) não serão apenas três, porém seis - já que as três boas correspondem três outras, más" (BOBBIO, 1985: 41).

Como vimos na sessão anterior deste capítulo, a reprodução do discurso de Megabizo nos leva a verificar que o persa não propõe uma oligarquia, mas sim uma aristocracia - inclusive porque ele não menciona o governo oligárquico. Entretanto, como argumenta Sealey (1973: 273-274), o crítico desse modelo - no caso Dario menciona diretamente a constituição oligárquica em seu comentário contrário à proposta de Megabizo. Esse fragmento das Histórias é interessante porque Heródoto descreve o governo de poucos como causador de divergências entre indivíduos e grupos, resultando, no fim, na criação de facções cujo principal objetivo seria a disputa interna pelo poder - e não o benefício da comunidade política. Isso fica claro quando Dario afirma que numa oligarquia as inimizades surgem porque cada indivíduo do seleto grupo quer fazer com que suas opiniões prevaleceçam, resultando em ódio e derramamento de sangue (III.82).

Portanto, segundo essa concepção, a constituição atacada por Dario não instituiria um governo formado pelos melhores e orientado para o bem comum, conforme propôs anteriormente por Megabizo, que seguiria a definição do governo legítimo sistematizado por Aristóteles em sua Política e tipificado como uma aristocracia.

Nesse ponto, é interessante pensarmos que o argumento de Dario trabalha com a ideia de stásis, ou seja, guerra civil (MENESES SOUSA, 2009: 99; ROY, 2012: 321). O termo indica que, na concepção política do autor, o conflito ideológico entre os grupos resultaria em choques violentos, que segundo Heródoto terminariam em derramamento de sangue dentro da própria pólis, por conta da oposição entre as facções. É nesse aspecto que surge o primeiro indicativo de uma transformação constitucional, uma vez que, de acordo com o autor, essa violência entre as facções resultaria no surgimento de um governante único - capaz de colocar fim à stásis, ao caos, para levar ordem e paz à sociedade. Ou seja, a oligarquia geraria uma situação insustentável de guerra civil, 
causada pela hýbris dos próprios componentes desse tipo de governo. Desses excessos emergiria o caos, e o governo monárquico surgiria naturalmente a partir desse cenário e seria considerado o único capaz de levar o ordenamento à pólis. Logo, a constituição passaria por um processo de transformação.

Em primeiro lugar, é preciso lembrar que Heródoto relata situações semelhantes nas narrativas de ascensão de Deioces, na Média, e de Pisístrato, em Atenas: uma série de conflitos conduziu a sociedade à desordem, que só pode ser superada a partir do estabelecimento de um governante único no controle político da cidade. Há, portanto, um paralelismo envolvendo a história desses dois monarcas/tiranos com a teoria elaborada por Dario.

Pensando nesse ponto, Heródoto narra a ascensão de Deioces no livro I das Histórias em um contexto que remete à libertação da Média (até então sob domínio assírio) e à unificação do seu território - compondo, portanto, um estado dotado de território unificado, população e governo (DALLARI, 1995: 61). Heródoto nos conta que Deioces não chegou à tirania de forma casual, mas sim a partir de uma estratégia que envolvia a forma como o medo se apresentava à população. Segundo o historiador, Deioces se dedicou à prática da justiça de forma zelosa "numa época em que havia muita injustiça em toda a Média" (Hist., I.96). Isso remete à ideia de que o tirano nas Histórias, de acordo com alguns autores, desempenha a função de investigar os fatos, buscar informações e usar o conhecimento de forma sábia, para posteriormente tomar as decisões mais corretas (CHRIST, 1994: 167). É uma forma de considerar o tirano como uma espécie de administrador da justiça na sociedade.

A atuação de Deioces na resolução das contendas fez com que ele fosse considerado um grande juiz, por conta da assertividade nos julgamentos emitidos (I.96). Conforme o número de pessoas que o procuravam crescia e sua importância para a manutenção da ordem aumentava, o medo decidiu não mais emitir julgamentos, supostamente por conta do tempo demandado para o desempenho de tal tarefa. Diante disso, a sociedade retornou ao caos (I.97), que só foi superado posteriormente com a “coroação de Deioces como rei dos medos" (I.98).

A lógica que opera por trás da história de Deioces é, praticamente, um conto de superação do caos por meio da ascensão da monarquia - o fím da stásis a partir do estabelecimento de uma monarquia/tirania. É uma situação semelhante à de Pisístrato, que vivia em uma Atenas imersa na luta entre facções oligárquicas, que gerava instabilidade política e social. Diante disso, um indivíduo ocupou a acrópole e se 
transformou em um governante único, com o objetivo de levar ordem à pólis (Hist., I.59). De acordo com o documento, para conquistar o apoio da população - e assim conseguir se manter no cargo - Pisístrato adotou uma série de medidas populares, fato que o fez ser considerado por filósofos posteriores como sendo um tirano moderado cujo apoio vinha das classes populares devido ao fato de governar de acordo com as leis (ARISTÓTELES, Const. Atenas, 16).

Seguindo esse entendimento, democracia e oligarquia seriam regimes políticos que culminam fatalmente em guerra civil, e a monarquia nasce nesse contexto de anomia para superar o caos e restaurar a ordem. A ascensão de Dario, portanto, entra como mais um elemento que comprova essa ideia na obra herodotiana. O aquemênida, nas Histórias, é o responsável por colocar fim ao governo ilegítimo de Smérdis, que desencadeou inclusive num evento de violência, o massacre dos magos (narrado por Heródoto pouco antes do debate persa, em III.78-79). Embora tenha sido escrita com um propósito diferente do texto herodotiano, a própria Inscrição de Behistun retrata Dario como um líder capaz não apenas de restaurar a dinastia, mas também de conter as inúmeras insurgências comandadas pelos líderes descritos na epígrafe, como Fravartis, Martiya, Frada, além de todos os outros que se levantaram contra o governante e foram derrotados em combate durante o primeiro ano da gestão do aquemênida (as rebeliões são descritas em Behistun a partir do parágrafo 16).

Flory já indicava essa semelhança nas histórias de Deioces, Pisístrato e Dario, argumentando que reside aí não apenas a ideia da solução para a instabilidade social ou para a ilegitimidade do governante, mas principalmente para a elaboração de um conexo padrão de pensamento político herodotiano, que nesses casos associa a monarquia/tirania com o estabelecimento da ordem (1987: 120) - muito embora em vários trechos da narrativa o próprio Heródoto denuncia os excessos cometidos pelos governantes únicos, como Cambises, por exemplo.

Um segundo ponto a ser considerado é a evolução política proposta implicitamente por Heródoto no discurso de Dario. Ao afirmar que do caos causado pela luta entre as facções emerge a necessidade de um governante único - que usa sua métis para controlar a situação - o historiador indica que as constituições não são permanentes e monolíticas, podendo se transformar de acordo com a própria dinâmica política da sociedade - e de acordo com as necessidades da comunidade política. Esse princípio não é discutido de forma sistemática por Heródoto, mas sugere implicitamente que já 
era um argumento minimamente conhecido ou discutido pelos pensadores gregos do período. As Histórias, nesse sentido, apenas discutem a questão de forma pouco aprofundada. A teoria, posteriormente, seria de fato sistematizada por outros autores, como Platão e Políbio, sobretudo. A ideia é que haveria uma espécie de ciclo natural entre as formas de governo, conduzindo o estado a sofrer transformações políticas. Isso faria com que houvesse uma transição de uma constituição para outra - como, para Heródoto, a passagem "natural" da oligarquia para a monarquia como única forma de superação do caos.

De acordo com essa ideia, uma pólis que vive sob uma constituição monárquica pode passar por um processo de abertura política e o governante único ser substituído por um grupo, considerado mais apto para governar a cidade. Este seria um movimento de descentralização. Entretanto, esse governo dos melhores pode se degenerar, dando lugar a uma oligarquia lastreada pela preocupação com os interesses dos cidadãos mais ricos - cujo propósito poderia ser, por exemplo, a manutenção dos privilégios. Ou seja, o governo de poucos, nesse caso, possui dois modelos distintos, um bom e outro ruim. Posteriormente, o caos resultante dessa forma de governo levaria a uma nova etapa da distribuição de poder, que permitiria ao povo tomar o controle político da comunidade, num regime democrático. Porém, essa democracia também começaria a apresentar falhas, quando as massas passassem a governar sem se preocupar com o bem comum, configurando uma oclocracia: a constituição mais parecida com o modelo criticado por Megabizo em III.81. Quando, por fim, a situação chegasse a um ponto incontrolável, seria natural que um único indivíduo, dotado de capacidades políticas notáveis, fosse escolhido para levar ordem à pólis, retomando, assim, o governo monárquico. Esse conjunto de transformações políticas configura o ciclo de constituições - pois os regimes políticos se sucedem uns aos outros, de acordo com as dinâmicas da própria sociedade, constituindo um ciclo que culmina na repetição dos modelos (BOBBIO, 1985: 66). Esse é o princípio da anaciclose, segundo o qual há um inevitável ciclo de constituições (BRINK \& WALBANK, 1954: 108).

Essa ciclo, no limite, pode ser interpretado como uma forma de reorganização das forças políticas dentro do Estado, que resulta em um constante embate entre as classes sociais e os atores políticos, gerando uma tensão entre caos e ordem: ora a preocupação egoísta (de grupos ou governante) prevalece; ora o bem da comunidade política é posto como prioridade. 
O fato de Heródoto sugerir, por intermédio da fala de Dario, que o choque oligárquico leva à ascensão do governo monárquico indica essa reorganização das forças políticas no sentido de reordenar a sociedade. Nesse caso, o governante único estabeleceria a ordem a partir de uma monarquia (governo proposto pelo aquemênida), e não da tirania (o governo criticado por Otanes e Megabizo por conta de seus excessos, em III.80-81).

Ao mencionar o governo popular, o historiador constrói o mesmo tipo de entendimento de transformação constitucional. A fala de Dario indica que o poder conferido ao povo levaria inevitavelmente à incompetência na gestão do Estado, e que, além disso, geraria conflitos (stásis), cuja solução dependeria da ascensão de um governante único ao poder, admirado pelo povo e dotado de métis para dar fim à crise. Essa menção ao monarca admirado pode ser uma alusão a Pisístrato e Deioces. O problema seria, portanto, a hýbris do governo do povo, uma crítica que Megabizo já havia feito em seu próprio discurso (MENESES SOUSA, 2009: 95-96).

No caso dessas duas transformações sugeridas por Dario - referentes à oligarquia e à oclocracia, o ciclo esboçado estaria provavelmente em um estágio final: no qual as constituições degeneradas seriam substituídas pelo retorno do monarca à administração do estado, que poderia dar início a um novo ciclo (que não é mencionado na fala do aquemênida).

Esse entendimento de que as constituições se transformam não é exclusivo do pensamento herodotiano, conforme já mencionado. Tempos depois de Heródoto, a filosofia de Platão trataria do assunto. O autor dedica o oitavo livro de A República para discorrer a respeito das formas de governo. De acordo com a análise do filósofo, existem a princípio quatro formas de governo, que podem ser consideradas inferiores ou degeneradas, narradas no diálogo a seguir - que indica o processo de passagem entre um modelo e outro:

\footnotetext{
- "De minha parte", disse ele, "estou realmente ansioso para aprender quais são os quatro governos que você falou".

- "É fácil, digo, satisfazê-lo, porque os governos que menciono têm nomes bem conhecidos aqui. A primeira (forma de governo), e a mais elogiada por muitos,
} 
é o famoso governo de Creta e da Lacedemônia ${ }^{63}$; a segunda, em ordem de classificação e mérito, é chamada oligarquia: é um governo cheio de incontáveis defeitos; vem em seguida um governo que se opõe ao precedente, a democracia; e finalmente a nobre tirania, que supera todas as outras. É a quarta e última doença do Estado". (PLATÃO, Rep., VIII, 544 c)

O diálogo remete à ideia de que Platão considerava a existência de uma espécie de degeneração das formas de governo, classificando-as a partir de um ordenamento das quatro constituições existentes, elencadas da melhor para a pior: timocracia, oligarquia, democracia e tirania. Há, portanto, uma ideia de transformação natural, conforme já havia sido sugerido implicitamente por Heródoto.

A primeira constituição é o governo baseado na honra, ou seja, a timocracia, que é apresentada a nós por Platão - uma vez que ele é o primeiro a incluir esse modelo em uma relação de tipologias. Bobbio (1985: 47) ressalta que a filosofia platônica considerava Esparta como um estado elogiável, embora tivesse uma falha inerente: o fato de honrar o guerreiro mais do que os sábios. A segunda forma de governo mencionada por Platão seria a oligarquia, um governo formado por poucos e já presente na obra de Heródoto. A democracia seria uma versão de governo da maioria, mas inferior à constituição que a antecede, ou seja, o modelo oligárquico. Por fim, o autor menciona a tirania, ironicamente descrita com o uso do adjetivo "nobre", justamente por ser considerado o pior regime possível.

Em uma passagem pouco posterior do documento, Platão indica a possibilidade de existência de uma quinta forma de governo - que seria, segundo essa concepção, um modelo anterior à timocracia e ideal, sendo assim, a melhor das constituições.

- "Eu digo, este governo (timocracia) não sugere um meio termo entre a aristocracia e a oligarquia?"

- "Sim, seguramente.” (PLATÃO, Rep., VIII, 547 c)

Segundo Bobbio (1985: 47), Platão trabalha com a ideia de que existem quatro constituições reais, que são corrompidas e, portanto, inferiores: timocracia, oligarquia, democracia e tirania; além delas, existiria uma quinta forma de governo, a aristocracia, o único modelo perfeito e, logo, superior. É preciso lembrar que Platão escreveu suas

\footnotetext{
${ }^{63}$ Platão se refere à timocracia, o governo baseado na honra.
} 
obras em um período posterior a Heródoto, tendo presenciado uma época de desencanto justamente por ver Atenas se degenerar após a Guerra do Peloponeso. Isso, talvez, explique a visão mais pessimista sobre os modelos constitucionais.

O mais importante, do ponto de vista da filosofia política, é que identificamos na obra de Platão um movimento de transformação entre as constituições semelhante ao elaborado por Dario, na passagem III.82 das Histórias. Entretanto, o aquemênida, de certa forma, indica uma solução para a stásis, que é a transição dos governos degenerados (oligarquia e oclocracia) para uma monarquia. Platão, entretanto, não explica o que acontece quando a pólis conclui o ciclo de mudanças, ou seja, não indica se haveria um retorno para a primeira constituição - ou, talvez, a elevação para uma aristocracia. A obra platônica, portanto, não indica a repetição do ciclo.

De qualquer forma, o pensamento político herodotiano, expresso a partir da fala de Dario, parece indicar para o mesmo tipo de elaboração teórica que Platão faria posteriormente. Essa ideia de anaciclose seria retomada posteriormente por Políbio, que de fato sistematizou o conceito de forma mais acabada, no século II a.C.. Segundo o autor, uma constituição inevitavelmente vai suceder a outra, até retornar à forma de governo inicial, partindo da monarquia, enfrentando várias transformações que oscilam entre bons e maus governos (BRINK \& WALBANK, 1954: 108), até adotar novamente uma constituição monárquica - ou seja, é um modelo mais elaborado do que o presente na passagem III.82 das Histórias, ao mesmo tempo em que indica o retorno à constituição inicial - algo que Platão não fez.

Políbio apresenta sua teoria dos ciclos da seguinte maneira:

A monarquia muda primeiro para seu vício associado, a tirania; depois, a supressão dos dois dá luz à aristocracia. A aristocracia por sua vez degenera para uma oligarquia; e quando o povo, inflamado pela ira, busca vingança sobre o governo por suas regras injustas, surge a democracia; e no devido tempo a liberalidade e a ilegalidade desta forma de governo produzem o governo da multidão (oclocracia) para completar a série. (POLÍBIO, Hist., VI, II, 4)

Bobbio resume o funcionamento da anaciclose para Políbio:

(...) o processo histórico desenvolve, ciclo por ciclo, uma tendência que é, em última análise, degenerativa, como a descrita por Platão; contudo, 
diferentemente do ciclo platônico, em que cada forma é uma degeneração da precedente, num processo contínuo, o ciclo polibiano se desenvolve através da alternância de constituições boas e más (...). Em outras palavras, a linha decrescente do ciclo platônico é contínua, a do ciclo polibiano é fragmentada por uma alternância de momentos bons e maus, embora tenda para baixo. (BOBBIO, 1985, p. 67).

Ainda que as transformações sugeridas pela fala de Dario sejam incompletas e não demonstrem o mesmo grau de sofisticação teórica das degenerações constitucionais propostas por Platão e, principalmente, por Políbio, é possível supor que o pensamento herodotiano legou uma importante contribuição para as gerações posteriores - que evidentemente foi desenvolvida e trabalhada de um modo distinto.

Esses exemplos, extraídos das obras de Platão e Políbio, indicam que havia uma tradição política sobre as formas de governo em constante elaboração em território grego, a partir do século VI a.C.. Píndaro pode ter sido o primeiro a esboçá-la, indicando a distinção numérica entre os governos de um, de poucos e da maioria, porém, coube a Heródoto formalizar em seu documento a existência de tipologias específicas para os modelos constitucionais mais tradicionais. Posteriormente, outros autores se encarregariam da tarefa de ampliar a discussão, indicando, por exemplo, as transformações constitucionais (Platão), a sistematização das formas justas e degeneradas, tornando clara a preocupação com os usos do poder (Aristóteles), e o detalhamento da teoria da anaciclose (Políbio) ${ }^{64}$.

É, portanto, uma tradição de pensamento político que pode ter suas origems nas discussões da ágora, mas dependeu de Heródoto - e da fala dos persas - para ter um princípio teórico balizador.

Vimos, nesta sessão do capítulo, que a fala de Dario é a que apresenta o maior grau de complexidade a respeito da compreensão das formas de governo, inicialmente por nos permitir a interpretação da existência de três regimes distintos, dois degenerados (oclocracia e oligarquia) e um positivo (monarquia), mas também pela indicação embrionária de uma espécie de transformação natural das constituições. Esses

\footnotetext{
${ }^{64}$ Outras obras da filosofia clássica também abordam as formas de governo. Aristóteles debate a questão não apenas n'a Política, mas também em Ética a Nicômaco; Platão, por sua vez, dedica partes da obra Leis ao debate das constituições.
} 
elementos reforçam a ideia de que é o discurso do aquemênida é mais teórico do debate persa.

Ainda assim, alguns especialistas defendem que o argumento de Otanes foi o mais bem construído, pois faz um profundo ataque à tirania, inclusive valendo-se de exemplos recentes da história persa, o que dá um caráter mais histórico e menos filosófico para a fala. Esse discurso, segundo essa concepção, foi respondido de modo considerado frágil por Dario (LATEINER, 1989: 169; MENESES SOUSA, 2009: 101102), cuja argumentação depende exclusivamente do uso de conjecturas teóricas. De qualquer forma, é preciso considerar que a crítica de Otanes é mais apropriada às experiências tirânicas gregas do que aos governantes persas. 


\subsection{As seis formas de governo}

No decorrer deste terceiro capítulo, trabalhamos com a análise específica de cada um dos três discursos supostamente pronunciados pelos persas após o chamado interregno de cinco dias entre o massacre dos magos e o debate entre Otanes, Dario e Megabizo. Conforme já discutimos nesta dissertação, analisar o fragmento III.80-82 das Histórias por uma perspectiva da teoria política nos leva a compreendê-lo de forma distinta dos estudos cuja preocupação residia na busca pela verdade histórica do fragmento e na análise da estrutura literária do documento - a ideia era justamente superar o fato histórico e a influência sofística no texto herodotiano. A análise política permite, desta forma, uma interpretação do fragmento a partir da leitura da construção de um pensamento político na obra de Heródoto, que esboça de modo não-sistemático a teoria das formas de governo - algo sofisticado e que, em nossa análise, influenciaria filósofos como Platão e Aristóteles.

Vimos, nas três sessões anteriores deste capítulo, que o historiador utiliza a suposta fala dos nobres persas para indicar argumentos acerca do governante único, do governo de poucos e do governo da maioria, naquilo que diversos autores consideram como sendo o marco fundador da teoria das formas de governo (BOBBIO, 1985: 39; BUTTI DE LIMA, 2009: 4), sobretudo por apresentar a tripla classificação dos regimes políticos, tipificando devidamente as três constituições consideradas tradicionais para o período.

Duas coisas ficam claras na leitura do debate persa. A primeira é que o texto não se refere a uma realidade persa - uma vez que as experiências indicadas pelos nobres possuem semelhanças com a realidade política grega, e não com a oriental. Além disso, Heródoto parece tratar como um thôma alguns dos argumentos apresentados pelos três conspiradores. Talvez a principal "maravilha" enunciada pelo outro nesse fragmento seja a defesa da democracia por Otanes - uma vez que a passagem acaba chegando ao público helênico com um estranhamento reconhecido pelo próprio historiador (em III.80), por se tratar de um regime político pouco comum à Pérsia, de acordo com a visão grega do período sobre o oriente (SÁNCHEZ, 2009: 69).

Porém, a leitura dos três discursos nos aponta para uma discussão política mais abrangente do que o simples fato deles parecerem ou não estranhos à realidade persa. Importa, para nós, os complexos modelos políticos construídos por Heródoto nessa passagem, que pode ser considerada uma espécie de etapa final do embate entre 
democracia e monarquia elaborado pelo autor em um contexto mais amplo ao longo do documento, e que constrói as bases para um importante desdobramento: a presença de dois juízos valorativos distintos para cada constituição apresentada.

Conforme Bobbio nos indica, um dos pontos mais notáveis do fragmento é o fato de que

“cada um dos três persas faz uma avaliação positiva de uma das três constituições e anuncia um julgamento negativo das outras duas. Defensor do governo do povo (que ainda não é chamado de "democracia"; esse termo tem de modo geral, nos grandes pensadores políticos, uma acepção negativa, de mau governo $^{65}$ ), Otanes condena a monarquia. Defensor da aristocracia, Megabizo condena o governo de um só e o governo do povo. Por fim, Dario, que defende a monarquia, condena tanto o governo do povo como o governo de uns poucos (usando o termo destinado a descrever ordinariamente a forma negativa do governo de poucos - a oligarquia). (BOBBIO, 1985: 41)

Para simplificar a sua interpretação para essa relação entre as teorias positiva e negativa acerca do debate persa, Bobbio elaborou o seguinte quadro, que reproduzimos com algumas adaptações, para facilitar a compreensão:

Quadro 2: Teoria positiva e teoria negativa

\begin{tabular}{lccc}
\hline & Governo de um & Governo de poucos & Governo da maioria \\
\hline Otanes & Aspecto negativo & - & Aspecto positivo \\
Megabizo & Aspecto negativo & Aspecto positivo & Aspecto negativo \\
Dario & Aspecto positivo & Aspecto negativo & Aspecto negativo \\
\hline
\end{tabular}

Fonte: BOBBIO, Norberto. A teoria das formas de governo. Brasília: editora UnB, 1985, $4^{\mathrm{a}}$ edição, p. 41 (com adaptações).

Esse tipo de análise - associada à tradição acerca da teoria das formas de governo da filosofia política posterior a Heródoto - nos ajuda a sustentar a ideia de que há, nesse fragmento das Histórias, uma demonstração do funcionamento de seis modelos constitucionais, seguindo a lógica de argumentação atribuída pelo autor a cada

\footnotetext{
${ }^{65}$ Provavelmente, a principal referência de Bobbio ao fazer essa afirmação é Aristóteles e sua visão negativa da democracia, expressa no terceiro livro da Política.
} 
um dos três persas. Procuramos demonstrar esses aspectos positivos e negativos no decorrer deste capítulo.

A leitura das teorias positiva e negativa (ou dos juízos valorativos) deriva, por sua vez, do cruzamento de dois critérios distintos, mas complementares. Ambos contribuem para pensarmos na forma como o poder é dividido e, ainda, na ideologia que norteia o uso do poder pelo governante hegemônico (ROY, 2012: 300). O primeiro critério seria analisar o regime de governo buscando responder a seguinte pergunta: "quem governa o Estado a partir desse modelo constitucional"? Ou seja, é um modo de identificar quem ocupa os cargos de governo: se um indivíduo, um grupo de pessoas, ou a maioria da população com o título de cidadania. Em seguida, é preciso analisar como o poder é exercido, respondendo a questão: “como o governante governa?" Aqui, o objetivo é identificar como o governante usa o poder.

Desta forma, é possível pensarmos no seguinte esquema, que indica a tipologia a partir do cruzamento das duas variáveis apresentadas no parágrafo anterior:

Quadro 3: Posse e uso do poder

\begin{tabular}{llcc}
\hline & & \multicolumn{2}{c}{ Como governa? } \\
\cline { 3 - 4 } & & Bem & Mal \\
\cline { 3 - 4 } Quem governa? & Governo de um & Monarquia & Tirania \\
& Governo de poucos & Aristocracia & Oligarquia \\
& Governo da maioria & Democracia & Oclocracia \\
\hline
\end{tabular}

Fonte: BOBBIO, Norberto. A teoria das formas de governo. Brasília: editora UnB, 1985, $4^{\text {a }}$ edição, p. 42 (com adaptações).

Se substituirmos o elemento numérico da pergunta "quem governa" pelo nome dos persas que emitiram suas opiniões no debate, teremos o seguinte arranjo, tomando como base o que cada um propôs (indicando os elementos positivos) e o que atacou (indicando os elementos negativos dessa constituição):

Quadro 4: As formas de governo no debate persa

\begin{tabular}{lccc}
\hline & Otanes & Megabizo & Dario \\
\hline Democracia & $\mathrm{X}$ & & \\
Oclocracia & & $\mathrm{X}$ & $\mathrm{X}$ \\
Aristocracia & & $\mathrm{X}$ & \\
\hline
\end{tabular}




\begin{tabular}{lccc}
\hline Oligarquia & & $\mathrm{X}^{66}$ & $\mathrm{X}$ \\
Monarquia & & $\mathrm{X}$ \\
Tirania & $\mathrm{X}$ & $\mathrm{X}$ & \\
\hline
\end{tabular}

Fonte: elaboração do autor

Essa perspectiva nos revela a elaboração de um pensamento político bastante sofisticado, que busca formas de encontrar pontos positivos e negativos para as constituições propostas por Otanes, Megabizo e Dario. Porém, precisamos lembrar que, segundo Murari Pires (2012: 183), o debate persa fala grego e, portanto, não foi escrito com o objetivo de dialogar com uma realidade comum à Pérsia. $\mathrm{O}$ autor, provavelmente, inseriu essa passagem nas Histórias para discutir exclusivamente a política das póleis inclusive porque o próprio historiador utiliza os termos clássicos consagrados em território grego, e não persa, e certamente estava inserido num contexto no qual os próprios helenos discutiam a respeito da melhor constituição possível para uma cidadeestado. Além disso, é possível pensarmos que a inclusão dessa passagem no livro III não altera em nada a cronologia política da Pérsia, pois Dario assumiu o trono após a deposição dos magos - da mesma forma como ele próprio descreveu na Inscrição de Behistun. Se houve ou não um debate entre a morte de Smérdis e a coroação de Dario, não importa.

Pela análise dos discursos - e do contexto do debate persa - é possível interpretar que o antagonismo entre o governo de um e o governo da maioria tenha sido expresso a partir de dois focos de análises distintos. O primeiro é a comparação entre a democracia (seguindo um modelo ateniense) e a tirania (cujo principal referencial do autor seria o tirano Pisístrato e os excessos cometidos por Cambises, conforme discutimos no segundo capítulo). Nesse sentido, a teoria política nos ajuda a compreender que, pela visão de Heródoto, os valores democráticos se mostram superiores aos tirânicos, por ressaltarem elementos como a liberdade ante a servidão, a igualdade ante a opressão, e a emancipação ante a centralização - todos esses são argumentos ideológicos presentes em pontos do livro $\mathrm{V}$, como, por exemplo, no parágrafo 78. Também podemos interpretar esses elementos a partir dos termos

\footnotetext{
${ }^{66}$ Heródoto, como narrador, atribui a forma de governo proposta por Megabizo como sendo uma oligarquia. Contudo, em seu próprio discurso (segundo a reprodução do historiador), trata-se de uma aristocracia.
} 
empregados por Sara Forsdyke, ou seja, o embate ideológico entre a resistência e a fraqueza cívica.

Contudo, esse antagonismo presente no debate persa também pode ser compreendido a partir de um segundo foco, que nos permite uma leitura menos monolítica - demonstrando o quanto o pensamento constitucional herodotiano é sofisticado. Como o autor deixa implícito o fato de que as formas de governo possuem duas versões, se olharmos para o governo de um como sendo uma monarquia (pelo modelo defendido por Dario) e o governo de muitos como uma oclocracia (baseada na ideia exposta por Dario e Megabizo) podemos concluir que, dependendo de uma série de condições e circunstâncias, mesmo o governante único pode governar bem, ao mesmo tempo em que o povo pode governar mal. Tudo depende, portanto, não apenas da distribuição de poder, mas sim do uso desse poder por parte do indivíduo (ou indivíduos) no governo.

Esse movimento indica, por suposição, que Heródoto pode ter feito uma ponderação sobre as opiniões mais radicais quanto às formas de governo - considerando que existem possibilidades distintas e complexas para o uso do poder.

Esse argumento permite, inclusive, pensar no ciclo de constituições: se existe espaço no documento herodotiano para interpretarmos essa ponderação, pode-se pensar que o autor também vislumbrava a possibilidade de que as constituições sucedessem umas as outras, a partir das contingências de cada época, até se repetirem. Assim, a fala de Dario nos indica que o historiador reconhecia a existência de uma dinâmica social e política que levava às constantes transformações. Entretanto, conforme já dissemos em diversas ocasiões neste estudo, a opinião de Heródoto não é sistematizada. Nesse ponto, devemos pensar que a anaciclose herodotiana apenas sugere esse movimento por meio do terceiro discurso persa, mas não há nenhum tipo de afirmação conclusiva para o ciclo em si - conforme fariam de modo mais enfático Platão e Políbio posteriormente, em $A$ República e Histórias, respectivamente.

Essa teoria faz sentido se pensarmos principalmente que há na fala de Dario uma defesa da monarquia como constituição responsável pela superação da stásis, causada pelo governo popular - argumento que remete a Políbio, para quem a oclocracia corresponde à última etapa do ciclo, quando a hýbris da multidão leva à ausência de leis. E, a partir disso, o ciclo se inicia novamente.

Diante disso, é possível pensarmos que Heródoto não apenas elaborou um pensamento constitucional no debate persa, como também indicou a existência de seis 
formas de governo, e não somente de três - como uma leitura inicial poderia indicar. Heródoto, porém, não sistematizou a discussão e, assim, não temos uma indicação clara sobre a presença de governos bons e maus - inclusive porque as tipologias eram muito fluidas no século V a.C..

Entretanto, um elemento que dá base para essa ideia é o fato de que, posteriormente, autores como Platão, Aristóteles e Políbio argumentaram em defesa das constituições justas e dos seus respectivos desvios, cada um com suas particularidades teóricas, mas todos provavelmente baseados na mesma tradição.

Nesse capítulo, portanto, analisamos inicialmente o debate geral das teorias constitucionais, indicando que ela sempre prevê duas análises: prescrição e descrição. Posteriormente, partimos para uma interpretação isolada de cada um dos três discursos, de modo a verificar como as falas de Otanes, Megabizo e Dario ajudam a construir uma compreensão dupla acerca das formas de governo. Isso nos permitiu constatar que Heródoto, na realidade, indica a existência de seis formas de governo, e não apenas três, além de apresentar a ideia embrionária da teoria da anaciclose. 


\section{Considerações finais}

O objetivo deste estudo foi investigar o chamado debate constitucional persa, narrado por Heródoto nos capítulos III.80-82 das Histórias. A ideia era propor uma leitura do fragmento com o suporte da filosofia política, de modo a analisar o juízo valorativo herodotiano no que diz respeito às constituições e, além disso, verificar que o autor se revela um pensador político sofisticado, que usa o suposto discurso de três persas para consolidar sua lógica a respeito dos governos de um, de poucos e da maioria - teoria que só seria sistematizada posteriormente, por meio da filosofia de Platão, Aristóteles e Políbio, dentre outros.

Essa passagem do documento suscitou uma grande quantidade de estudos, por parte de diversos pesquisadores, no sentido de encontrar um modo de explicar o “estranho" debate entre Otanes, Megabizo e Dario. Nesse sentido, havia os especialistas que defendiam que Heródoto deliberadamente inventou o fragmento, pois não era possível encontrar nenhuma outra evidência documental a respeito dele - negando, portanto, a verdade histórica. Outros, por sua vez, buscavam evidências para comprovar minimamente a possibilidade de que três persas pudessem, realmente, ter deliberado acerca da melhor forma de governo, mesmo que Heródoto tenha helenizado a discussão para facilitar a compreensão para o público grego.

Seguindo outra perspectiva, alguns autores tentavam analisar a estrutura textual do debate persa para encontrar influências da sofística grega na passagem, sobretudo argumentos comuns a Protágoras.

Contudo, analisar o fragmento a partir dessas perspectivas ignora outra possibilidade bastante promissora, que procura superar a preocupação positivista para se dedicar ao estudo da teoria política prenunciada por Heródoto nessa curta, mas importante passagem das Histórias. Desse modo, optamos por buscar uma forma de verificar se existe um pensamento constitucionalista na obra do historiador de Halicarnasso: investigando o modo como ele constrói os juízos valorativos acerca do governante único, do governo de poucos e do governo da maioria - que, no fim, resultaria no grande embate ideológico descrito no debate persa.

Para cumprir esse objetivo, inicialmente apresentamos em Heródoto e a escrita das Histórias uma revisão bibliográfica sobre o autor, como ponto de partida para compreendermos quem foi o historiador e qual sua relação pessoal com a tirania - um 
dos modelos políticos antagônicos de sua obra. Nessa mesma etapa do trabalho, repassamos alguns dos principais trabalhos acerca do debate persa, que podem ser agrupados em duas correntes de análise bastante recorrentes: a) pesquisas preocupadas com o fato histórico em si e b) pesquisas sobre a estrutura literária do fragmento. Diante disso, são apresentadas ao leitor as duas principais linhas de pesquisa sobre o tema, de modo, em seguida, a indicar qual é a contribuição do nosso estudo para a compreensão da passagem, ou seja, a análise por meio da filosofia política - que permite sustentar a hipótese de que há sim, em Heródoto, a construção de um pensamento constitucionalista.

Para demonstrar que existe um contraponto ideológico entre monarquia e democracia, foi necessário fazer uma análise desses dois modelos políticos antagônicos em $O$ pensamento político nas Histórias. Para demonstrar esse antagonismo, buscamos apresentar argumentos que demonstram como o historiador constrói um juízo valorativo negativo acerca da tirania nos antecedentes do debate persa, especificamente no livro III das Histórias - sobretudo a partir da construção dos arquétipos de Cambises e Smérdis, retratados como um rei louco e sacrílego, e um usurpador, respectivamente. Em contrapartida, mostramos como o autor constrói um juízo valorativo positivo acerca da democracia ateniense, que se contrapõe à tirania de Pisístrato. Além disso, no mesmo capítulo fizemos uma breve análise da aristocracia na obra, dentro do mesmo contexto de Atenas - mostrando que ela ocupa um papel intermediário entre a centralização e a distribuição de poder.

A conclusão, até essa etapa, é que a leitura do debate persa dentro do seu contexto revela, de fato, um autor preocupado em construir um modelo político que dialogasse com o público grego, sobretudo ateniense, e que retratasse o governo de um de modo negativo e o governo da maioria de modo positivo. O motivo é que, por essa reflexão, constatamos que a oposição entre as constituições passa pela questão da construção da identidade ateniense, em contraposição com uma identidade estrangeira. Nesse caso, podemos dizer que Heródoto retrata o regime político grego como sendo libertador, enquanto o persa como opressor.

Contudo, ainda era necessário analisar separadamente cada um dos três discursos supostamente pronunciados pelos persas em III.80-82, e isso foi feito em A teoria sobre $o$ debate persa. Essa etapa da pesquisa nos levou a concluir que, embora Heródoto tenha construído juízos valorativos específicos para os modelos antagônicos (negativo para a tirania e positivo para a democracia), é possível perceber que há elementos 
implícitos indicando para uma elaboração política mais complexa, que não é tão binária como parecia inicialmente - e que, além disso, demonstra uma grande sofisticação nãosistematizada, mas que ao mesmo tempo evoca uma questão possivelmente comum em sua época. Essa elaboração complexa reside no fato de Heródoto classificar cada forma de governo a partir de dois aspectos, um positivo e outro negativo, resultando, portanto, em seis modelos constitucionais.

Após a superação dessas três etapas de nossa investigação, é possível partirmos efetivamente para as nossas considerações finais. Constatamos que Heródoto constrói sua teoria sobre as formas de governo em dois momentos distintos, de acordo com a nossa leitura. O primeiro momento pode ser constatado quando o autor esboça um juízo valorativo nos antecedentes do debate persa, acerca da tirania, e no contexto da criação da democracia em Atenas, mostrando a monarquia/tirania como uma forma de governo pervertida, e a democracia por meio de um juízo valorativo positivo, em um contexto ateniense. Logo, ele cria dois modelos políticos antagônicos. É possível pensar que a biografia do autor ajuda, em parte, a justificar esse pensamento político. Além disso, Heródoto provavelmente sofria influências das discussões existentes em seu tempo, como o próprio debate acerca da efetividade de cada forma de governo. Píndaro, por exemplo, indica que esse devia ser um assunto recorrente nas póleis.

Em segundo lugar, o embate ideológico entre as diferentes constituições culmina no debate persa, no qual o autor indica uma tripla classificação das formas de governo ao mostrar a existência de governos monárquicos, oligárquicos e democráticos (governo de um, de poucos e da maioria, respectivamente). Nesse caso, monarquia e democracia, propostas por Dario e Otanes, simbolizam os pólos políticos opostos em discussão numa cisão ideológica entre centralização e descentralização política. O historiador, inclusive, demonstra nos antecedentes do debate persa que já havia uma tensão entre esses dois persas nos eventos que levaram à deposição do mago - o aquemênida sagrouse "vitorioso", uma vez que sua vontade prevaleceu ante à do rival. De certa forma, esse embate entre os dois constrói o caminho que os levaria a se confrontar ideologicamente no debate persa, novamente com a vitória de Dario. Por fim, a oligarquia proposta por Megabizo serviria como uma constituição intermediária entre a centralização e a distribuição de poder.

Isso por si só já nos permite afirmar que Heródoto pode ser classificado como um pensador político, e não apenas como historiador - embora não tenha sistematizado 
sua teoria sobre as formas de governo. No lugar disso, o autor optou por adotar a metodologia de levar o debate ao público por meio da reconstrução das supostas falas de Otanes, Megabizo e Dario, em III.80-82.

Contudo, a análise do debate persa por meio do suporte da filosofia política também nos permite afirmar que o fragmento apresenta outra possibilidade de análise, mais complexa, uma vez que depende de uma interpretação com base nos elementos implícitos no texto: a de que o historiador de Halicarnasso não trabalhava com uma tripla classificação das constituições, mas sim com uma hexa classificação. Isso é possível porque fica implícito em alguns trechos que Heródoto construiu uma teoria valorativa mais ampla acerca das formas de governo, de modo a dividi-las entre as boas e as más. Cada modelo - governo de um, de poucos e da maioria - é apresentado a partir de uma dupla classificação, tendo seus modelos positivo e negativo, com base no modo como o poder é empregado pelo governante.

A partir desta perspectiva, é possível afirmar que Otanes critica não um modelo monárquico de governo, mas sim sua contraparte ilegítima, ou seja, o governo tirânico. Em seguida, ele propõe a adoção de uma democracia. O segundo persa a falar, Megabizo, segue a argumentação de Otanes e critica a tirania, mas discorda do governo popular, tecendo críticas que o associam à oclocracia - a versão degenerada da democracia, na qual a hýbris das massas leva a pólis ao caos. Na sequência, Megabizo defende a adoção de uma aristocracia, ou seja, um governo composto por poucos indivíduos, cuja preocupação reside no melhor para a Pérsia. Por último, Dario questiona a eficiência da oclocracia e da oligarquia, e sugere a manutenção da monarquia como forma de governo da Pérsia, alegando que o melhor dos homens é o único capaz de ordenar a sociedade.

Deste modo, é possível notar que Heródoto não foge da lógica analítica que seria consagrada posteriormente por Aristóteles - analisar os governos de um, de poucos ou da maioria a partir de um juízo valorativo que os divide em dois grupos. Porém, o historiador não sistematizou a discussão, deixando algumas informações implícitas no texto. Uma das possibilidades é que na época de Heródoto ainda não havia uma tipologia específica para cada uma dessas constituições, o que tornava os termos muito fluidos. É por isso que em muitas ocasiões o próprio autor usa o termo tirania como sinônimo de monarquia, por exemplo. Esse, inclusive, era um problema comum aos autores do século VI a.C.. 
Sendo assim, a possibilidade de interpretarmos o fragmento III.80-82 a partir da leitura das seis formas de governo fortalece a hipótese de que Heródoto foi sim um pensador político, que seguiu uma tradição já existente, apresentou-a ao público de forma enunciativa pela primeira vez, e com isso deixou uma importante herança teórica para as gerações seguintes, que seria fundamental para que filósofos como Platão, Aristóteles, Políbio e Cícero (só para citar os antigos) pudessem elaborar seus trabalhos sobre as formas de governo nos séculos seguintes.

Por fim, cabe uma última consideração. O terceiro discurso, de Dario, apresenta um elemento implícito distinto das falas de Otanes e Megabizo: a ideia de que oclocracia e oligarquia produzem stásis, ou seja, conflito civil na pólis, e que o caos só pode ser superado com a ascensão de um governante único - o que ocorreria de forma natural, já que a instabilidade parece produzir uma situação na qual as constituições sofreriam transformações naturais, até atingirem um estágio de ordenamento. Deste modo, a oclocracia e a oligarquia gerariam problemas sociais e políticos; essas constituições se transformariam a partir da ascensão de um monarca ao poder, que por sua vez conseguiria levar ordem à comunidade política. Como já mencionado, essa ideia fica apenas sugerida no documento. Porém, se Heródoto e os homens da sua geração já conheciam a classificação das constituições, embora ainda não houvesse sido sistematizada, também é possível pensar que já existia algum tipo de discussão sobre a anaciclose.

Se tomarmos como verdadeira a premissa de que o fragmento III.82 apresenta um esboço ainda não completamente finalizado sobre o ciclo de constituições, podemos considerá-lo mais um argumento favorável à ideia de que Heródoto foi um pensador político sofisticado - embora não sistematizado. 


\section{Bibliografia}

\section{Heródoto}

HERODOTE. Histoires (vol. 1). Paris: Les Belles Lettres, 1946.

. Histoires (vol 2). Paris: Les Belles Lettres, 1948.

. Histoires (vol 3). Paris: Les Belles Lettres, 1949.

. Histoires (vol 4). Paris: Les Belles Lettres, 1949.

. Histoires (vol 5). Paris: Les Belles Lettres, 1946.

. Histoires (vol 6). Paris: Les Belles Lettres, 1948.

Histoires (vol 7). Paris: Les Belles Lettres, 1951.

Histoires (vol 8). Paris: Les Belles Lettres, 1953.

. Histoires (vol 9). Paris: Les Belles Lettres, 1954

HERÔDOTOS. História. Brasília: UnB, 1985.

HERODOTUS. Histories volume 1 (books I - II). Oxford: Loeb Classic Library, 1920.

Histories volume 2 (books III - IV). Oxford: Loeb Classic Library, 1921.

Histories volume 3 (books V - VII). Oxford: Loeb Classic Library, 1922.

Histories volume 4 (books VIII - IX). Oxford: Loeb Classic Library, 1925. 
Outras fontes

ARISTOTE. Politique: livres III-IV. Paris: Les Belles-Lettres, 1989, 12ª edição.

ARISTÓTELES. A constituição de Atenas, in: Os Pensadores: Aristóteles, São Paulo, Nova Cultura, 2004, p. 253-313. 2004, p. 141-251.

Política, in: Os Pensadores: Aristóteles, São Paulo, Nova Cultura,

ARISTOTLE. On the Constitution of Athens. Londres: Macmillan and Co., 1892.

KUHRT, Amélie. The Persian Empire: a corpus of sources from the Achaemenid period. Londres: Routledge, 2010.

LECOQ, Pierre. Les inscriptions de Darius I, in: Les inscriptions de la perse achéménide, Paris: Gallimard, 1997.

PÍNDAR. The Odes of Pindar. Oxford: Loeb Classic Library, 1915.

PLATON. Oeuvres complètes: la République (tome VIII). Paris: Les Belles Lettres, 1934.

POLYBIUS. The Histories: vol. III. Cambridge: Harvard University Press, 1954.

PLUTARCO. Da Malícia de Heródoto. São Paulo: EdUSP, 2013.

TUCÍDIDES. História da Guerra do Peloponeso. Brasília: UnB, 1987.

História da Guerra do Peloponeso. São Paulo: Martins Fontes, 2008. 
Obras de referência

BOARDMAN, J.; LEWIS, D.M.; HAMMOND, N.G.L.; OSTWALD, M. (editores). The Cambridge Ancient History vol. 4: Persia, Greece and the Western Mediterranean. Cambridge: Cambridge University Press.

BOBBIO, Norberto; MATTEUCCI, Nicola; PASQUINO, Gianfranco. Dicionário de Política. Brasília: Editora UnB, 1998.

WEFFORT, Francisco. Os clássicos da política - volume 1. São Paulo: Ática, 2004, $1^{\text {a }}$ ed.

ed.

Os clássicos da política - volume 2. São Paulo: Ática, 2004, $1^{\text {a }}$ 


\section{Livros e artigos}

ASHERI, David. Book III, in: ASHERI, David; CORCELLA, Aldo; LLOYD, Alan. A commentary on Herodotus books I-IV. Oxford: Oxford University Press, 2007.

. O Estado persa. São Paulo: Perspectiva, 2006.

BAGHBIDI, Hassan Rezai. Darius and the Bisotun Inscription: a new interpretation of the last paragraph of column IV, in: Journal of Persianate Studies, vol. 2, 2009, p. 44-61.

BAIKEY, Neils. Early Mesopotamian Constitutional development, in: The American Historical Review, vol. 72, n. 4, 1967.

BAKER, Ernest. Teoria política grega. Brasília: UnB, 1978.

BARAGWANATH, Emily. Motivations and narrative in Herodotus. Oxford: Oxford University Press, 2008.

BLOCH, Marc. Apologia da História. Rio de Janeiro: Jorge Zahar, 2002.

BOBBIO, Norberto. A teoria das formas de governo. Brasília: editora UnB, 1985, $10^{a}$ edição.

BOEDEKER, Deborah. Early Greek poetry Asian history, in The Oxford History of Historiography Writing, Oxford: Oxford University Press, 2011, vol. 1, p. 122147.

BRANNAN, Patrick T. Herodotus and History: the constitutional debate preceding Darius' accession, in: Traditio, vol. 19, 1963.

BRIANT, Pierre. From Alexander to Cyrus : a history of the Persian Empire. Winona Lake: Eisenbrauns, 2002.

BRINK, C. O.; WALBANK, F. W. The construction of the sixty book of Polybius, in: The Classical Quarterly, vol. 4, n. 3/4, 1954, p. 97-122.

BUTTI DE LIMA, Paulo. Teria o Oriente inventado a democracia?, in: Goiania, Revista UFG, n. 4, 2008, p. 1-4.

CHÂTELET, François; DUHAMEL, Olivier; PISIER-KOUCHNER, Évelyne. História das ideias políticas. Rio de Janeiro: Zahar Editor, 1994. 
CHRIST, Matthew R. Kings and historical inquery, in: Classical Antiquity, vol. 13, n. 2, 1994, p. 167-202.

CONDILO, Camila da Silva. Heródoto, as tiranias e o pensamento político nas Histórias. São Paulo: Anna Blume, 2010, $1^{\text {a }}$ edição.

DALlARI, Dalmo de Abreu. Elementos da Teoria Geral do Estado. São Paulo: Saraiva, 1995.

DARBO-PESCHANSKI, Catherine. O discurso do particular: ensaio sobre a investigação de Heródoto. Brasília: Editora UnB, 1998.

DEMONT, Paul. Le nomos-roi: Hérodote, III, 38, in: Hérodote: formes de pensée, figures du récit. Rennes: Presses universitaires de Rennes, 2013, p. 37-45.

DEWALD, Carolyn. The archaic smile of Herodotus by Stewart Flory - review, in: Classical Philosophy, vol. 85, n. 1, 1990, p. 60-64.

DUMÉZIL, Georges. L'intronisation de Darius, in: E.J. Brill, vol. 1, 1984, p. 143149.

EHRENBERG, Victor. Origins of democracy, in: Franz Steiner Verlag, 1950, p. 515548.

EVANS, J.A.S. Herodotus, explorer of the past. New Jersey: Princeton University Press, 1991.

Notes on the debate of the Persian grandees in Herodotus 3, 80-82. Quaderni Urbinati di Cultura Classica, New Series, vol. 7, p. 79-84, 1981.

FERREIRA, Moisés Olímpio. A lírica grega arcaica: Arquíloco de Paros - estudo do fr. 19, in: Alétheia - Revista de estudos sobre a Antiguidade e Medievo, vol. $1,2009$.

FINLEY, Moses. História Antiga: testemunhos e modelos. São Paulo: Martins Fontes, 1994. Press, 1983.

Politics in the Ancient Word. Cambridge: Cambridge University

FLORY, Stewart. The archaic smile of Herodotus. Detroit: Wayne State University Press, 1987. 
The personality of Herodotus, in: Arion, Boston: Trustees of Boston University, vol. 8, n. 1, p. 99 - 109, 1969.

. Who read Herodotus' Histories?, in The American Journal of Philology, Baltimore: The John Hopkins University Press, vol. 101, n. 1, p. 12 28, 1980 .

FORDSDYKE, Sara. Athenian democratic ideology and Herodotus' Histories, in: American Journal of Philology, vol. 122, n. 3, 2001, p. 329-358.

From aristocratic to democratic ideology and back again: the Thrasybulus anedocte in Herodotus' Histories and Aristotle's Politics, in: Classical Philology, vol. 94, n. 4, 1999, p. 361-372.

GAMMIE, John. Herodotus on kings and tyrants: objective historiography or conventional portraiture?, in: Journal of Near Eastern Studies, 1986, v. 45, n. 3, p. 171-195.

GEHRKE, Hans-Joachim. Myth, history, politics - ancient and modern, in: Greek and Roman Historiography, Oxford: Oxford University Press, 2011.

GOMME, A.W. Pericles monarchos, in: The Journal of Helenic Studies, vol. 70, p. 76-77, 1950.

GOUSCHIN, Valerij. Pisistratus leadership in A.P. 13.4 and the establishment of the tyranny of 561/60 BC, in: The Classical Quarterly, vol. 49, n. 1, 1999, p. 1423.

GRAY, Vivienne. Herodotus and images of tyranny: the tyrants of Corinth, in: The American Journal of Philology, vol. 117, n. 3, 1996, p. 361-389.

Herodotus' literary and historical method: Arion' story (I.23-24), in: The American Journal of Philology, 2001, v. 112, p. 11-28.

GRETHLEIN, Jonas. The rise of Greek historiography and the invention of prose, in The Oxford History of Historiography Writing, Oxford: Oxford University Press, 2011, vol 1, p. 148-170.

GRUEN, Erich. Rethinking the other in antiquity. Princeton University Press, 2011.

GUARINELLO, Norberto Luiz. História Antiga. São Paulo: Contexto, 2013.

HALL, Jonathan. Ethnic identity in Greek antiquity. Cambridge University Press, 1997. 
HANSEN, Mogens Herman. Pólis: an introduction to the Ancient Greek city-state. New York: Oxford University Press, 2006.

. The tradition of the Athenian democracy A.D. 1750-1990, in: Greece \& Rome, vol. 39, n. 1, 1992, p. 14-30.

HARTOG, François. O espelho de Heródoto. Belo Horizonte: Editora UFMG, 1999.

HERING, Fabio. Atenas e Némesis. Acerca da lógica investigative e da unidade discursive nas Histórias de Heródoto. In: Varia Historia, 2004, n. 31, p. 209220.

HIRATA, Elaine. As odes de Píndaro e as tiranias siciliotas, in: Clássica, 1996/1997, v. $9 / 10$, p. 61-72.

HUTTON, Maurice. The mind of Herodotus, in: Transactions and proceeding of the American Philological Association, vol. 42, p. 33-43. The John Hopkins University Press, 1911.

IMMERWAHR, Henry. Form and thought in Herodotus. Atlanta: Scholars Press, 1986.

IRIARTE, Ana. Despotisme et modes de communication: de l'enquête tragique au drame hérodotéen, in: Hérodote: formes de pensée, figures du récit, Rennes: Presses Universitaires de Rennes, 2013, p. 95-116.

KURY, Mário da Gama (trad.). História. Brasília: UnB, 1988.

1987.

História da Guerra do Peloponeso. Brasília: UnB,

LATEINER, Donald. The historical method of Herodotus. Toronto: University of Toronto Press, 1989.

LE GOFF, Jacques. Monumento/Documento. In: História e Memória. São Paulo: Editora da Unicamp, 2003. 525-541.

LESSERRE, F. L'historiographie grecque à époque archaique, in: Quaderni di Storia, n. 4, 1976, p. 113-143. 
LEVORIN, Paulo. A república dos antigos e a república dos modernos. Tese de doutorado defendida no Departamento de Ciência Política da Universidade de São Paulo, São Paulo, 2001.

LEVY, Edmond. Basileus et turannos chez Hérodote, in: Ktema. Civilisations de l'Orient, de la Grèce et de Rome antiques, 1993, n. 18, p. 7-18.

MARINCOLA, John. Introduction, In: Greek and Roman History. Osford: Oxford University Press, 2011.

MCGLEW, James F. Tyranny and political culture in Ancient Greece. Londres: Cornell University Press, 1993.

MENESES SOUSA, Paulo Ângelo de. Memória histórica e narrativa em Heródoto, in: Humanitas, 2009, vol. 61, p. 83-106.

EdUFPI, 2010.

O debate persa em Heródoto. Teresina:

MOMIGLIANO, Arnaldo. La historiografía Griega. Barcelona: Editorial Crítica, 1984.

. La place d'Hérodote dans l'histoire de l'historiographie, in: Problèmes d'historiographie ancienne et moderne. Paris: Gallimard, 1983, p. 169-185.

MORRISON, J.S. Pericles monarchos, in: The Journal of Helenic Studies, vol. 70, p. 76-77, 1950.

MOSSÉ, Claude. As instituições gregas. Lisboa: Edições 70, 1970.

Histoire d'une démocratie: Athènes - Des origines à la conquête macédonienne. Paris: Éditions du Seuil, 1971.

MURARI PIRES, Francisco. Mithistória do debate persa, in: História da Historiografia, São Paulo, 2012, 10, p. 183-192.

MURRAY, Oswyn. Greek historians, in: The Oxford History of Greece and the Hellenistic World, Oxford: Oxford University Press, 1988, p. 214-239.

MEYERS, Richard. La démocratie chez Hérodote: une étude du débat sur les régimes, in: Revue Canadienne de Science Politique, v. 24, n. 3, 1991, p. 541555. 
OLMSTEAD, A.T. History of Persian Empire. Chicago: University of Chicago Press, 1948.

OOST, Stewart Irving. The tyrants kings of Siracuse, in: Classical Philology, 1976, v. 71, n. 3, p. 224-236.

PAYEN, Pascal. Hérodote et Lévi-Strauss: questions d'ethnographie, In: Hérodote: formes de pensée, figures du récit, Rennes: Presses Universitaires de Rennes, 2013, p. 179-196.

PEELING, Christopher. Speech and action: Herodotus' debate on the constitutions, in: Proceeding of the Cambridge Philological Society, 48, 2002, p. 123-158.

RANKE, Leopold von. Heródoto e Tucídides, in: História da historiografia. Ouro Preto, n. 6, março 2011, p. 252-259.

REDFIELD, James. Herodotus the tourist, in: Greeks and Barbarians, NY: Routledge, 2002, p. 24-49.

ROCHA MENEZES, Luiz Maurício Bentim da. Nova interpretação da passagem 359d da República de Platão, in: Kriterion: Revista de Filosofia, vol. 53, n. 125, 2012.

ROMILLY, Jaqueline. Le classement des constitutions d'Hérodote a Aristote, in: Revue d'Études Grecques, n. 72, p. 81-99, 1959.

ROMM, James. Herodotus. New Haven: Yale University Press, 1998.

ROY, Sydnor. The constitucional debate: Herodotus' exploration of good government, in: Histos, vol. 6, 2012, p. 298-320.

SÁNCHEZ, Manoel García. El gran Rey de Persia: formas de representación de la alteridad persa en el imaginario griego. Barcelona: Publicacions i Edicions UB, 2009.

SCHMIDT, Erich. Persepolis I: structures, reliefs, inscriptions. Chicago: University of Chicago Press, 1953.

Persepolis III: the royal tombs and other monuments. Chicago: University of Chicago Press, 1970.

SCHNEIDER, Jens. Discursos simbólicos e símbolos discursivos: considerações sobre a etnografia da identidade nacional, in: Mana, n. 10, vol. 1, 2004, p. 97-129. 
SEALEY, Raphael. The origins of "demokratia", in: California Studies in Classical Antiquity. California: California University Press, 1973, vol. 6, p. 253-295.

SHIELDS, Christopher. Aristotle. London: Routledge, 2007.

TAYLOR, C.C.W. Politics, in: BARNES, Jonathan (ed.). The Cambridge Companion to Aristotle. Cambridge: Cambridge University Press, 1995, p. 233-258.

THOMAS, Rosalind. Oral tradition and and written record in Classical Athens. Cambridge: Cambridge University Press, 1989.

THOMPSON, Norma. Herodotus and the origins of the political community. New Haver: Yale University Press, 1996.

VERNANT, Jean-Pièrre, VIDAL-NAQUET, Pièrre. Mito e tragédia na Grécia Antiga. São Paulo: Perspectiva, 2008.

VLASSOPOULOS, Kostas. Greeks and barbarians. Cambridge: Cambridge University Press, 2013.

University Press, 2007.

Unthinking the Greek Pólis. Cambridge: Cambridge

WARD, Anne. Herodotus and the philosophy of Empire. Waco: 2008.

WATERS, H.K. Herodotus on tyrants and despots: a study on objectivity. Wiesbaden: Steiner, 1971.

Heródoto el historiador: sus problemas, métodos y originalidad. México: Fondo de Cultura Económica, 1996.

WELLS, J. Hedodotus and Athens, in: Classical Philology, vol. 23, n. 4, 1928, p. $317-$ 331.

ZIMMERN, A.E.. Political thought, in: The legacy of Greece. Oxford: Oxford University Press, 1951, p. 321-352. 


\section{Anexos}

\section{Documentos utilizados no terceiro capítulo (Hist., III.80-82)}

\section{Anexo A \\ Edição Les Belles Lettres}

III.80. Lorsque le tumulte fut clamé et qu'il se fut écoulé cinq jours, ceux qui s'étaient soulevés contre les mages délibérèrent sur l'emsemble de la situation; et des discours furent tenus que certains des Grecs trouvent incroyables, mais qui furent tenus cependant.

Otanès engageait à remettre à la disposition de tous les Perses la direction des affaires ; el disait : «Mon avis est qu'un seul homme n'ait plus sur nous d'autorité monarchique ; car cela n'est ni agréable ni bon. Vous avez vu en effet à quel point s'est porté l'insolent orgueil de Cambyse, et vous avez pour votre part éprouvé aussi celui du mage. Comment la monarchie serait-elle chose bien ordonné, quand il lui est loisible, sans avoir de comptes à rendre, de faire ce qu'elle veut ? Le meilleur homme du monde, investi de cette autorité, serait en effet mis par elle hors de ses pensers accoutumés. La prospérité dont il jouit fait naître en lui l'insolence orgueilleuse ; et l'envie est innée chez l'homme de tout temps. Ayant ces deux vices, le monarque a en lui toute méchanceté : l'orgueil fait que, gorgé, il commet beaucoup d'actes follement criminels ; l'envie de même. En vérité, le tyran, mieux qu'un autre, devrait ignorer l'envie, puisqu'il possède tous les biens ; mais c'est tout le contraire qu'exprime son attitude envers les citoyens : il envie les meilleurs tant qu'ils vivent et sont de ce monde ; il est bien avec la pire partie de la population, il est très fort pour accueillir les calomnies. Rien de plus inconséquent : si vous l'admirez modérément, il vous en veut de ne pas le beaucoup courtiser ; le courtise-t-on beaucoup, il vous en veut comme à un vil flatteur. Et je vais dire ce qu'il y a de plus grave : il bouleverse les coutumes des ancêtres, il fait violence aux femmes, il met à mort sans jugement. Au contraire, le gouvernement du peuple, tout d'abord, porte le plus beau de tous le noms : isonomie. Puis, il ne s'y fait rien de ce que fait le monarque : on y obtient les magistratures par le sort, on y rend compte de l'autorité qu'on exerce, toutes les délibérations y sont soumises au public. J'opine donc pour que nous renoncions à la monarchie et que nous élevions le peuple au pouvoir ; car c'est dans le nombre que tout réside. » 
III.81. Telle était l'opinion que présenta Otanès. Mais Mégabyze voulait que l'ont confiât les affaires à une oligarchie ; il disait : «Ce qu'a dit Otanès conseillant d'abolir le régime tyrannique, tenez-le pour dit par moi aussi ; mais, quand il vous pressait de déférer au peuple le pouvoir, il s'est écarté de l'avis le plus sage. Car il n'est rien de plus insolent qu'une multitude bonne à rien. Et, à coup sûr, échapper à l'insolence d'un tyran pour choir dans celle d'une populace effrénée est chose qu'on ne saurait aucunement tolérer. L'un, s'il fait quelque chose, le fait en connaissance de cause ; l'autre n'est pas même capable de cette connaissance. Comment en effet l'aurait-elle, n'ayant pas reçu d'instruction ni rien vu de bien par elle-même, bousculant les affaires òu elle se jette sans réflexion, pareille à un fleuve torrentueux ? Que ceux qui veulent du mal aux Perses, que ceux-là donc usent de la démocratie ; mais nous, choisissons un groupe d'hommes parmi les meilleurs, et investissons-les du pouvoir ; car, certes, nous serons nous-mêmes de leur nombre, et il est dans l'ordre de la vraisemblence que les hommes les meilleurs prennet les meilleurs décisions. »

III.82. Telle était l'opinion que présenta Mégabyze. Le troisième, Darius exposa son avis, en ces termes : «Pour moi, ce qu'a dit Mégabyze concernant le régime populaire me paraît avoir été bien dit, mais non pas ce qui concernait l'oligarchie. Des trois régimes qui s'offrent à nous, tous les trois étant par hypothèse aussi bons que possible, démocratie aussi bonne que possible, oligarchie de même et régime monarchique, j'affirme que ce dernier l'emporte de beaucoup. Rien ne saurait se montrer préférable à un gouvernant unique, s'il est le meilleur ; ayant des pensées à sa mesure, il peut exercer sur le peuple une tutelle irrépréhensible; et c'est avec lui que peuvent le mieux être tenues secrètes les décisions qui visent les ennemis. Dans l'oligarchie, entre plusieurs hommes qui déploient leur mérite pour l'intérèt commun, l'habitude est qu'il naisse de violentes inimitiés personneles ; car, chacun voulant être le chef et faire triompher ses opinions, ils en viennent à se détester fortement les uns les autres; des inimitiés naissent les discordes, des discordes les meurtres, et les meurtres aboutissent à la monarchie ; ce qui montre combien ce dernier régime est le meilleur. Lorsque c'est au contraire le peuple qui a le pouvoir, il est inévitable que la méchanceté se développe ; or, quand la méchanceté se développe dans le domaine des choses publiques, ce ne sont pas des inimitiés qui naissent entre les méchants, mais de violentes amitiés ; car ceux qui mettent l'état à mal le font en complotant entre eux. Il en est ainsi jusqu'au moment où 
un homme, s'étant fait le protecteur du peuple, met fin à leurs agissements ; cet homme, en conséquence, est admiré par le peuple ; et, admiré, il est proclamé monarque ; en quoi son cas aussi prouve que la monarchie est ce qu'il y a de mieux. Et, pour tout dire en un mot, d'où nous est venue la liberté ? Qui nous l'a donnée ? Est-ce le peuple, l'oligarchie, ou bien la monarchie ? Je suis donc d'avis que, libérés grâce à un seul homme, nous conservions le gouvernment d'un seul ; et, indépendamment de cela, que nous ne renversions par les institutions de nos pères quand elles sont solides; il n'y aurait pas avantage. » 


\section{Anexo B}

Edição The Loeb Classical Library

III. 80. When the tumult was abated, and five days has passed, the rebels against the Magians held a council on the whole state of affairs, at which words were uttered which to some Greeks seem incredible; but there is no doubt that they were spoken. Otanes was for giving the government to the whole body of the Persians people. "I hold," he said, "that we must taken an end of monarchy; there is no pleasure or advantage in it. You have seen to what lengths went the insolence of Cambyses, and you have borne your share of the insolence of the Magian. What right order is there to be found in monarchy, when the ruler can do what he will, nor be held to account for it? Give this power to the best man on earth, and it would stir him to unwonted thoughts. The advantage which he holds breeds insolence, and nature makes all men jealous. Thus double cause is the root of all evil in him; sated with the power he will do many reckless deeds, some from insolence, some for jealousy. For whereas an absolute ruler, as having all that heart can desire, should rightly be jealous of no man, yet it is contrariwise with him in his dealing with his countrymen; he is jealous of the safety of the good, and glad of the safety to the evil; and no man is so ready to believe calumny. Of all men he is the most inconsistent; accord him but just honour, and he is displeased that you make him not your first care; make him such, and he damns you for a flatterer. But I have yet worse to say of him than that; he turns the laws of the land upside down, he rapes women, he puts high and low to death. But the virtue of a multitude's rule lies first in its excellent name, which signifies equality before the law; and secondly, in that it does none of the things that a monarch does. All offices are assigned by lot, and the holders are accountable for what they do therein; and the general assembly arbitrates on all counsels. Therefore I declare my opinion, that we make an end of monarchy and increase the power of the multitude, seeing that all good lies in the many."

III.81. Such the judgment of Otanes: but Megabyzus' counsels was to make a ruling oligarchy. "I agree," said he, "to all that Otanes says against the rule of one; but when he bids you give the power to the multitude, his judgment falls short of the best. Nothing is more foolish and violent than a useless mob; to save ourselves from the insolence of a despot by changing it for the insolence of the unbridled commonalty that were unbearable indeed. Whatever the despot does, he does with knowledge; but 
the people have not even that; how can they have knowledge, who have neither learnt nor for themselves seen what is best, but ever rush headlong and drive blindly onward, like a river in spate? Let those stand for democracy who wish ill to Persia; but let us choose a company of the best men and invest these with the power. For we ourselves shall be of that company; and where we have the best men, there "tis like that we shall have the best counsels."

III.82. Such was the judgment of Megabyzus. Darius was the third to declare his opinion. "Methinks," said he, "Megabyzus speaks rightly concerning democracy, but not so concerning oligarchy. For the choice lying between these three, and each of them, democracy, oligarchy and monarchy being supposed to be the best of its kind, I hold the monarchy is by far the most excellent. Nothing can be found better than the rule of one best man; his judgment being like do himself, he will govern the multitude with perfect wisdom, and best conceal plans made for the defeat of enemies. But in an oligarchy, the desire of many to do the state good service overtimes engenders bitter enmity among them; for each one wishing to be chief of all and to make his counsels prevail, violent enmity is the outcome, enmity brings faction and faction bloodshed; and the end of bloodshed is monarchy; whereby it is shown that this fashion of government is the best. Again, the rule of the commonalty must of necessity engender evil-mindedness; and when evil-mindedness in public matters is engendered, bad men are not divided by enmity but united by close friendship; for they that would do evil to the commonwealth conspire together to do it. This continues till someone rises to champion the people's cause and makes an end of such evil-doing. He therefore becomes the people's idol, and being their idol is made their monarch; so his case also proves that monarchy is the best government. But (to conclude the whole matter in one word) tell me, whence and by whose gift our freedom - from the commonalty or an oligarchy or a single ruler? I hold therefore, that as the rule of one man gave us freedom, so that rule we should preserve; and, moreover, that we should not repeal the good laws of our fathers; that were ill done." 


\section{Anexo C}

Edição UnB (com tradução de Mário da Gama Kury)

III.80. Quando cessou o tumulto, passados cinco dias, os persas rebelados contra os magos se reuniram em conselho para tratar da situação em geral, e pronunciaram discursos considerados incríveis por alguns helenos, mas eles foram realmente pronunciados. Otanes pleiteou a entrega do governo ao povo persa, dizendo o seguinte: "Em minha opinião o governo não deve caber a um único homem; isso nem é agradável nem é bom. Vistes a que extremos chegou a insolência de Cambises, e suportastes também a insolência do mago. Como seria possível haver equilíbrio no governo de um homem só, se nele o governante pode fazer o que lhe apraz e não tem de prestar contas de seus atos? Dê tal autoridade ao melhor de todos os homens e ele será levado por ela a abandonar o seu modo normal de pensar. $\mathrm{O}$ desejo de fruir dos bens presentes gera a insolência, e a natureza fez os homens invejosos desde a sua origem. Essas duas causas se acham na raiz de toda a maldade humana; repletos ora de orgulho, ora de inveja, eles cometerão desvairadamente muitos crimes. Um tirano, todavia, tendo tudo que quer deveria desconhecer a inveja, mas está em sua natureza fazer o contrário em relação aos seus concidadãos: ele tem inveja da maneira de conduzir-se e de viver dos homens de bem, e se compraz com os piores de todos os cidadãos; e ninguém acolhe as calúnias melhor que ele. Ele é o mais inconsequente de todos os homens; se alguém se mostra comedido em seus louvores, ele fica transtornado por estar lidando com um adulador. Mas ainda vou dizer o maior de seus defeitos: ele subverte os costumes ancestrais, violenta mulheres e condena as pessoas à morte sem mandar julgá-las. O governo do povo, ao contrário, traz primeiro consigo o mais belo de todos os nomes: igualdade perante a lei, e em segundo lugar, nenhuma das injustiças cometidas por um governante único é cometida nele. Todas as funções são atribuídas através de sorteio, e seus detentores são responsáveis pelos atos praticados no exercício das mesmas, e todas as decisões são submetidas à assembléia popular. Exponho portanto a minha opinião, propondo que acabemos com o governo de um único homem e elevemos o povo ao poder, pois tudo está na maioria."

III.81. Essa foi a opinião de Otanes. Em seguida Megabizo propôs a instituição de uma oligarquia, dizendo o seguinte: “Quando Otanes propõe a extinção do governo de um único homem, concordo com suas palavras, mas quando vos exorta a entregar o poder 
ao povo ele se afasta da melhor opinião. Nada é mais insensato e insolente que uma multidão indolente; salvar-nos da insolência de um tirano trocando-a pela insolência de uma multidão desenfreada seria absolutamente inadmissível. O tirano faz tudo sabendo o que faz, mas o povo nem isso sabe; e como saberia se não aprendeu de outros nem sabe ver por si mesmo o que é melhor, e se lança de cabeça baixa aos assuntos, avançando cegamente, como um rio na enchente? Deixemos o regime popular para quem deseja o mal dos persas, e escolhamos um grupo dos melhores homens e entreguemos-lhe o poder; nós mesmos estaremos entre eles, e é natural esperar dos melhores homens as melhores decisões."

III.82. A opinião de Megabizo foi essa. Dario emitiu a sua opinião em terceiro dizendo: "Para mim, as palavras de Megabizo a respeito do regime popular parecem bem ditas, mas quanto à oligarquia ele não falou acertadamente. Com efeito, dos três regimes que se nos oferecem, teoricamente cada um deles é o melhor possível - o regime popular é excelente, a oligarquia também e o governo de um único homem também; digo, então, que o governo de um homem só é de longe o melhor. Nada parece preferível ao governo de um homem só, se este é o melhor dos homens; sendo seu povo, e jamais alguém guardará melhor os planos para derrotar o inimigo do que esse homem. Mas numa oligarquia o fato de várias pessoas desejarem pôr o seu talento a serviço da coisa pública gera constantemente profundas divergências entre elas; como cada uma delas quer ser o condutor do grupo e quer fazer prevalecer a sua opinião, o resultado é a inimizade exacerbada; a inimizade gera dissensões e as dissensões geram derramamento de sangue, e do derramamento de sangue emerge o governo de um único homem; logo, isso prova qual regime é o melhor. Por outro lado, entregando-se o poder ao povo é impossível evitar a eclosão da incompetência; e quando há incompetência na administração da coisa pública, os homens maus não são levados à divisão pela inimizade; eles se unem numa amizade solidária, pois as pessoas são capazes de prejudicar a comunidade entram em conluio para prejudicá-las juntas. Essa situação se prolonga até aparecer alguém como paladino do povo para pôr fim a tal incompetência; então essa pessoa conquista a admiração do povo, e assim admirada emerge como um governante único; isso evidencia também que o governo de um homem só é o melhor. Mas dizendo tudo em poucas palavras para concluir, de onde nos veio a nossa liberdade e a quem a devemos? Do governo popular, da oligarquia ou do governo de um único homem? Sustento portanto que, libertos graças a um único homem, devemos preservar 
o governo de um único homem; além disso, não devemos abolir as instituições de nossos antepassados se elas funcionam bem; isso não seria melhor." 